GLOBAL WATER PATHOGEN PROJECT

PART THREE. SPECIFIC EXCRETED PATHOGENS: ENVIRONMENTAL AND EPIDEMIOLOGY ASPECTS

\title{
POLIOVIRUSES AND OTHER ENTEROVIRUSES
}

\author{
Walter Betancourt \\ University of Arizona \\ Tucson, United States
}

Lester Shulman

Tel Aviv University

Tel Aviv, Israel 


\section{Copyright:}

\section{cc) (i) (2) \\ BY SA}

This publication is available in Open Access under the Attribution-ShareAlike 3.0 IGO (CC-BY-SA 3.0 IGO) license (http://creativecommons.org/licenses/by-sa/3.0/igo). By using the content of this publication, the users accept to be bound by the terms of use of the UNESCO Open Access Repository (http://www.unesco.org/openaccess/terms-use-ccbysa-en).

\section{Disclaimer:}

The designations employed and the presentation of material throughout this publication do not imply the expression of any opinion whatsoever on the part of UNESCO concerning the legal status of any country, territory, city or area or of its authorities, or concerning the delimitation of its frontiers or boundaries. The ideas and opinions expressed in this publication are those of the authors; they are not necessarily those of UNESCO and do not commit the Organization.

\section{Citation:}

Betanourt, W.Q., and Shulman, L.M. (2017). Polioviruses and other Enteroviruses. In: J.B. Rose and B. JiménezCisneros, (eds) Water and Sanitation for the 21st Century: Health and Microbiological Aspects of Excreta and Wastewater Management (Global Water Pathogen Project). (J.S Meschke, and R. Girones (eds), Part 3: Specific Excreted Pathogens: Environmental and Epidemiology Aspects - Section 1: Viruses), Michigan State University, E. Lansing, MI, UNESCO. https://doi.org/10.14321/waterpathogens.15

Acknowledgements: K.R.L. Young, Project Design editor; Website Design: Agroknow (www.agroknow.com)

Last published: April 28, 2017 


\section{Summary}

Enteroviruses (EVs), including poliovirus and nonpolio enteroviruses (i.e., coxsackieviruses, echoviruses, enteroviruses) are among the most common genera of the Picornaviridae family that infect humans and therefore are known to circulate widely in human populations throughout the world. New genera of the Picornaviridae family (i.e., Saffold cardiovirus [SAFV]) Cosavirus [common stoolassociated picornavirus] Salivirus [stool Aichi-like virus]) have been identified in fecal specimens and wastewaters using conventional and highly-sensitive genomic sequencing technologies. In addition, members of the Echovirus genus originally known as echovirus 22 and 23 have been reclassified within the genus Parechovirus. Likewise, previous rhinovirus species have been reclassified within the Enterovirus genus. Enterovirus (EV) infections are a significant cause of morbidity and mortality throughout the world, primarily in infants and young children. Nevertheless, reliable worldwide estimates of EVrelated mortality are not currently available.

Enteroviruses like most enteric viruses have evolved stability to adverse environmental conditions, including thermal stability, acid stability, resistant to radiation as well as to oxidants and proteolytic enzymes, which allow survival of these viruses in the environment and facilitate their transmission through multiple environmental routes (e.g., water, food, aerosols, and virus-contaminated inanimate objects or fomites). Human wastes, such as sewage and poorly treated effluents, urban stormwater and combined sewers overflows (CSO) are the primary source of enteroviruses released into aquatic and land environments that subsequently contaminate raw source waters for potable supply, bathing waters, shellfish waters, and waters used for irrigation of crops. Groundwater sources are also vulnerable to contamination with enteroviruses through different routes including direct injection of wastes through wells, percolation of sewage sprayed over the land, leaking or broken sewer lines, seepage from waste lagoons, infiltration of sewage-polluted surface streams, and septic tank effluents. The biophysical properties of enteroviruses (i.e., small-size, genome type and the non-enveloped capsid structure of the virion) play an important role on virus survival in the environment and on the physical removal and inactivation of virus particles through conventional wastewater treatment processes. Membrane bioreactor systems (MBRs) are becoming increasingly applied in developed regions as advanced wastewater treatment technologies to produce treated effluents of very high quality applicable to wastewater discharge and recycling solutions, including non-potable or indirect potable reuse. The distribution and persistence of enteroviruses in sewage-polluted waters may vary geographically depending on the epidemiological status of the population, population density, and the extent of sanitation coverage (i.e., wastewater treatment and wastewater disposal) which influence the viral load released into the environment. Recent estimates by the World Health Organization (WHO)/United Nations Children's Fund (UNICEF) Joint Monitoring Programme for
Water Supply and Sanitation indicate that despite significant progress on sanitation, in 2012, more than one third of the global population - some 2.5 billion people - do not use an improved sanitation facility, and of these 1 billion people still practice open defecation. Sewage represents a useful matrix to derive information on circulating enteroviruses in given populations and to describe the enterovirus epidemiology associated with human disease, also known as environmental surveillance.

Environmental poliovirus surveillance is a major goal of the WHO Global Poliovirus Eradication Initiative (GPEI) used to monitor pathways of poliovirus transmission of wild poliovirus and circulating vaccine-derived polioviruses (cVDPVs). A major effort to develop new, improved, and safer live polio vaccine is being promoted by the WHO, Rotary and the Bill \& Melinda Gates Foundation. Human enteroviruses have been recovered worldwide from surface waters including coastal waters, rivers streams, and lakes, from ground waters, wastewaters and finished drinking water. Numerous methodological approaches have been recently developed for concentration of human enteric viruses from water and their isolation from the environment. Selection of an appropriate filtration method for the primary concentration of viruses is crucial to successful virus detection. However, an efficient method to recover all viruses has not been developed yet. Integrated cell culture and PCR (ICC-PCR) developed in the late 1980s is still applicable for detection and identification of a suite of infective viral pathogens recovered from environmental samples. The detection of enteroviruses in sources of drinking water and recreational water bodies has been broadly accepted as a marker of a possible failure of the sanitation systems and as an indicator of the potential role of water in disease outbreaks. Moreover, since the natural host for all human enteroviruses is humans, the detection and quantification of amplifiable enterovirus genetic material in environmental waters has been proposed and successfully used as a water quality assessment tool for tracking sources of human fecal pollution.

\section{Enteroviruses and new genera within the family Picornaviridae}

\subsection{Epidemiology of the Disease and Pathogen}

Human EVs, like all viruses, are obligate intracellular parasites that are dependent upon living host cells for the essential elements of replication (Lees, 2000). EVs including poliovirus (PV) and non-polio enteroviruses (NPEVs) (i.e., coxsackieviruses, echoviruses, EVs) are among the most common genera of the Picornaviridae family that infect humans and therefore are known to circulate widely in human populations throughout the world (Pallansch et al., 2013). Picornaviridae is considered one of the oldest and most diversified virus families, presenting a non-enveloped, single, positive-stranded RNA (ssRNA) genome packed in a $\sim 30 \mathrm{~nm}$ icosahedral capsid (Racaniello, 2013). This family includes many important enteric human and animal pathogens, such as poliovirus, hepatitis A virus, 
and foot-and-mouth-disease virus (Pallansch et al., 2013; Racaniello, 2013; Tapparel et al., 2013). Most EVs and other genera of enteric picornaviruses (Hepatovirus, Parechovirus, Cardiovirus, Kobuvirus, Salivirus, and Cosavirus) replicate in the epithelial cells of the gastrointestinal tract and their progeny are in fecal matter excreted into the environment.

\subsection{Global Burden of Disease}

\subsubsection{Global distribution}

Although enterovirus infections are a significant cause of morbidity and mortality throughout the world, in particular for infants and young children, reliable worldwide estimates of EV-related mortality are not currently available. Since enterovirus infections are not nationally notifiable and health authorities in different countries admit that these infections are never treated or tested, the number of enterovirus detections is likely a considerable underestimate of the true burden of disease. In the developed world, enterovirus infections result in hundreds of thousands of hospitalizations per year, with aseptic meningitis accounting for the vast majority of these cases. Enteroviral infections are more common in most developing countries, so it is reasonable to assume that significant morbidity can be attributed to these viruses globally (Pallansch et al., 2013). The disease burden in the developing world of the tropics is poorly estimated, with the exception of poliomyelitis. Indeed, the focus for the worldwide EV surveillance network is primarily on neurological presentation such as acute flaccid paralysis (AFP), to support poliovirus eradication programs. In general, national laboratories throughout the world report enterovirus typing results from clinical specimens to exclude poliovirus and establish the epidemiology of NPEVs. The World Health Organization (WHO) and the U.S Centers for Disease Control and Prevention (CDC) have guidelines for epidemiologic, clinical, and laboratory investigations of AFP to rule out poliovirus infection (WHO, 2004).

In the United States of America, the National Enterovirus Surveillance System (NESS) is a voluntary, passive surveillance system that has monitored trends in circulating EVs since 1961. Participating laboratories (state public health laboratories and local diagnostic laboratories willing to participate) report to CDC monthly summaries of enterovirus detections by virus type (i.e., serotype), with specimen type, collection date and demographic information. CDC summarizes the data and disseminates the results as shown in Table 1. Serotype-based EV surveillance provides a mechanism for determining patterns of enterovirus circulation and for identifying predominant serotypes for a given season. NPEVs are quite common, causing an estimated $10-15$ million or more symptomatic infections per year in the US alone (Pallansch et al., 2013).

Table 1. Reports of selected enteroviruses infections and isolation, by sex and age of source patient, specimen type and collection month, and outcome (Data from the National Enterovirus Surveillance System, United States, 1993-2005)

\begin{tabular}{|c|c|c|c|c|c|c|c|c|c|c|}
\hline \multirow[b]{2}{*}{$\begin{array}{c}\text { Selected } \\
\text { Serotypes }^{b}\end{array}$} & \multicolumn{4}{|c|}{ Specimen Collection Month } & \multicolumn{2}{|r|}{ Sex } & \multicolumn{2}{|c|}{ Age Groups (yrs) } & \multicolumn{2}{|c|}{ Specimen Type } \\
\hline & $\begin{array}{c}\text { June-Oct } \\
\%\end{array}$ & $\begin{array}{l}\text { Number } \\
\text { with } \\
\text { Known } \\
\text { Specimen } \\
\text { Collection } \\
\text { Month }\end{array}$ & $\begin{array}{r}\text { Out } \\
\text { \%Fatal }\end{array}$ & $\begin{array}{c}\text { Number } \\
\text { with } \\
\text { Known } \\
\text { Outcome }\end{array}$ & $\begin{array}{c}\% \\
- \text { Male } \\
\end{array}$ & $\begin{array}{c}\text { Number } \\
\text { with } \\
\text { Known } \\
\text { Sex }\end{array}$ & $\begin{array}{c}\% \\
<1 \text { to } 5 \text { to } \\
4 \quad 19\end{array}$ & $\begin{array}{l}\text { Number } \\
\text { with } \\
\text { Known } \\
\text { Age }\end{array}$ & 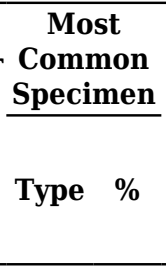 & $\begin{array}{l} \\
\text { No. with } \\
\text { Known } \\
\text { Specimen } \\
\text { Type }\end{array}$ \\
\hline Coxsackievirus A16 & 68.3 & 252 & 1.1 & 92 & 54.4 & 259 & 28.341 .316 .114 .3 & 223 & Other 41.2 & 199 \\
\hline Coxsackievirus A24 & 97.9 & 48 & $\mathrm{NA}^{\mathrm{c}}$ & 0 & 56 & 25 & 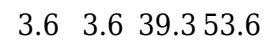 & 28 & Other 98 & 49 \\
\hline Coxsackievirus A9 & 80.9 & 1,176 & 1.7 & 346 & 56.8 & 1,257 & 39.416 .626 .517 .5 & 1,126 & $\operatorname{CSF}^{\mathrm{d}} 54.4$ & 1,048 \\
\hline Coxsackievirus B1 & 81.1 & 673 & 0 & 104 & 52.5 & 676 & 67.911 .210 .110 .8 & 651 & $\operatorname{Resp}^{\mathrm{e}} 39.9$ & 576 \\
\hline Coxsackievirus B2 & 79.1 & 1,188 & 3.8 & 263 & 59.1 & 1,293 & 63.414 .211 .411 & 1,157 & CSF 39.2 & 1,089 \\
\hline Coxsackievirus B3 & 78.3 & 787 & 5.4 & 130 & 56.6 & 830 & 63.714 .912 .39 .1 & 766 & Resp 38.6 & 664 \\
\hline Coxsackievirus B4 & 81.7 & 861 & 9.8 & 123 & 56.2 & 937 & $62.515 .5 \quad 9.6 \quad 12.4$ & 865 & CSF 41.1 & 755 \\
\hline Coxsackievirus B5 & 83.4 & 1,790 & 1.5 & 325 & 55.3 & 2,041 & 49.214 .916 .819 .1 & 1,844 & CSF 47.1 & 1,634 \\
\hline Echovirus 11 & 75.1 & 2,437 & 4.6 & 435 & 57.8 & 2,541 & 54.815 .613 .216 .3 & 2,327 & CSF 42.4 & 2,136 \\
\hline Echovirus 13 & 62.4 & 93 & NA & 1 & 59.2 & 397 & $\begin{array}{lll}44.9 & 11 & 31.512 .6\end{array}$ & 390 & CSF 54.1 & 392 \\
\hline Echovirus 18 & 79.7 & 661 & 1.8 & 57 & 57.2 & 934 & 41.412 .627 .618 .3 & 927 & CSF 54 & 752 \\
\hline Echovirus 3 & 79.7 & 182 & NA & 15 & 61.5 & 174 & 54.723 .613 .78 .1 & 161 & Resp 38.8 & 129 \\
\hline Echovirus 30 & 78.6 & 3,287 & 3.2 & 310 & 56.3 & 3,265 & 22.310 .942 .624 .2 & 3,068 & CSF 73.8 & 3,010 \\
\hline Echovirus 4 & 80 & 636 & 2.8 & 72 & 54.9 & 687 & 27.612 .936 .123 .4 & 595 & CSF 65 & 535 \\
\hline Echovirus 5 & 74.6 & 453 & 3.8 & 80 & 57.8 & 457 & 46.410 .922 .620 .1 & 412 & CSF 44.9 & 352 \\
\hline Echovirus 6 & 80.5 & 1,379 & 5.9 & 185 & 57.1 & 1,520 & 41.914 .624 .918 .5 & 1,414 & $\mathrm{CSF}$ & 1,284 \\
\hline Echovirus 7 & 76.5 & 1,214 & 2.5 & 203 & 57.2 & 1,139 & $\begin{array}{llll}57 & 17 & 14.1 & 11.9\end{array}$ & 1,055 & CSF 44.2 & 952 \\
\hline
\end{tabular}




\begin{tabular}{|c|c|c|c|c|c|c|c|c|c|c|c|c|c|}
\hline Echovirus 9 & 75.5 & 2,810 & 0.2 & 405 & 57.9 & 2,937 & 29.913 .53 & 6.9 & 19.7 & 2,653 & $\mathrm{CSF}$ & 67.5 & 2,627 \\
\hline Enterovirus 68 & 50 & 24 & NA & 1 & 59.1 & 22 & 29.435 .31 & 1.8 & 23.5 & 17 & Resp & 95.7 & 23 \\
\hline Enterovirus 71 & 70.5 & 237 & NA & 15 & 58.7 & 223 & 42.130 .71 & 1.9 & 15.3 & 202 & Resp & 40.2 & 174 \\
\hline $\begin{array}{l}\text { Human Parechovirus } \\
1\end{array}$ & 62.9 & 474 & 10.9 & 92 & 58.6 & 495 & 7322.6 & 2 & 2.4 & 456 & Resp & 45.2 & 321 \\
\hline $\begin{array}{l}\text { Human Parechovirus } \\
2\end{array}$ & 54.5 & 33 & NA & 8 & 55.9 & 34 & 67.620 .6 & 0 & 11.8 & 34 & Resp & 50 & 18 \\
\hline
\end{tabular}

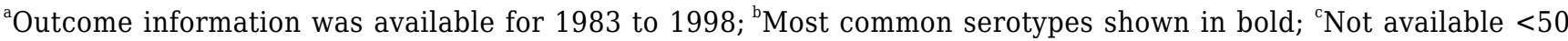
observations or outcome information not available; ${ }^{\mathrm{d} C S F}$ : cerebrospinal fluid; Resp: respiratory specimens; ${ }^{\mathrm{e}}$ Resp: respiratory specimens.

Adapted from (Khetsuriani et al., 2006)

The WHO maintains an integrated global alert and response system for epidemics and other public health emergencies based on strong national public health systems and capacity and an effective international system for coordinated response (www.who.int). Although enterovirus-associated fatalities involving poliomyelitis have been more consistently investigated, WHO continues to track the evolving infectious disease situation for other enterovirus diseases including acute flaccid paralysis or "poliomyelitis-like" infections associated with NPEVs. Among these newer enterovirus infections are those associated with enterovirus-71 (EV-71) and enterovirus D68 (EV-D68). EV-71 infection induces mild symptoms (e.g., hand-foot-mouth disease [HFMD] herpangina, or fever) in young children that can also lead to severe neurological and systemic complications, including meningitis, encephalitis, and central nervous system (CNS) involvement with cardiopulmonary failure. EV-71 is emerging as the most important virulent neurotropic EV during the poliomyelitis eradication period and countries of the Asian Pacific Rim in particular have been affected by large outbreaks of EV-71-associated HFMD with severe neurologic complications or systemic disease as described in Tables 2 and 3 (Cardosa et al., 2003; Huang et al., 2014; Pallansch et al., 2013; Ryu et al., 2010). The transmission of EV-71 infections in other geographical areas is poorly understood.

Table 2. Demographic factors and clinical outcomes of Enterovirus (EV)71 - infected patients (from metropolitan areas of Taipei, Taichun, and Kaohsiun in Taiwan between May 2011 and November 2012)

\begin{tabular}{|c|c|c|c|c|c|}
\hline \multirow{2}{*}{ Demography/Outcome } & \multicolumn{5}{|c|}{ EV 71 Severity } \\
\hline & $\begin{array}{l}\text { Uncomplicated } \\
(n=153) \\
\end{array}$ & $\begin{array}{l}\text { Meningitis/Myoclonic } \\
\text { Jerk }(n=193)\end{array}$ & $\begin{array}{l}\text { Encephalitis } \\
(\mathbf{n}=35) \\
\end{array}$ & $\begin{array}{c}\text { CNS }^{b} \text { Involvement } \\
\text { with PE }(n=18)\end{array}$ & $\mathbf{p}^{\mathbf{c}}$ \\
\hline Mean age $\pm \mathrm{SD}^{\mathrm{d}}$ (years) & $3.29 \pm 2.64$ & $3.32 \pm 2.62$ & $2.23 \pm 3.87$ & $2.49 \pm 0.77$ & 0.25 \\
\hline \multicolumn{6}{|l|}{ Sex } \\
\hline Male & $93(60 \%)$ & $114(59 \%)$ & $21(60 \%)$ & $12(67 \%)$ & 0.94 \\
\hline Female & $61(40 \%)$ & $79(41 \%)$ & $14(40 \%)$ & $6(33 \%)$ & \\
\hline \multicolumn{6}{|l|}{ Age } \\
\hline$>2 \mathrm{y}$ & 107 (70\%) & 107 (55\%) & $21(60 \%)$ & $10(56 \%)$ & 0.05 \\
\hline$\leq 2 \mathrm{y}$ & $46(30 \%)$ & $86(45 \%)$ & $14(40 \%)$ & $8(44 \%)$ & \\
\hline \multicolumn{6}{|l|}{ Prerequisite illness } \\
\hline Preterm birth & $8(5 \%)$ & $19(10 \%)$ & $4(11 \%)$ & $2(11 \%)$ & 0.37 \\
\hline Developmental delay & $3(2 \%)$ & $6(3 \%)$ & $0(0 \%)$ & $3(17 \%)$ & 0.004 \\
\hline $\begin{array}{l}\text { Previous admission due } \\
\text { to EV }\end{array}$ & $15(10 \%)$ & $29(15 \%)$ & $2(6 \%)$ & $0(0 \%)$ & 0.10 \\
\hline \multicolumn{6}{|l|}{$\begin{array}{l}\text { Interval between onset } \\
\text { and hospital visit }\end{array}$} \\
\hline 0 to 2 days & $69(45 \%)$ & $102(53 \%)$ & $4(11 \%)$ & $1(6 \%)$ & $<0.001$ \\
\hline 3 to 8 days & $84(55 \%)$ & $91(47 \%)$ & $31(89 \%)$ & $17(94 \%)$ & \\
\hline \multicolumn{6}{|l|}{ Clinical outcome } \\
\hline Full recovery & $53(100 \%)$ & $193(100 \%)$ & $34(97 \%)$ & $12(67 \%)$ & $<0.001$ \\
\hline Morbidity & $0(0 \%)$ & $0(0 \%)$ & $1(3 \%)$ & $4(22 \%)$ & \\
\hline Fatality & $0(0 \%)$ & $0(0 \%)$ & $0(0 \%)$ & $2(11 \%)$ & \\
\hline
\end{tabular}


${ }^{a}$ EV: Enterovirus; ${ }^{b} \mathrm{CNS}$ : Central nervous system; ${ }^{\mathrm{c}} p$ value denoting statistical significance from the analysis of the clinical outcomes of all participants and the associations among disease severity and the possible predisposing factor; ${ }^{\mathrm{d}} \mathrm{SD}$ : Standard deviation.

Adapted from: (Huang et al., 2014)

Table 3. Summary of Enterovirus 71 outbreaks in Asia (1998 - 2009)

\begin{tabular}{|c|c|c|c|c|c|}
\hline \multirow[b]{2}{*}{ Outbreak Location, Year } & \multicolumn{2}{|c|}{ HFMD $^{\mathbf{a}}$} & \multicolumn{3}{|c|}{ Complicated HFMD $^{\mathrm{a}}$} \\
\hline & $\begin{array}{l}\text { Number of } \\
\text { Patients }\end{array}$ & $\begin{array}{c}\text { Number of } \\
\text { Patients with } \\
\text { EV71 }\end{array}$ & $\begin{array}{l}\text { Number of } \\
\text { Patients }\end{array}$ & $\begin{array}{c}\text { Number of } \\
\text { Patients with } \\
\text { EV71 } \\
\end{array}$ & Genotypes Detected \\
\hline $\begin{array}{l}\text { Brunei, Southeast Asia, } \\
2006\end{array}$ & $\geq 100$ & 34 & $\mathrm{NR}^{\mathrm{b}}$ & NR & B4, B5 \\
\hline Fuyang, PRC 2008 & 151 & 59 & 112 & 42 & $\mathrm{C} 4 \mathrm{a}$ \\
\hline Shandong, PRC, 2007 & 105 & 55 & 11 & 6 & $\mathrm{C} 4 \mathrm{a}$ \\
\hline $\begin{array}{l}\text { Sarawak, Malaysia, } 2000 \\
\text { to } 2004\end{array}$ & 773 & 277 & 102 & 56 & B4, C1, B5 \\
\hline South Korea, 2009 & 519 & 168 & 112 & 92 & C4a, C1, C5 \\
\hline Taiwan, 1998 & NR & NR & 405 & 78 & $\mathrm{C} 2$ \\
\hline
\end{tabular}

${ }^{a}$ HFMD: Hand-foot-and-mouth-disease; ${ }^{b}$ NR: Not reported; ${ }^{c}$ PRC: People's Republic of China.

Countries of the Asia Pacific Rim affected by large outbreaks of EV71-associated hand-foot-and-mouth disease (HFMD). Best documented outbreaks with prevalence of neurologic complications of EV71 infection among outbreaks assumed to have been driven by differences of genotypes and co-infection with other viruses, such as a newly characterized adenovirus.

Adapted from (Ryu et al., 2010)

EV-D68 infection has been associated with acute respiratory illness of differing severities ranging from mild upper respiratory tract infections to severe pneumonia including fatal cases in pediatric and adult patients (Imamura and Oshitani, 2015; Oberste et al., 2004). EV-D68 has been recognized as a reemerging pathogen due to its high frequency of detection in different parts of the world since 2008 - 2009 (Table 4). In the United States, the National Enterovirus Surveillance System received 79 EVD68 reports during 2009 - 2013 (Midgley et al., 2014).
Cases of respiratory syndrome with neurological complications, including acute flaccid myelitis, have been reported in the USA, Canada, Norway, and France (Khan, 2015; Lang et al., 2014; Milhano et al., 2015). However recent investigations indicate that EV-D68 infection is most commonly associated with respiratory illness and no definitive connection between EV-D68 and acute flaccid myelitis has been established (http://www.cdc.gov/ncird/investigation/viral/2014-15/invest igation.html).

Table 4. Human enterovirus D68 cases, by cluster location and age group in Asia, Europe, and United States (2008 - 2010)

\begin{tabular}{|c|c|c|c|c|c|}
\hline \multirow[t]{2}{*}{ Area } & \multirow[t]{2}{*}{ Number of Cases Overall } & \multicolumn{4}{|c|}{ Age Groups (Years) } \\
\hline & & 0 to 4 & 5 to 9 & 10 to 19 & $\geq 20$ \\
\hline Japan & 11 & 10 & 1 & 0 & $\overline{\mathrm{NR}^{\mathrm{a}}}$ \\
\hline Netherlands & 24 & 11 & 1 & 0 & 12 \\
\hline Philippines & 21 & 17 & 2 & 2 & NR \\
\hline USA (Arizona) & 5 & 1 & 2 & 2 & NR \\
\hline USA (Georgia) & 6 & 0 & 0 & 0 & 6 \\
\hline USA (Pennsylvania) & 28 & 15 & 5 & 8 & NR \\
\hline Total & 95 & 54 & 11 & 12 & 18 \\
\hline
\end{tabular}




\section{${ }^{\mathrm{a} N R}$ : Not reported}

Young children were found to be most at risk ( 0 to 4 years of age)

Adapted from Clusters of Acute Respiratory Illness Associated with Human Enterovirus 68 - Asia, Europe, and United States, 2008 - 2010. (Annon, 2011) http://idsc.nih.go.jp/iasr/virus/virus-e.html

In temperate regions of the world, the majority of EV infections (70 to 80\%) occur in summer and fall, whereas in the tropics, EV infections occur year-round or with increased incidence during the rainy season. Unexplained cycles of infection (i.e., 2, 3, 4 or 5 years) of some human EVs have been identified (Pallansch et al., 2013; Stellrecht et al., 2010).

\subsubsection{Symptomology}

Table 5 shows Picornavirus genera and enterovirus species associated with disease in humans. While most enterovirus infections are asymptomatic and mild febrile illness (e.g., respiratory illness and febrile rash illness) has been recognized as the most common symptomatic manifestation of infection, EVs are also associated with severe neurological illness, such as aseptic meningitis and encephalitis. Aseptic meningitis seems to be the most common severe clinical manifestation associated with enterovirus infection in children and adults, especially in developed countries (Pallansch et al., 2013; Stellrecht et al., 2010; Tapparel et al., 2013). PVs are perhaps the most studied and characterized of the EVs, especially given the clinical consequences of infection which can infect motor neurons of the anterior horn of the spinal cord and lead to paralytic poliomyelitis in humans (Rhoades et al., 2011). Infants infected with Coxsackievirus (CV) have been shown to be extremely susceptible to myocarditis, meningitis and encephalitis with a subsequent mortality rate as high as 10\% (Rhoades et al., 2011). EV-71 is a major public health issue across Asia and of increasing concern globally, causing HFMD with potential neurological complications as previously discussed (Rhoades et al., 2011). Echoviruses are highly infectious and preferentially target infants and young children. These viruses can cause a mild, nonspecific illness similar to that of CVs. Other clinical syndromes associated with NPEV infections include acute hemorrhagic conjunctivitis caused by multiple EV serotypes such as coxsackievirus type A24 variant (CVA24), enterovirus type 70 (EV-70), and E-71; coxsackieviral myocarditis (i.e., inflammation of the myocardium) caused by coxsackievirus group B (CVB); enteroviral respiratory infections caused by Coxsackievirus group A (CVA) and CVB serotypes as well as echovirus types $6,9,11,16,17,22$, and 25; acute gastroenteritis caused by echovirus types 1, 7, 11, 13, 14, 30 and 33. Consequently, no enteroviral disease is uniquely associated with any specific serotype, and no serotype is uniquely associated with any one disease (Pallansch et al., 2013; Tapparel et al., 2013).

Table 5. Picornavirus genera and enterovirus species associated with diseases in humans (Over 111 enterovirus genotypes discovered and most reported in sewage)

\begin{tabular}{|c|c|c|c|c|}
\hline Genus & Species & Genotypes & Associated Disease & Strains \\
\hline \multirow{10}{*}{ Enterovirus } & \multirow{10}{*}{$\begin{array}{c}\text { Human } \\
\text { enterovirus A } \\
\text { (EV-A) }\end{array}$} & \multirow{10}{*}{$\begin{array}{c}\text { Coxsackievirus } \\
\text { (CV) Enterovirus } \\
(\mathrm{EV})\end{array}$} & Encephalitis & $\begin{array}{l}\text { CV-A2, CV-A3, CV-A4, CV-A5, CV-A6, } \\
\text { CV-A7, CV-A8, CV-A16, EV-A71 }\end{array}$ \\
\hline & & & Paralysis or myelitis & $\begin{array}{l}\text { CV-A2, CV-A4, CV-A5, CV-A7, CV-A8, CV-A16, } \\
\text { EV-A71, EV-A76, EV-A89, EV-A90, EV-A91 }\end{array}$ \\
\hline & & & Meningitis & $\begin{array}{c}\text { CV-A2, CV-A3, CV-A4, CV-A5, CV-A6, CV-A7, } \\
\text { CV-A8, CV-A10, CV-A16, EV-A71 }\end{array}$ \\
\hline & & & Hand-foot-and-mouth disease & $\begin{array}{c}\text { CV-A4, CV-A5, CV-A6, CV-A7, CV-A10, CV- } \\
\text { A12, CV-A16, EV-A71 }\end{array}$ \\
\hline & & & Upper and lower respiratory disease & CV-A10, CV-A16, EV-A71 \\
\hline & & & Pleurodynia & CV-A2, CV-A4, CV-A6, CV-A10, CV-A16 \\
\hline & & & Herpangina & $\begin{array}{c}\text { CV-A2, CV-A3, CV-A4, CV-A5, CV-A6, CV-A7, } \\
\text { CV-A8, CV-A10, CV-A16, EV-A71 }\end{array}$ \\
\hline & & & Gastroenteritis & EV-A76, EV-A71, EV-A89, EV-A90 \\
\hline & & & Myopericarditis & CV-A16, EV-A71 \\
\hline & & & $\begin{array}{l}\text { Pancreatitis } \\
\text { Type I diabetes }\end{array}$ & $\begin{array}{l}\text { EV-A71 } \\
\text { EV-A71 }\end{array}$ \\
\hline
\end{tabular}

Encephalitis

Paralysis or myelitis
CV-A9, CV-B1, CV-B2, CV-B3, CV-B4, CV-B5, E-3, E-4, E-5, E-6, E-7, E-9, E-11, E-13, E-14, E-16, E-17, E-18, E-19, E-24 E- 25, E-27, E-30, E-33

CV-A9, CV-B1, CV-B2, CV-B3, CV-B4, CV-B5, CV-B6, E-1, E-2, E-3, E-4, E-5, E-6, E-7, E-9, E-11, E-12, E-13, E-14, E-16, E-18, E-20, E-21, E-25, E-27, E-29, E-30, E-33, EV-B75, EV-B77, EV-B81,

EV-B85, EV-B86, EV-B87, EV-B88, EV-B93, EV- B97, EV-B100 


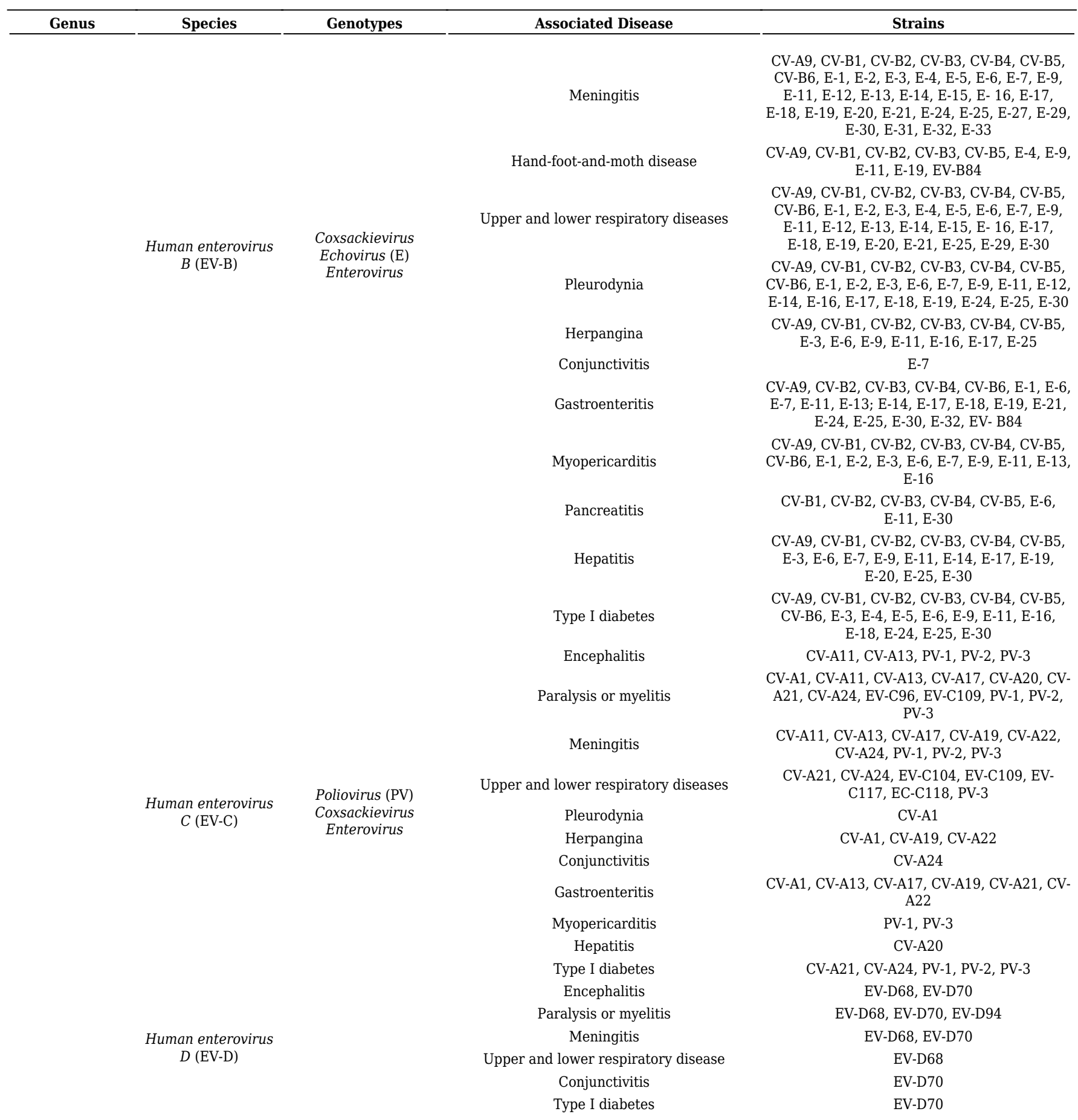

Cardiovirus

(Saffold virus,

SAFV)

Hepatovirus

Kobuvirus

Parechovirus

Cosavirus

Salivirus
Cardiovirus

Hepatovirus A

Aichi virus

Parechovirus A Parechovirus $B$

Cosavirus $A$

Salivirus A
Cardiovirus A Cardiovirus $B$ Cardiovirus $C$

Hepatitis A virus

Aichi virus A

Aichi virus $B$ Aichi virus $C$

$16 \mathrm{HPeV}$ types

Cosavirus $A$ Salivirus A
Potential association with gastrointestinal and respiratory tract infections, and neurological disorders

Enteric hepatitis

Gastroenteritis

Potential association with gastrointestinal, respiratory and central nervous system (CNS)related manifestations (i.e, encephalitis)

Potential association with non-polio acute flaccid paralysis and acute diarrhea Potential association with gastroenteritis

Modified from Pallansch et al.(Pallansch et al., 2013) and Tapparel et al. (Tapparel et al., 2013), with the classification of Cardiovirus, Salivirus, Kobuvirus based on Virus Taxonomy: 2014 Release (International Committee on Taxonomy of Viruses) http://www.ictvonline.org/taxonomyReleases.asp Last accessed Feb. 2016. 


\subsection{Taxonomic Classification}

\subsubsection{Physical description of the agent}

EVs, like other members of the family Picornaviridae, are non-enveloped icosahedral particles (i.e., virions) $\sim 30$ $\mathrm{nm}$ in diameter. Virions consist of a protein shell (capsid) surrounding the naked single-stranded positive (message)sense RNA genome (Racaniello, 2013; Stellrecht et al., 2010). EVs are distinguished from other picornaviruses on the basis of physical properties, including buoyant density in cesium chloride and acid stability (Pallansch et al., 2013). EVs and cardioviruses have a buoyant density of $1.34 \mathrm{~g} / \mathrm{mL}$, while parechoviruses (HPeVs) and rhinoviruses (HRVs) have an intermediate value of $1.36 \mathrm{~g} / \mathrm{mL}$ and 1.40 $\mathrm{g} / \mathrm{mL}$, respectively and such differences lie in the permeability of the viral capsid to cesium (Racaniello, 2013). EVs (except HRVs), hepatoviruses, and HPeVs are acid stable and retain infectivity at $\mathrm{pH}$ values of 3.0 and lower. In contrast, HRVs are labile at $\mathrm{pH}$ values of less than 6.0. Differences in $\mathrm{pH}$ stability influence the sites of replication of the virus, for instance, HRVs replicate in the respiratory tract and need not be acid stable while cardioviruses, EVs, hepatoviruses, and $\mathrm{HPeVs}$ pass through the stomach to gain access to the intestine and, therefore, must be resistant to low pH (Racaniello, 2013).

EVs are relatively resistant to many common laboratory disinfectants, including 70\% ethanol, isopropanol, dilute Lysol, and quaternary ammonium compounds. The virus is insensitive to lipid solvents, including ether and chloroform, and it is stable in many nonionic detergents at ambient temperature. Formaldehyde, glutaraldehyde, strong acid, sodium hypochlorite, and free residual chlorine inactivate EVs (Pallansch et al., 2013; Stellrecht et al., 2010)). Chlorine disinfection is a critical step for inactivation of viruses in water and wastewater treatment processes Ideal conditions for virus inactivation are high chlorine residual, long contact time, high water temperature, low $\mathrm{pH}$, low turbidity, and an absence of interfering substances (DEP, 2011)(see Section III).

In the environment, EV virions are relatively thermostable, but less so than hepatitis A virus that is distinguished from other picornaviruses by its high thermal stability (Anderson and Counihan, 2011; Pallansch et al., 2013). EVs, like other picornaviruses, have evolved thermal stability (stable at $42^{\circ} \mathrm{C}$ or up to $50^{\circ} \mathrm{C}$ in the presence of sulfhydryl reducing agents and magnesium cations) and $\mathrm{pH}$ stability (pH 3-9) in the extracellular environment, which is the result of the assembly of virus particles of all picornaviruses (Gerba et al., 2007; Hurst and Adcock, 2000; Hurst and Murphy, 1996; National Research Council, 2004; Racaniello, 2013). Indeed, the biophysical properties of picornaviruses such as their small-size (30 nm), genome type (ssRNA), and non-enveloped protein capsid structure of the virion are known to play an important role on the mechanisms of virus survival and transport in the environment (Bosch et al., 2006; Fong and Lipp, 2005;
Gerba et al., 2013; National Research Council, 2004; Sobsey and Meschke, 2003; Wigginton and Kohn, 2012; Xagoraraki et al., 2014). In particular, the electrostatic and hydrophobic interactions involving functional groups of the viral capsid (i.e., charged amino acids residues) are essential for capsid assembly, capsid stability, and virus particle adsorption to solid surfaces (e.g., suspended solids, sediments and environmental surfaces or fomites) (Mateu, 2011; Michen and Graule, 2010). Studies have suggested that picornaviral capsids are also stabilized by interactions with the RNA genome (Pallansch et al., 2013). Additional studies conducted with PV strains (serotype 1 virulent Mahoney and serotype 1 attenuated Sabin) have indicated that viral binding to bacteria or bacterial polysaccharides offers a selective advantage by enhancing environmental stability of the virions (Robinson et al., 2014).

The capsids of EVs and other picornaviruses are composed of four viral structural proteins (i.e., VP1, VP2, VP3, and VP4) arranged in 60 repeating protomeric units (protomers) that confer an icosahedral shape to the virion. The shell is formed by VP1 to VP3, and VP4 lies on its inner surface. VP1, VP2, and VP3 comprise the surface of the virion with a similar topology forming an eight-stranded, antiparallel $\beta$-barrel core structure. Packing of the $\beta$-barrel domains is strengthened by a network of protein-protein contacts on the interior of the capsid, particularly around the fivefold axes of symmetry. This network, which is formed by the N-terminal extensions of VP1 to VP3 and VP4, is essential for the stability of the virion (Racaniello, 2013). Similarly, a network formed by the N-termini on the interior of the capsid contributes significantly to the stability of the virions. Furthermore, studies have suggested that picornaviral capsids are stabilized by interactions with the ssRNA genome. The positive strand ssRNA genome of EVs and all picornaviruses serves as a template for both viral protein translation and RNA replication. In fact, the viral ssRNA is infectious because it is translated on entry into the cell to produce all the viral proteins required for viral replication (Pallansch et al., 2013; Stellrecht et al., 2010).

\subsubsection{Taxonomy and diversity in the Picornaviridae}

Enterovirus corresponds to the genus within the Picornaviridae family. This family belongs to the order Picornavirales and comprises 12 genera, which all contain viruses that infect vertebrates (i.e., Apthovirus, Avihepatovirus, Cardiovirus, Enterovirus, Erbovirus, Hepatovirus, Kobuvirus, Parechovirus, Sapelovirus, Senecavirus, Tremovirus, Teschovirus) (Racaniello, 2013). Picornavirus genera and enterovirus serotypes infecting humans are presented in Table 5.

Members of the Echovirus genus originally known as echovirus 22 and 23 have been reclassified within the genus Parechovirus based on distinctive biological and molecular properties. To date, 16 genotypes of human parechoviruses (HPeVs) have been identified (Harvala and 
Simmonds, 2009). Likewise, the former Rhinovirus genus has been reclassified within the Enterovirus genus based on its genome organization and particle structure (Tapparel et al., 2013).

With respect to EVs, the current taxonomic classification scheme (Virus Taxonomy: 2014 Release (International Committee on Taxonomy of Viruses) http://www.ictvonline.org/taxonomyReleases.asp last accessed Feb. 2016) based on genome organization and biological properties of viruses plus high-throughput EV genome sequencing and bioinformatics analysis, divides human EVs into four species: Enterovirus A, B, C, and D. The classification scheme keeps traditional names for individual serotypes (i.e., coxsackievirus, echovirus, enterovirus, poliovirus). The following species designation criteria based on molecular and biological features have been established: HEV species share amino acid percent identities from $60 \%$ to greater than $70 \%$ within specific genomic coding regions, share a limited range of host cell receptors and a limited natural host range; have a $\mathrm{G}+\mathrm{C}$ genome base composition which varies by no more than $2.5 \%$; and share a significant degree of compatibility in proteolytic processing, replication, encapsidation, and genetic recombination.

Approximately 107 serotypes/genotypes of NPEVs have been identified based on a threshold of $25 \%$ nucleotide divergence in the VP1 coding region (Pallansch et al., 2013). The serotype of an unknown isolate is inferred by comparison of the VP1 sequence with a database containing VP1 sequences for the prototype and variant strains of all human EV serotypes according to the following suggested guidelines:

i. A partial or complete VP1 nucleotide sequence identity of $75 \%$ (>85\% amino acid) identity between a clinical EV isolate and serotype prototype strain is used to establish the serotype of the isolate, on the provision that the second highest score is $<70 \%$

ii. A best-match nucleotide sequence identity of $<70 \%$ may indicate that the isolate represents an unknown serotype,

iii. A sequence identity between $70 \%$ and $75 \%$ indicates that further characterization is required before the isolate can be firmly identified.

VP1 nucleotide sequence comparison can be used to rapidly determine whether viruses isolated during an outbreak are epidemiologically related (Manor et al., 2007; Pallansch et al., 2013; Shulman et al., 2012; Shulman et al., 2015).

New genera of the Picornaviridae family (i.e., Cardiovirus also referred to as Saffold cardiovirus or SAFV, Cosavirus, a common stool-associated picornavirus, and Salivirus, a stool Aichi-like virus) have been identified in fecal specimens and in sewage using conventional and highly-sensitive genome sequencing technologies (Greninger et al., 2009; Jones et al., 2007; Kapoor et al., 2008; Tapparel et al., 2013). Although these viruses have been associated with disease in humans, they do not appear to be a major cause of human illness; therefore, their clinical significance remains to be fully elucidated.

It is known that EV activity in populations can be either sporadic or epidemic, and that certain EV types may be associated with both sporadic and epidemic disease occurrences. The patterns of virus shedding and routes of transmission for EVs are consistent with few exceptions. The largest amount and duration of virus shedding occurs upon primary infection with a given serotype and most primary infections occur during childhood. Consequently, young children are possibly the most important transmitters of EV within households (Pallansch et al., 2013).

\subsection{Transmission}

\subsubsection{Routes of transmission}

Transmission of human EVs to susceptible individuals occurs via fecal - oral, oral - oral and nasopharyngeal routes (respiratory droplets), and via fomites. Most EVs enter primarily by the fecal - oral route and replicate in the gastrointestinal tract, including the oropharyngeal and intestinal mucosa. Following replication, EVs may cause both localized and systemic infections, affecting many organ systems in patients of all ages. Some EVs have a restricted respiratory tropism (e.g. HRVs) while others can invade the CNS and induce neurological disease (Pallansch et al., 2013; Rhoades et al., 2011; Tapparel et al., 2013). It is well documented that the fecal - oral pathway of EV transmission predominates in areas with poor sanitary conditions, while respiratory transmission predominates in more developed areas. Consequently, the relative importance of the different modes of transmission probably varies with the particular EV and environmental settings. HRVs are traditionally associated with upper respiratory tract infection, otitis media, and sinusitis, and therefore are predominantly transmitted from person to person via direct contact or through a fomite or small or large particle aerosol (Jacobs et al., 2013).

Evidence of more specific modes of enterovirus transmission by the fecal - oral route via environmental contamination (e.g., contaminated food [shellfish] and water sources) are described in detail in specific sections of this chapter. Since EVs are enteric viruses, water-related transmission remains of primary importance for indirect human enterovirus transmission.

\subsubsection{Reservoirs and fecal shedding}

Contaminated water and some food sources may serve as reservoirs of the environmentally-stable EV virions, but humans are thought to make up the only important natural reservoir for replication of human EVs (Gerba et al., 2013; Pallansch et al., 2013). Most EVs, excluding Enterovirus 70 (EV70) coxsackievirus A24 (CVA24) are abundant in stool specimens of infected individuals and levels of excretion of PVs are known to reach maximal amounts of $10^{6}$ infectious virons per gram of feces (Dowdle et al., 2002; Hovi et al., 2007). Less information is available for levels of excretion of other enterovirus genotypes; however, the consensus from previous and current references indicates that 
humans excrete between $10^{6}$ and $10^{7}$ EVs per gram of feces (Feachem et al., 1983b; Gerba, 2000; Melnick and Rennick, 1980). The duration of intestinal virus shedding and thus the spreading (i.e., transmission) of a particular enterovirus may vary among the different genotypes. For example, longer periods of excretion have been documented for PVs and CVs (Pallansch et al., 2013). Additional studies have indicated that EV excretion may persist for up to 11 weeks after an EV infection (Chung et al., 2001). Furthermore, long-term PV excretion ranging from 10 months to 28 years has been documented for individuals with immunodeficiencies (Dunn et al., 2015; Kew et al., 1995).

\subsection{Population and Individual Control Measures}

\subsubsection{Poliomyelitis vaccination and eradication update}

Following the eradication of smallpox, paralytic poliomyelitis (i.e., AFP) caused by wild polioviruses (WPV, serotypes 1, 2 and 3) became a major focus of public health activity. Most childhood EV and PV infections are asymptomatic. Surprisingly, on average only about 1 in 200 to 1000 poliovirus infections in fully susceptible individuals results in paralytic disease and drops to 1 in a few millions for vaccinated individuals. The most common symptomatic disease caused by PVs is a mild febrile illness with or without gastrointestinal signs (i.e., abortive poliomyelitis) that occurs in $4 \%$ to $8 \%$ of individuals. Less frequently infection may lead to non-paralytic illness characterized by the typical features of viral meningitis. (Pallansch et al., 2013). Person-to-person WPV transmission can occur in the absence of the relatively rare symptomatic infections especially in highly vaccinated populations (Shulman et al., 2014).

In 1988 the World Health Assembly adopted the Global Polio Eradication Initiative (GPEI) to eradicate all three serotypes of poliovirus. This effort has involved both health professionals and more than ten million volunteers in all countries (WHO, 2014). Success of any eradication program depends on an effective intervention strategy and sensitive and easily performed surveillance systems able to detect the pathogen. For polio, intervention was based on the availability of an oral polio vaccine (OPV) consisting of live attenuated poliovirus strains and an inactivated polio vaccine (IPV) containing inactivated neurovirulent vaccine strains. Each vaccine type has advantage and disadvantages (see reviews by (Plotkin and Vidor, 2008; Shulman, 2012; Sutter et al., 2008). Both OPV and IPV were trivalent to raise antibodies against the three noncross-reacting poliovirus serotypes. The gold standard for PV surveillance is based on investigation of the cause of all cases of AFP in children $\leq 15$ years of old to determine whether or not the AFP was caused by poliovirus (Pallansch et al., 2013). Poliovirus is considered to be absent when the number of AFP cases investigated is 1 per 100,000 children $\leq 15$ of age (the rate for all non-PV causes of AFP) and none were due to PV. A supplementary or alternative approach is to conduct environmental surveillance (ENVS) of sewage and other wastewaters, to test whether PVs are present in samples collected from these sources. The advantage of ENVS is that it can detect PV circulation in the absence of clinical cases since virus is excreted into sewage during asymptomatic infections as well as symptomatic infections. Moreover, results can be semi quantitative as well as qualitative (Hovi et al., 2012; Hovi et al., 2001; Lodder et al., 2012; Manor et al., 2014).

A review of publications between 1935 and 1995 on excretion of polioviruses by Alexander and associates (Alexander et al., 1997) indicated that in most infections of nalve children, wild polioviruses were excreted for $3-4$ weeks with a mean rate of $45 \%$ at 28 days, and $25 \%$ of the cases were still excreting during the sixth week. In contrast, fewer than $20 \%$ excreted vaccine strains after 5 weeks. Excretion of polio ranged from a few days to several months (Minor, 1992). The highest probability of detecting poliovirus positive stool samples was reported to be at 14 days after the onset of paralysis (Alexander et al., 1997; Dowdle and Birmingham, 1997) and is the basis of stool sample collection for diagnosis of polio by AFP surveillance (WHO, 2004). The Global Polio Laboratory Network of laboratories accredited by the WHO provides the surveillance arm necessary for successful eradication. Standard laboratory procedures were adopted for AFP) surveillance (WHO, 2004).

The GPEI has made significant advances towards eradication of poliomyelitis. To date, nearly $80 \%$ of the world's population lives in areas certified as polio-free. The last reported infection with WPV2 was reported in 1999 (MMWR, 2001) and type two WPV was declared eradicated by the WHO on September 20, 2015 http://www.polioeradication.org/mediaroom/newsstories/Gl o ba l-eradic a ti on - of - wild - p olioviru s-type - 2 declared/tabid/526/news/1289/Default.aspx. This declaration prepared the way for the global withdrawal of type 2 PV from trivalent OPV by April 2016, and the subsequent destruction of all materials that contain type 2 OPV by July 2016 (WHO, 2015b) in all but a few specially designated laboratories. No circulating WPV3 has been reported since November 2012 (Kew et al., 2014). Countries where transmission of wild poliovirus has not yet been interrupted for greater than three years are Afghanistan and Pakistan. Significantly, no polio cases have been reported for more than one year in Nigeria. The international spread of WPV1 was declared a public health emergency of international concern (PHEIC) in May 2014 during the $4^{\text {th }}$ IHR Emergency Committee meeting regarding the international spread of wild poliovirus http://www.who.int/mediacentre/news/statements/2015/poli o-27-february-2015/en/ since continued circulation of WPV1 in endemic countries risked reintroduction of PV1 into polio-free areas of the world, for example by travelers, refugees from Africa and the Middle East.

Evidence of global interruption of transmission of WPV has been based primarily on AFP surveillance. ENVS and AFP surveillance will be critically important during the end stage of eradication and post eradication for documenting eradication and ensuring very early detection of any reemergence. ENVS will be especially important for populations with high IPV vaccine coverage, since the ratio of AFP cases to asymptomatic infections would be orders of magnitude lower than for under-vaccinated populations (Hovi et al., 2012). (The latest information on global 
eradication can be viewed at http://www.polioeradication.org/). Improving methodologies and expanded use of environmental surveillance have become one of the goals of the WHO, the Rotary International and the Bill \& Melinda Gates Foundation.

Live attenuated polio vaccine can be transmitted from person-to-person, a trait considered advantageous when WPV infections were endemic, but which is now problematic as the eradication endgame approaches (Dowdle et al., 2003). Specifically, like wild poliovirus, the OPV genome evolves during circulation. Some of the OPV progeny may revert to neurovirulence. AFP from reverted vaccine strains (e.g., vaccine associated paralytic poliomyelitis (VAPP)) occurs very rarely (1 per 500,000 to $1,000,000$ primary vaccinations of naive individuals) and in rarely, these neurovirulent vaccine-derived strains (VDPVs) have circulated and caused outbreaks of poliomyelitis in poorly vaccinated populations (Kew et al., 2005). As a consequence there is a major effort to develop new, improved, and safer live polio vaccine stocks promoted by the WHO, Rotary and the Bill and Melinda Gates association. Three different approaches have been funded to reduce the risk for vaccine-derived poliovirus causing outbreaks of poliomyelitis and are in advanced stages of completion prior to clinical testing. These approaches include genetically engineering PV to de-optimize codon usage in the capsid region; increasing poliovirus polymerase fidelity and reducing recombination capacity; and relocating the cis-acting replication element (cre) to attenuate or minimize recombination. Alternative approaches include use of noninfectious DNA, immunogenic peptides and antiviral drugs. All will need more testing against PV.

Development of a general anti-EV vaccine appears to be very difficult due to significant EV genetic variability. However efforts have been initiated to develop a vaccine against specific EVs most notably EV-71 (Liang and Wang, 2014; Lu, 2014; Zhu et al., 2014).

\subsubsection{Hygiene measures}

Wastewater treatment (WWT) includes biological treatment (e.g., conventional activated sludge, waste stabilization ponds, trickling filters), physicochemical treatment (e.g., sedimentation, media or membrane filtration), conventional oxidation (e.g., chlorine and ozone), and advanced treatment technologies (e.g., membrane bioreactors, microfiltration, ultrafiltration, constructed wetlands, chemical coagulation, and disinfection with ultraviolet irradiation and ozone. WWT can also include steps that remove other hazardous contaminants of urban wastes, e.g., toxic chemicals, heavy metals, pharmaceuticals. A by-product of domestic wastewater or sewage treatment is sewage sludge, a semi-solid slushy mass, deposit, or sediment produced by sedimentation during water and sewage treatment processes. This sludge contains enteric pathogens and needs to be properly treated for recycling or disposal (discussed below in Section III). Multiple levels of wastewater treatment (preliminary, primary, secondary, and tertiary or advanced) and combination of their corresponding treatment technologies are required to consistently reduce, remove and/or inactivate the vast numbers of viruses present in all the wastes sent into the sewer from drains and toilets (Costan-Longares et al., 2008; Francy et al., 2012; Haramoto and Otagiri, 2013; Harwood et al., 2005; Hegazy et al., 2013; Katayama et al., 2008; Kitajima et al., 2014a; Kitajima et al., 2014b; Kitajima et al., 2015; La Rosa et al., 2010; Locas et al., 2010; $\mathrm{Ng}$ et al., 2012; Ottoson et al., 2006a; Rock et al., 2015; Simmons et al., 2011; Simmons and Xagoraraki, 2011a; Symonds et al., 2014). The greater the exposure of the public to these contaminated sources, the greater the need for treatment to reduce all viral pathogens and hazardous contaminants present in these wastes (Gerba et al., 2013; Rock et al., 2015; Xagoraraki et al., 2014).

Person-to-person EV transmission can also be interrupted by physical hygienic means. These include directly stripping EVs from the surfaces of foods, hands, and other surfaces by adequate washing, disinfecting materials and surfaces used for food production, heating the food to inactivate virus, and using uncontaminated or treated water. Unfortunately, facilities that hygienically separate human excreta from human contact are unavailable for approximately 2.4 billion people or one third of the current global population (Graham and Polizzotto, 2013; WHO and UNICEF, 2015).

\subsection{Environmental Occurrence and Persistence}

Numerous methods have been used to evaluate the occurrence and persistence of EVs and other human picornaviruses in environmental waters. 2.1 of this Section details the extensive research that has been accumulated over the past few years. The current state of knowledge about the occurrence and persistence of EVs and other human picornaviruses in different environmental sources is documented in 2.2 and 2.3 of this Section. See Reviews by Faechem et al. (Feachem et al., 1980; Feachem et al., 1983a) for a review of literature before 1983.

\subsection{Detection Methods}

The selection of an appropriate filtration method for the primary concentration of viruses is crucial for successful virus detection (Rajal et al., 2007). Interestingly, the efficiency of virus recovery by these methods depends largely on the viral target and less on water types or method used (Cashdollar and Wymer, 2013). To date, no single efficient method to recover multiple viral pathogens from environmental waters has been developed. Adsorption of viral particles to charged microporous filters (electronegative and electropositive membranes and cartridges) followed by elution or desorption of the virus by a $\mathrm{pH}$ adjusted solution is perhaps the most common approach used in water analysis applications (Fong and Lipp, 2005; Fout et al., 1996; Haramoto et al., 2005; Katayama et al., 2002; Wyn-Jones and Sellwood, 1998; WynJones, 2007).

Ultrafiltration, i.e. tangential flow filtration (TFF) and hollow-fiber ultrafiltration, based on size exclusion or 
entrapment of viral particles to a filter matrix, has emerged as the most promising methods for virus concentration from large volumes of water (Gibson and Schwab, 2011; Hill et al., 2005; Olszewski et al., 2005; Polaczyk et al., 2008; Rhodes et al., 2011). Furthermore, these methods have been optimized for the simultaneous concentration of multiple microorganisms (e.g., enteric bacteria, protozoa, and viruses) from diverse water matrixes, including source and finished drinking water, tap water, surface water, and reclaimed water (Gibson and Schwab, 2011; Hill et al., 2007; Hill et al., 2005; Liu et al., 2012; Morales-Morales et al., 2003; Polaczyk et al., 2008). In addition, a new type of filtration media composed of highly electropositive nanoalumina $(\mathrm{AlOOH})$ fibers $(\sim 2 \mathrm{~nm}$ in diameter by $\sim 250$ $\mathrm{nm}$ in length) and microglass is currently available for concentrating EVs and other enteric viruses from large volumes of water (Gibbons et al., 2010; Ikner et al., 2011; Karim et al., 2009; Li et al., 2010). NanoCeram cartridge filters combine the benefits of standard pleated filters and nanotechnology (Karim et al., 2009; Li et al., 2010).

Cell culture (i.e., primary cell cultures, cell strains, and continuous cell lines) has been widely used for cultivation and isolation of viruses from environmental samples, especially viruses that are amenable to culture (e.g., EVs, adenoviruses, reoviruses, and rotaviruses) (Fout et al., 1996; Gerba et al., 2013). In fact, virus isolation in cell culture has long served as the "gold standard" for virus detection (Leland and Ginocchio, 2007; WHO, 2004, 2015a). However, EVs behave differently on different types of cultured cells and therefore the use of multiple appropriate cell lines is essential to increase yield and to improve the detection assay (Chonmaitree et al., 1988; Prim et al., 2013). Table 6 describes the susceptibilities of different cell lines commonly used for isolation of $\mathrm{EV}$ and $\mathrm{HPeV}$. Cytopathic effect (i.e., morphological changes in individual cells or groups of cells induced by virus infection and easily recognizable under a light microscope) is the simplest and most widely used criterion for enterovirus infectivity; however not all EVs, cause a cytopathic effect, and in these cases other methods must suffice (Condit, 2013; Gerba et al., 2013). Quantitative measures of infectious enterovirus in environmental samples have been performed by the plaque assay or various endpoint methods that measure virus infectivity but not the number of virus particles in a preparation, many of which may be noninfectious (Condit, 2013).

Table 6. The susceptibilities of different cell lines commonly used for isolation of Enteroviruses and Human Parechoviruses

\begin{tabular}{|c|c|c|c|c|c|c|c|}
\hline \multirow{3}{*}{ Cell Line } & \multicolumn{7}{|c|}{ Susceptibility to Viruses ${ }^{a}$} \\
\hline & \multirow{2}{*}{ Poliovirus } & \multicolumn{2}{|c|}{ Coxsackievirus } & \multirow{2}{*}{ Echovirus } & \multicolumn{3}{|c|}{ HPeV } \\
\hline & & Type $\mathbf{A}^{\mathbf{b}}$ & Type B & & 1 & 2 & 3 \\
\hline \multicolumn{8}{|l|}{ Monkey kidney } \\
\hline Rhesus & +++ & + & +++ & +++ & + & + & $u_{n k} k^{c}$ \\
\hline Cynomolgus & ++++ & + & +++ & +++ & + & + & unk \\
\hline Buffalo green (BGMK) & +++ & + & ++++ & ++ & + & + & unk \\
\hline African green (Vero) & +++ & + & +++ & ++ & + & + & unk \\
\hline LLCMK2 & +++ & + & +++ & +++ & ++ & ++ & $+++^{\mathrm{d}}$ \\
\hline \multicolumn{8}{|l|}{ Human } \\
\hline HeLa & +++ & + & +++ & + & + & + & unk \\
\hline Kidney (293) & +++ & + & ++ & +++ & ++ & ++ & - \\
\hline WI-38 & ++ & ++ & + & +++ & + & + & unk \\
\hline Embryonic lung (HELF) & +++ & ++ & + & +++ & + & + & unk \\
\hline MRC-5 & +++ & + & + & +++ & + & + & unk \\
\hline Rhabdomyosarcoma (RD) & +++ & $+++^{e}$ & + & +++ & + & + & - \\
\hline HEp-2 & +++ & + & +++ & + & ++ & ++ & - \\
\hline A549 & +++ & + & +++ & +++ & + & + & - \\
\hline HuT-292 & +++ & +++ & +++ & +++ & unk & unk & unk \\
\hline HT-29 & +++ & + & +++ & +++ & +++ & +++ & - \\
\hline $\begin{array}{l}\text { Super E-mix (combination of } \\
\text { BGMK-hDAF }^{\mathrm{f}} \text { and } \mathrm{Caco}^{\mathrm{g}} \text { ) }\end{array}$ & ++ & unk & ++++ & ++++ & ++ & ++ & unk \\
\hline
\end{tabular}

${ }^{\text {a }}$ Relative susceptibilities: + , minimally susceptible; ++++ , maximally susceptible; -, nonsusceptible; ${ }^{\mathrm{b}}$ Coxsackievirus $\mathrm{A} 1, \mathrm{~A} 19$, and A20 are not readily isolated; ' unk: unknown (no published reports). Some viruses are difficult to isolate even on minimally susceptible cell lines; ${ }^{\mathrm{d}}$ Improved yields after passage; ${ }^{\mathrm{e}}$ Many types of CV type A only grow in RD cells; ${ }^{\mathrm{f}} \mathrm{BGMK}-\mathrm{hDAF}$, BGMK cells expressing human decay-accelerating factor; ${ }^{\mathrm{g}} \mathrm{Caco}$, human colon adenocarcinoma cells.

No one cell line is capable of efficiently identifying the vast array of enteroviruses in sewage, thus underestimation is recognized for many studies.

Source: (Stellrecht et al., 2010) 
Numerous molecular biology-based detection methods for EVs in environmental concentrates have been developed during the last decades as an alternative to cell-culture method. Molecular biological detection of enteroviral genomic RNA by conventional reverse transcription polymerase chain reaction (RT-PCR) and by reverse transcription quantitative real-time PCR (qRT-PCR) has been widely used for direct detection and identification of human EVs in environmental water concentrates. Genusspecific primers against the highly conserved region of the 5' untranslated region (5'UTR) from all enterovirus genomes are broadly used for generic detection of a few copies of enteroviral RNA. Furthermore, the enterovirus 5' UTR PCR assay, also called pan-EV PCR, allows the detection of enterovirus serotypes that do not readily grow in cell culture standardly used in most laboratories and additional fastidious serotypes that that have been unculturable in all cells tested to date.

Highly specific identification of enterovirus serotypes can be achieved by RT-PCR and direct nucleotide sequencing of all or a portion of the genomic region that encodes capsid proteins especially VP1 (Oberste et al., 1999; Oberste et al., 2003; Kroneman et al., 2011; Nix et al., 2006; Oberste et al., 2006; Pallansch et al., 2013). These sequences can be submitted to an online tool at http://www.rivm.nl/mpf/enterovirus/typingtool/introduction that returns the genotype by comparison with a regularly updated sequence reference set of human Picornaviridae genera and enterovirus species and (sero)types (Kroneman et al., 2011).

Integrated cell culture and PCR (i.e., ICC-PCR) developed in the late 1980s still provides a reliable method for practical analysis and direct monitoring of environmental samples for EVs and other viral pathogens recovered from environmental samples (Amdiouni et al., 2012; Chapron et al., 2000; Choo and Kim, 2006; Lee et al., 2005; Reynolds, 2004; Reynolds et al., 1996). More recently, these techniques have been used in combination with viral metagenomics approaches for cell culture evaluation of the virologically quality of wastewater (Aw et al., 2014).

\subsection{Data on the Occurrence in the Environment}

Human EVs have been recovered worldwide from surface waters including coastal waters, rivers, streams, and lakes, from wastewaters, ground waters and finished drinking water (Boehm et al., 2003; Borchardt et al., 2007; Borchardt et al., 2012; Chapron et al., 2000; Donaldson et al., 2002; Fong and Lipp, 2005; Fout et al., 2003; Fuhrman et al., 2005; Gantzer et al., 1997; Griffin et al., 2003; Hamza et al., 2009; Hot et al., 2003; Jung et al., 2011; Pusch et al., 2005; Springthorpe and Sattar, 2007; Ye et al., 2012). EVs along with other culturable viruses (adenovirus, rotavirus, and reovirus) have been extensively monitored for regulatory purposes in the US in order to derive baseline data on the occurrence of viral agents in surface and ground waters (Fout et al., 1996). Due to their ubiquitous excretion in feces and frequent detection in untreated domestic wastewaters EVs are the best known viruses and commonly associated with water quality (Grabow, 2007; Rodriguez et al., 2012). The detection of EVs in sources of drinking water and recreational water bodies has been broadly accepted as a marker of a possible failure of the sanitation systems and as an indicator of the potential role of water in disease outbreaks (Hovi et al., 2007). Moreover, since the natural host for all human EVs is humans, the detection and quantification of amplifiable enterovirus genetic material in environmental waters has been proposed and used as a water quality assessment tool for tracking sources of human fecal pollution (Boehm et al., 2003; Fong et al., 2005; Wong et al., 2012).

\subsubsection{Occurrence in sewage}

The concentration and types of EVs and other picornaviruses in municipal waste waters (i.e., sewage) in different geographic locations, including highly polluted surface waters in areas where wastewater treatment is either inadequate or nonexistent, are shown in Table 7. 
Table 7. Occurrence of enteroviruses and other human picornaviruses in untreated sewage worldwide

\begin{tabular}{|c|c|c|c|c|c|}
\hline Area & $\begin{array}{l}\text { Period of } \\
\text { Study }\end{array}$ & $\begin{array}{l}\text { Information on } \\
\text { Collection }\end{array}$ & $\begin{array}{l}\text { Percentage Positive } \\
\text { (\# of Samples) }\end{array}$ & $\begin{array}{c}\text { Concentration Average } \\
\text { (Range), (GC/L, PFU/L, } \\
\text { MPN/L, IU/L) } \\
\end{array}$ & Reference \\
\hline Bolivia & 2012 & None & $\begin{array}{l}100 \% \\
10 / 10\end{array}$ & $\begin{array}{c}4.2 \mathrm{E}+02 \text { to } \\
6.2 \mathrm{E}+02 \mathrm{IU}^{\mathrm{b}} / \mathrm{L}\end{array}$ & Symonds et al., 2014 \\
\hline $\begin{array}{l}\text { China } \\
\text { (Guangzhou) }\end{array}$ & 2009 to 2012 & Liede & $\begin{array}{c}90 \% \\
216 / 240\end{array}$ & $\mathrm{NR}^{\mathrm{C}}$ & Zheng et al, 2013 \\
\hline $\begin{array}{l}\text { Côte d'Ivoire } \\
\text { (Abijan) }\end{array}$ & 2008 to 2009 & Yopougon, Abijan & $\begin{array}{c}44.1 \% \\
(30 / 68) \\
51.5 \% \\
(35 / 68)\end{array}$ & NR & Momou et al., 2013 \\
\hline $\begin{array}{l}\text { Côte d'Ivoire } \\
\text { (Abijan) }\end{array}$ & 2008 to 2009 & Yopougon, Abijan & $\begin{array}{c}39 \% \\
(27 / 68)\end{array}$ & 4.28 E+02 PFU/L & Momou et al., 2013 \\
\hline $\begin{array}{l}\text { Germany } \\
\text { (Leipzig) }\end{array}$ & 2002 to 2003 & Leipzig, Rosental & $\begin{array}{l}89 \% \\
(8 / 9)\end{array}$ & NR & Pusch et al., 2005 \\
\hline $\begin{array}{l}\text { Iran (Sistan- } \\
\text { Balouchestan, } \\
\text { Tehran, Fars } \\
\text { Province) }\end{array}$ & 2006 to 2007 & $\begin{array}{l}\text { Several villages in Sistan and } \\
\text { Balouchestan Province (Zabol, } \\
\text { Zahedan, Chabahar), city of } \\
\text { Tehran, and Fars Province }\end{array}$ & $\begin{array}{l}100 \% \\
(197 / 197)\end{array}$ & NR & Kargar et al., 2009 \\
\hline Israel & Jan to Aug 2013 & None & $\begin{array}{l}40.6 \% \\
(80 / 192)\end{array}$ & $\begin{array}{c}\text { from } 0 \text { to } 2.08 \mathrm{E}+07 \\
\text { PFU/L }\end{array}$ & Shulman et al., 2014 \\
\hline Israel & 1989 to 1997 & $\begin{array}{l}\text { Composite samples plus a } \\
\text { few grab samples and gauze } \\
\text { pad collections }\end{array}$ & $\begin{array}{c}>80 \% \\
(1779 / 2224)\end{array}$ & 0 to $250 \mathrm{PFU} / \mathrm{L}$ & Manor et al., 1999 \\
\hline $\begin{array}{l}\text { Italy } \\
\text { (Milan) }\end{array}$ & 2006 to 2012 & $\begin{array}{l}\text { Central-eastern Milan and in } \\
\text { the Milanese hinterland } \\
\text { (Peschiera Borromeo, Nosedo, } \\
\text { Nosedo Est) }\end{array}$ & $\begin{array}{c}96.8 \% \\
(311 / 321)\end{array}$ & NR & Battistone et al., 2014 \\
\hline $\begin{array}{l}\text { Japan } \\
\text { (Osaka, Kyoto, } 2 \\
\text { Saitama, Shiga, } \\
\text { Tokyo, Ibaraki) }\end{array}$ & 2003 to 2004 & Six WWTPs ${ }^{d}$ & $\begin{array}{l}100 \% \\
(72 / 72)\end{array}$ & $\sim 3 \mathrm{E}+02 \mathrm{GC} / \mathrm{e}$ & Katayama et al., 2008 \\
\hline $\begin{array}{l}\text { Japan } \\
\text { (Yamanashi } \\
\text { Prefecture) }\end{array}$ & 2011 to 2012 & None & $\begin{array}{l}71 \% \\
(10 / 14)\end{array}$ & $\begin{array}{l}4.47 \mathrm{E}+04 \text { to } 2.8 \mathrm{E} \\
\quad+06 \mathrm{GC} / \mathrm{L}\end{array}$ & $\begin{array}{l}\text { Haramoto and } \\
\text { Otagiri, } 2013\end{array}$ \\
\hline New Zealand & 2003 to 2004 & From across New Zealand & $\begin{array}{c}60 \% \\
(18 / 30) \\
100 \% \\
(30 / 30)\end{array}$ & $\begin{array}{c}5.0 \text { to } 8.3 \mathrm{E}+03 \mathrm{PFU} / \mathrm{L} \\
6.91 \mathrm{E}+02 \text { to } 4.67 \mathrm{E}+06 \mathrm{GC} / \mathrm{L}\end{array}$ & Hewitt et al., 2011 \\
\hline Singapore & 2007 & $\begin{array}{c}\text { Three water reclamation } \\
\text { plants }\end{array}$ & $\begin{array}{c}94 \% \\
(17 / 18)\end{array}$ & NR & Aw and Gin, 2010 \\
\hline $\begin{array}{l}\text { Slovak Republic } \\
\text { (Banska Bystrica, } \\
\text { Presov, Zilina, } \\
\text { Nitra, Kosice, } \\
\text { Trencin, Trnava, } \\
\text { Bratislava) }\end{array}$ & 2001 to 2011 & $\begin{array}{l}\text { Sewers from self-governing } \\
\text { Western, Central, Eastern } \\
\text { region }\end{array}$ & $\begin{array}{c}100 \% \\
(3744 / 3744)\end{array}$ & NR & Klement et al., 2013 \\
\hline $\begin{array}{l}\text { South Africa } \\
\text { (Pretoria and } \\
\text { Johannesburg) }\end{array}$ & 2001 to 2003 & $\begin{array}{c}\text { Daspoort Sewage Treatment } \\
\text { Plant, Pretoria and East } \\
\text { Rand Water Care Company, } \\
\text { Johannesburg }\end{array}$ & $\begin{array}{c}32 \% \\
(112 / 351) \\
\text { Enteroviruses } \\
25 \% \\
(88 / 351) \\
\text { NPEVs } \\
7.0 \% \\
(25 / 351) \\
\text { PV }\end{array}$ & NR & $\begin{array}{c}\text { Pavlov, 2006; } \\
\text { Pavlov et al., } 2005\end{array}$ \\
\hline South Africa & 2000 to 2002 & Selected Areas & $\begin{array}{c}42.5 \% \\
(43 / 100)\end{array}$ & NR & Ehlers, 2005 \\
\hline $\begin{array}{l}\text { Spain (Barcelona } \\
\text { and Girona) }\end{array}$ & 2001 to 2006 & Northern Spain & $\begin{array}{c}84 \% \\
(62 / 74)\end{array}$ & $\begin{array}{c}5.4 \mathrm{E}+03 \text { to } \\
3.7 \mathrm{E}+04 \mathrm{PFU} / \mathrm{L}\end{array}$ & $\begin{array}{c}\text { Contan-Longares et } \\
\text { al., } 2008\end{array}$ \\
\hline Taiwan & 2004 to 2005 & Hospital sewage & $\begin{array}{l}31 \% \\
(4 / 13)\end{array}$ & NR & Chen et al., 2008 \\
\hline & & & $\begin{array}{c}46 \% \\
(6 / 13)\end{array}$ & & \\
\hline
\end{tabular}




\begin{tabular}{|c|c|c|c|c|c|}
\hline Area & $\begin{array}{l}\text { Period of } \\
\text { Study }\end{array}$ & $\begin{array}{l}\text { Information on } \\
\text { Collection }\end{array}$ & $\begin{array}{l}\text { Percentage Positive } \\
\text { (\# of Samples) }\end{array}$ & $\begin{array}{c}\text { Concentration Average } \\
\text { (Range), (GC/L, PFU/L, } \\
\text { MPN/L, IU/L) }\end{array}$ & Reference \\
\hline $\begin{array}{l}\text { The Netherlands } \\
\text { (Apeldoorn) }\end{array}$ & s 1998 to 1999 & City of Apeldoorn & $\begin{array}{l}100 \% \\
(72 / 72)\end{array}$ & $1.4 \mathrm{E}+02$ to $8.33 \mathrm{E}+02 \mathrm{PFU} / \mathrm{L}$ & $\begin{array}{l}\text { Lodder and de Roda } \\
\text { Husman, } 2005\end{array}$ \\
\hline Tunisia & 2009 to 2010 & $\begin{array}{l}\text { Rural regions of Monastir and } \\
\text { Madhia governments, East } \\
\text { center part of Tunisia }\end{array}$ & $\begin{array}{l}30.2 \% \\
(52 / 172)\end{array}$ & NR & Ibrahim et al., 2014 \\
\hline $\begin{array}{l}\text { United Kingdom } \\
\text { (Edingburgh) }\end{array}$ & 2009 to 2010 & None & $\begin{array}{r}92.5 \% \\
(37 / 40)\end{array}$ & NR & Harvala et al., 2014 \\
\hline $\begin{array}{l}\text { USA } \\
\text { Milwaukee, } \\
\text { Wisconsin }\end{array}$ & 1994 to 2003 & None & $\begin{array}{c}88 \% \\
(94 / 107)\end{array}$ & $\begin{array}{c}2.37 \mathrm{E}+02 \text { to } \\
3.35 \mathrm{E}+03 \mathrm{MPN} / \mathrm{L}\end{array}$ & Sedmaket al., 2005 \\
\hline (MSA & 2008 to 2009 & Five WWTPs & (109\%) & $\begin{array}{c}3.0 \mathrm{E}+02 \text { to } 1.2 \mathrm{E}+06 \mathrm{GC} / \mathrm{L} \\
8.0 \text { to } 5.0 \mathrm{E}+02 \mathrm{MPN} / \mathrm{L}\end{array}$ & $\begin{array}{c}\text { Simmons and } \\
\text { Xagoraraki, 2011b }\end{array}$ \\
\hline (OSA & 2008 to 2010 & Composited grab samples & $(15 \%$ /9) & $2.4 \mathrm{E}+02$ to $2.9 \mathrm{E}+05 \mathrm{GC} / \mathrm{L}$ & Francy et al., 2012 \\
\hline $\begin{array}{l}\text { USA } \\
\text { (Southern } \\
\text { Arizona) }\end{array}$ & 2011 to 2012 & & (1299\%) & $\begin{array}{c}\mathrm{EV}: 1 \mathrm{E}+03 \text { to } 1 \mathrm{E}+06 \mathrm{GC} / \mathrm{L} \\
\text { AiV: } 9.7 \mathrm{E}+04 \text { to } 2.7 \mathrm{E}+06 \mathrm{GC} / \mathrm{L}\end{array}$ & Kitajima et al., 2014b \\
\hline $\begin{array}{l}\text { USA } \\
\text { (Southern } \\
\text { Arizona) }\end{array}$ & 2011 to 2012 & & $\begin{array}{l}25 \% \\
(6 / 24)\end{array}$ & Max $3.24 \mathrm{E}+05 \mathrm{GC} / \mathrm{L}$ & Kitajima et al., 2015 \\
\hline $\begin{array}{l}\text { USA } \\
\text { (Southern } \\
\text { Arizona) }\end{array}$ & 2011 to 2012 & Two WWTPs & $\begin{array}{c}46 \% \\
(11 / 24)\end{array}$ & $2.32 \mathrm{E}+03$ to $2.28 \mathrm{E}+05 \mathrm{GC} / \mathrm{L}$ & Kitajima et al., 2014a \\
\hline $\begin{array}{l}\text { Venezuela } \\
\text { (Caracas) }\end{array}$ & 2007 to 2008 & Domestic sewers & $\begin{array}{l}75 \% \\
(9 / 12)\end{array}$ & NR & $\begin{array}{l}\text { Rodriguez-Diaz } \\
\text { et al., } 2009\end{array}$ \\
\hline
\end{tabular}

aMethods used in the different studies. Bolivia: Adsorption/elution electronegative membranes/Cell culture, results reported in infection units per liter. China: Adsorption/elution electronegative membranes; cell culture-RT-PCR. Côte d'Ivoire: Two-phase separation procedure (PEG-6000 and Dextran T40) RT-PCR and cell culture-RT-PCR. Results reported as plaque forming units per liter. Côte d'Ivoire: Two-phase separation procedure followed by cell culture and typing by seroneutralization assay (Lim Benyesh-Melnick neutralizing antibody pools A through H) and RT-PCR. PVs identified by ELISA and Intratypic differentiation testing by PCR. Germany: Ultracentrifugation and nested RTPCR. Iran: Two-phase separation procedure [cell culture - seroneutralization assay (Lim Benyesh-Melnick neutralizing antibody pools A through $\mathrm{H})$. Israel: Two-phase separation procedure for composite samples and cell culture. Italy: Two-phase separation procedure followed by cell culture - RT-PCR. Enterovirus typing by seroneutralization assay using Lim Benyesh-Melnick neutralizing antibody pools A through H. RT-PCR. PVs: ELISA and ITD testing by PCR. Japan: Adsorption/elution electronegative membranes [RT-qPCR]. New Zealand: Centrifugation/flocculation followed by hydroextraction with Polyethelene glycol - NaCl, cell culture, RT-qPCR. Singapore: HydroextractionPolyethelene glycol [RT-PCR]. Slovak Republic: Two-phase separation procedure (PEG-6000 and Dextran T40)[cell culture seroneutralization assay (Lim Benyesh-Melnick neutralizing antibody pools A through H)]. South Africa: Hydroextraction: Polyethelene glycol 6000 and sodium chloride [cell culture -RT-multiplex PCR]. South Africa : Glass wool adsorption-elution technique [cell culture - RTPCR]. Spain: Direct filtration through $0.22 \mu \mathrm{m}$-pore-size low protein binding polyether sulfone membrane filter [cell culture]. Taiwan: Adsorption/elution electronegative membranes [RT-PCR] [nested RT-PCR]. The Netherlands: Adsorption-elution electronegative cartridge (Nominal $1.2 \mu \mathrm{m}$ pore-sized filter) [cell culture]. Tunisia: Prefiltration/flocculation followed by hydroextraction with Polyethelene glycol [RTPCR]. United Kingdom: Centrifugation/Filtration [RT-PCR]. United States of America: Organic flocculation (US EPA ICR virus protocol) [cell culture- Lim Benyesh-Melnick neutralizing antibody pools A through $\mathrm{H}$ ]. USA: Adsorption-elution electropositive cartridge (Zeta Plus Virosorb 1 MDS) [RT-qPCR]. USA: Glass wool adsorption-elution technique, RT-qPCR. USA: Adsorption/elution electronegative membranes [RT-qPCR]. USA: Adsorption/elution electronegative membranes [RT-qPCR]. USA: Adsorption/elution electronegative membranes[RT-qPCR]. Venezuela: Ultracentrifugation [RT-PCR].

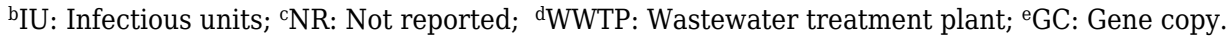

Members of the genus Enterovirus are universally distributed among human populations and therefore are always found in sewage waters worldwide (Gerba et al., 2013; Pallansch et al., 2013).
Quantitative estimation of human EVs and other picornaviruses (i.e., viral load) in domestic wastewaters (i.e., primary source of human EVs and enteric picornaviruses to the environment) from different regions may vary due to differences and limitations of the methods 
used for recovery and detection of viruses in water, differences in the viral load that may exist in human populations for each enteric virus, and daily plus seasonal fluctuations of viruses in human sewage. Nevertheless, the assessment of the total and infectious viral load in untreated and treated domestic wastewaters as well as the identification of virus types are critical to understand the fate of viral pollutants in the environment and to estimate the potential health risks from waterborne viral pathogens from discharges to waters used for recreation, shellfish farming or as sources of drinking water (de Roda Husman and Bartram, 2007; Gerba et al., 2013; Gibson, 2014; Rao et al., 1986; Symonds et al., 2009). Quantitative information of the virus concentration in various types of water, including quantitative data of the inactivation and removal of pathogenic viruses by water and wastewater treatment processes, are essential parameters for the quantitative microbial risk assessment (QMRA) process, the new concept for evaluating microbial safety of drinking water and wastewater (Haas et al., 1993; Haas et al., 1999; Hijnen et al., 2006; Mena, 2007; Soller, 2006).

Screening of waste waters for human viruses in multiple geographical areas has revealed the presence of newly described genera of the Picornaviridae family, i.e., Cosavirus, Cardiovirus, Salivirus, Kobuvirus (Alcala et al., 2010; Blinkova et al., 2009; Haramoto and Otagiri, 2013; Kitajima et al., 2014b; Kitajima et al., 2015). More recent, deep-sequencing analysis of viral metagenomes from sewage and sewage sludge (also known as sewage viromes) has indicated that these novel human picornaviruses can be found in most cases at relatively higher abundance and occurrence than members of the Enterovirus genus (Aw et al., 2014; Bibby and Peccia, 2013; Cantalupo et al., 2011; $\mathrm{Ng}$ et al., 2012). Taken together, these studies have demonstrated the importance of targeted molecular assays and unbiased high-throughput sequencing (i.e., metagenomics viral pathogen detection technologies) to the study of virus diversity in waste waters and to monitor shedding of known and newly characterized viral human pathogens on a population level scale.

\subsubsection{Occurrence in sludge}

Numerous studies conducted during the last two decades have evaluated the occurrence of EVs in biosolids and the efficiency of sludge treatment on the reduction of these and other enteric viruses (Goddard et al., 1981; Goyal et al., 1984; Guzman et al., 2007; Monpoeho et al., 2001; Pourcher et al., 2005; Schwartzbrod and Mathieu, 1986; Sidhu and Toze, 2009; Soares et al., 1994; Straub et al., 1994; USEPA, 1988). Despite the extreme heterogeneity of sludge samples and variations in sampling processing methods, these studies demonstrated the occurrence of infectious EVs and other enteric viruses in treated biosolids.

Soares et al. (Soares et al., 1994) evaluated the occurrence of EVs in undigested and anaerobically digested sludge. For undigested sludge the concentration of EVs varied between 4.36 MPN/g (most probable number per gram dry weight) to $7.00 \times 10^{2} \mathrm{MPN} / \mathrm{g}$ with geometric average of $3.29 \times 10^{1} \mathrm{MPN} / \mathrm{g} \pm 0.0044$. For anaerobically digested sludge the concentration varied from $<0.0062$ $\mathrm{MPN} / \mathrm{g}$ to $2.52 \times 10^{2} \mathrm{MPN} / \mathrm{g}$ with a geometric average of 1.61 $\mathrm{MPN} / \mathrm{g} \pm 0.02$. Removal of EVs during sludge treatment ranged from $0.5 \log _{10}$ to $>3 \log _{10}$ with a geometric mean 1 $\log _{10}$. The study revealed that despite sludge treatment the concentration of EVs in anaerobically digested sludge could exceed $10^{2} \mathrm{MPN} / \mathrm{g}$ and therefore additional treatment was required in order to reduce the concentration of EVs to levels established for land application in the study area.

Monpoeho et al. (2001) evaluated several viral extraction techniques for simultaneous detection of EV genomes (number of copies per $10 \mathrm{~g}$ of dry matter) and infectious particles (most-probable-number cytopathogenic units [MPNCU]/10 $\mathrm{g}$ of dry matter) in different types of sludge samples. The concentration of EVs detected varied considerably from one sample to another. For primary sludge the concentrations varied from $<0.3$ to $2.24 \times 10^{2} \mathrm{MPNCU} / \mathrm{g}$ and from $<40$ to $3.84 \times 10^{4}$ genome copies/g (dry weight). The mean concentrations detected in primary sludge were $45.7 \mathrm{MPNCU} / \mathrm{g}$ and $1.37 \times 10^{4}$ genome copies/g. The equivalent values were $2.9 \mathrm{MPNCU} / \mathrm{g}$ and $9.36 \times 10^{2}$ copies $/ g$ in activated sludge, $0.9 \mathrm{MPNCU} / \mathrm{g}$ and $1.06 \times 10^{3}$ copies/g in thickened sludge, and $0.7 \mathrm{MPNCU} / \mathrm{g}$ and $4.8 \times 10^{3}$ copies/g in digested sludge. According to these results, from primary sludge to activated sludge the concentrations of virus decreased by a factor of 16 in terms of infectivity and by a factor of 15 in terms of genomes. From activated sludge to thickened sludge viruses decreased by a factor of 3 in terms of infectivity but remained unchanged in terms of genomes. Finally, from thickened sludge to digested sludge they decreased slightly, by a factor of 1.3, in terms of infectivity and increased by a factor of 4.5 in terms of genomes. The study provided a rapid sludge testing protocol capable of determining concentrations of viral genomes and proportion of infectious virus particles in sludge samples.

Wong et al. (2010) investigated the occurrence and the quantitative levels of human EVs and other enteric viruses (human adenovirus, NoVGGI, NovGGII , and hepatitis A virus) in class B mesophilic anaerobically digested (MAD) biosolid samples using molecular (qPCR) and cell culture methods. In this study, the levels of human adenoviruses were significantly higher than the levels of other enteric viruses and they were also detected more frequently than other enteric viruses. The average levels of EVs and adenoviruses in the MAD biosolids were $1.9 \times 10^{4}$ copies/g and $5.0 \times 10^{5}$ copies/g, respectively. The average level of human NoVs corresponded to $5 \times 10^{4}$ copies/g (NV GGI) and $1.5 \times 10^{5}$ copies/g (NV GGII). The ICC-PCR assays demonstrated the occurrence of infectious adenoviruses and EVs in the biosolid samples thereby indicating the limited inactivation effectiveness of MAD treatment as revealed in previous studies (Monpoeho et al., 2004; Soares et al., 1994). This study also highlighted the importance of monitoring for additional human pathogenic viruses (adenoviruses, NoVs) considering their frequent occurrence and levels reported in biosolids. Indeed, due to the large potential pathogen diversity in sewage sludge and biosolids, continuous surveillance of biosolids for the culturable and infective content of a broad diversity of 
pathogens may be required to understand potential risks (Viau et al., 2011).

Reduction/inactivation of EVs in biosolids is discussed in Part 3.1.8 of Section 3.0 Monitoring the occurrence of infectious EVs in biosolids is required to assess pathogen disinfection efficacy and compliance with pathogen landapplication standards. Furthermore, quantitative data from pathogen monitoring can be used to assess the infection risk associated with biosolids pathogen exposure. Class-Btreatment processes must yield virus reduction levels (i.e., $\log$ reduction value) established for each biosolids disinfection process (i.e., 0.5 - 2 logs) (USEPA, 1999). The European limit value for virus concentration in biosolids is 3 MPNCU (for most probable cytopathic units) per $10 \mathrm{~g}$ of dry matter. More recently, QMRA of biosolids exposure based on new pathogen data has demonstrated that the tradition of monitoring pathogen quality by Salmonella spp. and concentration of EVs underestimates the infection risk of pathogens contained in the biosolids (to the public), and that a rigorous biosolids pathogen treatment process is the most efficient method of reducing pathogen exposure and infection risk (Viau et al., 2011). Indeed, the use of improved risk assessment methods has been recommended to supplement technological approaches to establishing regulatory criteria for pathogens in biosolids (National Research Council, 2002). In the United Kingdom, the use of sewage sludge as a soil enhancer and fertilizer on agricultural land remains the environmentally favored option, with around $80 \%$ being applied to agricultural land. In Australia and New Zealand strict state and national guidelines specify the way in which specific biosolids can be used.

\subsubsection{Occurrence in drinking water}

EVs were detected in treated drinking water from supplies that had been treated and disinfected according to international specifications for the production of safe drinking water in South Africa (Ehlers et al., 2005; Vivier et al., 2004). The frequency of detection ranged from 11 to $18.7 \%$ and CV-B was the EV predominantly found in drinking water samples. In Egypt, two conventional drinking water treatment plants differing in treatment capacity were investigated for the occurrence of EVs and other enteric viruses. EVs were found in finished water samples and the infective EV count ranged between 1.6 and 33.3 plaque forming unit (PFU)/L (Ali et al., 2004). These viruses were also detected in the distribution system as a result of inadequate water pipe connections. Similarly, EVs were detected in finished water samples collected from seven conventional water treatment plants in the Montreal, Quebec, area that ranged in capacity from 2.4 to 26.4 millions of gallons per day and produced finished water essentially free of indicator bacteria. The frequency of detection of cytopathogenic viruses expressed as MPNCU/L was $7 \%$ (11 of 155) and the average density was 0.0006 MPNCU/L with the highest virus density measured corresponding to 0.02 MPNCU/L (Payment et al., 1985b). All viruses isolated were EVs (types 1, 2, and 3 PVs, CVB3, CVB4, CVB5, Echovirus 7, and untyped picornaviruses). EVs were also detected in $47.8 \%$ of tap water samples collected from different locations in three urban areas in Seoul, Korea (Lee and Kim, 2002). The level of infectious EVs was always below 10 MPN per 1000 Lbut the frequency of detection was considerably high compared to previous studies.

\subsubsection{Occurrence in coastal waters}

Human EVs have been found in varying concentrations in marine coastal waters as demonstrated by numerous research studies conducted from early 2000 around the world (Table 8). Previous studies from 1970s - 1980s on viruses in coastal waters focused on EVs due to the ability to detect these viruses using standard-cell culture monolayer methods. The level of EVs reported per liter of sample analyzed ranged from 0.007 to $2.6 \mathrm{PFU} ; 0.05$ to 16 TCID $_{50} ; 0.05$ to 6.5 MPNCU as summarized by Bosch et al. (2005). Recent investigations have introduced PCR detection and quantification of enterovirus genomes by qPCR followed by molecular characterization of the EV types including identification of other human picornaviruses by amplicon sequencing. Types 1, 2 and 3 PVs; coxsackievirus, echovirus, EVs and other human picornaviruses such as HPeVs have been isolated from marine coastal waters. The concentrations reported in the different studies included in Table 8 vary as a result of the level of sewage treatment provided and the methods used to concentrate and detect the viruses.

Table 8. Occurrence of enteroviruses in coastal waters

\begin{tabular}{|c|c|c|c|c|c|c|}
\hline Area & $\begin{array}{c}\text { Sample } \\
\text { Description }\end{array}$ & $\begin{array}{c}\text { Enterovirus } \\
\text { Type } \\
\text { Identified }\end{array}$ & $\begin{array}{l}\text { Concentration } \\
\text { Technique and } \\
\text { Detection Assay } \\
\text { [Cell Culture or RT- } \\
\text { PCR/RT-qPCR }\end{array}$ & $\begin{array}{l}\text { Percent } \\
\text { Positive } \\
\text { (\# of } \\
\text { Samples) }\end{array}$ & $\begin{array}{c}\text { Concentration } \\
\text { Average } \\
\text { (Range), } \\
\left(\mathrm{GC} / \mathbf{L}^{\mathrm{a}}, \mathbf{P F U} / \mathbf{L}^{\mathrm{b}},\right. \\
\mathrm{MPN} / \mathbf{L}^{\mathrm{c}}, \mathrm{IU}^{\mathrm{d}} / \mathbf{L}^{\mathrm{d}} \text { ) } \\
\end{array}$ & Reference \\
\hline $\begin{array}{l}\text { China } \\
\text { (Tianging) }\end{array}$ & $\begin{array}{l}\text { Winter seawater } \\
\text { along Tianging } \\
\text { coast of Bojai Bay }\end{array}$ & $\begin{array}{c}\text { Poliovirys type } \\
2\end{array}$ & $\begin{array}{c}\text { Centricon plus-70 } \\
\text { centrifugal filter device } \\
\text { (100-kDa molecular } \\
\text { weight cutoff membrane) } \\
\text { [RT-qPCR] }\end{array}$ & $\begin{array}{l}100.0 \% \\
(10 / 10)\end{array}$ & $\begin{array}{c}1.7 \mathrm{E}+06 \text { to } \\
6.3 \mathrm{E}+07 \mathrm{GC} / \mathrm{L}\end{array}$ & $\begin{array}{l}\text { Zhang et al., } \\
2010\end{array}$ \\
\hline
\end{tabular}




\begin{tabular}{|c|c|c|c|c|c|c|}
\hline Area & $\begin{array}{c}\text { Sample } \\
\text { Description }\end{array}$ & $\begin{array}{c}\text { Enterovirus } \\
\text { Type } \\
\text { Identified }\end{array}$ & $\begin{array}{l}\text { Concentration } \\
\text { Technique and } \\
\text { Detection Assay } \\
\text { [Cell Culture or RT- } \\
\text { PCR/RT-qPCR }\end{array}$ & $\begin{array}{l}\text { Percent } \\
\text { Positive } \\
\text { (\# of } \\
\text { Samples) }\end{array}$ & $\begin{array}{c}\text { Concentration } \\
\text { Average } \\
\text { (Range), } \\
\left(\text { GC/L }, \text { PFU/L }{ }^{\mathrm{b}},\right. \\
\left.\text { MPN/L }, \mathbf{L}^{\mathrm{c}} / \mathbf{L}^{\mathrm{d}}\right)\end{array}$ & Reference \\
\hline $\begin{array}{l}\text { Italy } \\
\text { (Venice) }\end{array}$ & $\begin{array}{l}\text { Surfzone at Lido } \\
\text { Beach }\end{array}$ & $\mathrm{NR}^{\mathrm{e}}$ & $\begin{array}{c}\text { Adsorption/elution } \\
\text { electronegative } \\
\text { membranes [RT-qPCR] }\end{array}$ & $\begin{array}{l}88.2 \% \\
(15 / 17)\end{array}$ & $\begin{array}{c}2.0 \text { to } \\
1.61 \mathrm{E}+03 \mathrm{GC} / \mathrm{L}\end{array}$ & Rose et al., 2006 \\
\hline $\begin{array}{l}\text { Japan } \\
\text { (Fujisawa } \\
\text { City and } \\
\text { Tokyo) }\end{array}$ & $\begin{array}{l}\text { Summer sampling: } \\
\text { Enoshima Beach } \\
\text { (Kanagawa } \\
\text { Prefecture) } \\
\text { Winter sampling: } \\
\text { Tokyo Bay } \\
\text { (Daiba Kaihin Park } \\
\text { and Kasai Kaihin } \\
\text { Park) }\end{array}$ & NR & $\begin{array}{l}\text { Adsorption/elution } \\
\text { electronegative } \\
\text { membranes } \\
\text { [cell culture-RT-PCR] }\end{array}$ & $\begin{array}{c}66.6 \% \\
(4 / 6)^{f}\end{array}$ & NR & $\begin{array}{c}\text { Katayama et al., } \\
2002\end{array}$ \\
\hline $\begin{array}{l}\text { Japan } \\
\text { (Kanagawa } \\
\text { Prefecture) }\end{array}$ & Tokyo Bay & NR & $\begin{array}{c}\text { Adsorption/elution } \\
\text { electronegative } \\
\text { membranes } \\
\text { [RT-PCR and cell culture } \\
\text { PCR] }\end{array}$ & $\begin{array}{c}24.4 \% \\
(11 / 45)^{g} \\
40.6 \% \\
(26 / 64)^{\mathrm{h}}\end{array}$ & NR & $\begin{array}{c}\text { Katayama et al., } \\
2004\end{array}$ \\
\hline $\begin{array}{l}\text { Spain } \\
\text { (Barcelona) }\end{array}$ & $\begin{array}{c}\text { Marine beaches in } \\
\text { the metropolitan } \\
\text { area }\end{array}$ & NR & $\begin{array}{l}\text { Adsorption/elution glass } \\
\text { powder VIRADEN } \\
\text { method } \\
\text { cell culture } \\
\text { [RT-PCR] }\end{array}$ & $\begin{array}{c}50 \% \\
(10 / 10)^{\mathrm{i}} \\
20.0 \% \\
(4 / 20)^{\mathrm{j}}\end{array}$ & $\begin{array}{c}1 \text { to } 1.58 \mathrm{E}+02 \\
\text { PFU/10L }\end{array}$ & $\begin{array}{l}\text { Moce-Llivina et } \\
\text { al., } 2005\end{array}$ \\
\hline Spain & $\begin{array}{l}\text { Seawater samples } \\
\text { collected during } \\
\text { bathing season } \\
\text { (June through } \\
\text { September) }\end{array}$ & $\begin{array}{l}\text { CV: } 100 \%(\mathrm{CV}- \\
\text { B1 } 85.7 \% \text {; CV- } \\
\text { B4 14.3\%)/E }\end{array}$ & $\begin{array}{l}\text { VIRADEN method } \\
\text { (filtration and } \\
\text { quantification of viruses } \\
\text { adsorbed onto } 3 \mu \mathrm{m}- \\
\text { pore-size cellulose } \\
\text { nitrate membrane filters) } \\
\text { [cell culture] }\end{array}$ & $\begin{array}{c}63.3 \% \\
(13 / 21)\end{array}$ & $\begin{array}{l}\text { Maximum } 1.3 \\
\text { PFU/L }\end{array}$ & $\begin{array}{c}\text { Costan-Longares } \\
\text { et al., } 2008\end{array}$ \\
\hline $\begin{array}{l}\text { USA } \\
\text { (Sarasota, } \\
\text { Florida) }\end{array}$ & $\begin{array}{l}\text { Coastal waters off } \\
\text { west Florida }\end{array}$ & $\begin{array}{l}\text { Echovirus } 20 \\
\text { and 24; } \\
\text { poliovirus }\end{array}$ & $\begin{array}{l}\text { Adsorption/elution } \\
\text { electronegative } \\
\text { cartridges (Filterite) }\end{array}$ & $\begin{array}{c}25 \% \\
(11 / 24)\end{array}$ & $\begin{array}{l}0.17 \text { to } 0.59 \\
\text { IU/100 L }\end{array}$ & $\begin{array}{l}\text { Lipp et } \\
\text { al., 2001a }\end{array}$ \\
\hline USA & $\begin{array}{l}\text { Nearshore waters } \\
\text { Florida Keys }\end{array}$ & NR & $\begin{array}{c}\text { Adsorption/elution } \\
\text { electronegative } \\
\text { cartridges (Filterite) } \\
\text { [RT-PCR] }\end{array}$ & $\begin{array}{l}93.3 \% \\
(14 / 15)\end{array}$ & NR & $\begin{array}{l}\text { Lipp et al., } \\
\text { 2001b }\end{array}$ \\
\hline $\begin{array}{l}\text { USA } \\
\text { (Charlotte } \\
\text { Harbor } \\
\text { estuary, } \\
\text { Florida) }\end{array}$ & NR & NR & $\begin{array}{c}\text { Adsorption/elution } \\
\text { electronegative } \\
\text { cartridges (Filterite) [cell } \\
\text { culture] }\end{array}$ & $\begin{array}{l}21.8 \% \\
(7 / 32)\end{array}$ & $\begin{array}{c}1.0 \mathrm{E}+02 \text { to } \\
2.0 \mathrm{E}+02 \mathrm{MPN} / \mathrm{L}\end{array}$ & $\begin{array}{l}\text { Lipp et al., } \\
\text { 2001b }\end{array}$ \\
\hline USA & $\begin{array}{c}\text { Key West and Dry } \\
\text { Tortugas (Florida } \\
\text { Keys) }\end{array}$ & $\begin{array}{c}\text { Coxsackievirus } \\
\text { A9, } \\
\text { Coxsackievirus } \\
\text { A16, and } \\
\text { Poliovirus Sabin } \\
\text { type } 1\end{array}$ & $\begin{array}{l}\text { Vortex flow filtration } \\
\text { (100kD filter) Membrex } \\
\text { Benchmark System } \\
\text { (Membrex Inc., Garfield, } \\
\text { NJ, USA). } \\
\text { [RT-PCR] }\end{array}$ & $\begin{array}{l}60.0 \% \\
(9 / 15)\end{array}$ & $9.3 \mathrm{E}+02 \mathrm{GC} / \mathrm{L}$ & $\begin{array}{l}\text { Donaldson et al., } \\
2002\end{array}$ \\
\hline $\begin{array}{l}\text { USA } \\
\text { (Avalon } \\
\text { Bay, } \\
\text { Catalina } \\
\text { Island, } \\
\text { California) }\end{array}$ & $\begin{array}{c}\text { Offshore, bay, } \\
\text { shoreline, and } \\
\text { subsurface samples }\end{array}$ & NR & $\begin{array}{l}\text { Adsorption/elution glass } \\
\text { fiber filters [RT-qPCR] }\end{array}$ & $\begin{array}{l}13.6 \% \\
(3 / 22)\end{array}$ & NR & $\begin{array}{l}\text { Boehm et al., } \\
2003\end{array}$ \\
\hline $\begin{array}{l}\text { USA } \\
\text { (Key West, } \\
\text { Florida) }\end{array}$ & $\begin{array}{l}\text { Upper, Middle, and } \\
\text { Lower Keys }\end{array}$ & NR & $\begin{array}{l}\text { Adsorption/elution } \\
\text { electronegative } \\
\text { cartridges (Filterite) } \\
\text { [cell culture] }\end{array}$ & $\begin{array}{c}33.3 \% \\
(2 / 6)\end{array}$ & $\begin{array}{c}\text { 1.13E-01 to } \\
1.26 \mathrm{E}-01 \mathrm{PFU} / \mathrm{L}\end{array}$ & Wetz et al., 2004 \\
\hline
\end{tabular}




\begin{tabular}{|c|c|c|c|c|c|c|}
\hline Area & $\begin{array}{c}\text { Sample } \\
\text { Description }\end{array}$ & $\begin{array}{c}\text { Enterovirus } \\
\text { Type } \\
\text { Identified }\end{array}$ & $\begin{array}{l}\text { Concentration } \\
\text { Technique and } \\
\text { Detection Assay } \\
\text { [Cell Culture or RT- } \\
\text { PCR/RT-qPCR }\end{array}$ & $\begin{array}{l}\text { Percent } \\
\text { Positive } \\
\text { (\# of } \\
\text { Samples) }\end{array}$ & $\begin{array}{l}\text { Concentration } \\
\text { Average } \\
\text { (Range), } \\
\left(\text { GC/L }{ }^{\mathrm{a}}, \mathbf{P F U} / \mathbf{L}^{\mathrm{b}}\right. \\
\left.\text { MPN/L }, \mathbf{I U} / \mathbf{L}^{\mathrm{d}}\right)\end{array}$ & Reference \\
\hline $\begin{array}{l}\text { USA } \\
\text { (San } \\
\text { Diego, } \\
\text { California) }\end{array}$ & $\begin{array}{c}\text { Surfzone adjacent } \\
\text { to the Tijuana river } \\
\text { mouth, Imperial } \\
\text { Beach pier }\end{array}$ & $\begin{array}{c}\text { Echovirus 6, 11, } \\
\text { and 30; } \\
\text { Coxsackievirus } \\
\text { A5, Enterovirus } \\
\text { B, Poliovirus } \\
\text { SL-1, SL2, and } \\
\text { SL-3 }\end{array}$ & $\begin{array}{l}\text { Adsorption/elution } \\
\text { electronegative } \\
\text { membranes } \\
\text { [RT-qPCR] }\end{array}$ & $\begin{array}{c}100.0 \% \\
(7 / 7)^{1} \\
85.7 \% \\
(6 / 7)^{\mathrm{m}}\end{array}$ & $\begin{array}{c}3.0 \mathrm{E}+02 \text { to } \\
4.42 \mathrm{E}+04 \mathrm{GC} / \mathrm{L}^{1} \\
7.0 \mathrm{E}+01 \text { to } \\
3.75 \mathrm{E}+03 \mathrm{GC} / \mathrm{L}^{\mathrm{m}}\end{array}$ & $\begin{array}{l}\text { Gersberg et } \\
\text { al., } 2006\end{array}$ \\
\hline $\begin{array}{l}\text { USA } \\
\text { (Santa } \\
\text { Catalina } \\
\text { Island, } \\
\text { California) }\end{array}$ & $\begin{array}{l}\text { Nearshore waters } \\
\text { Avalon Beach ( } 72- \\
\text { hour sampling) }\end{array}$ & NR & $\begin{array}{c}\text { Adsorption/elution } \\
\text { electronegative } \\
\text { membranes [ } 1 \mathrm{~L}] \\
\text { [RT-PCR] }\end{array}$ & $\begin{array}{l}100.0 \% \\
(20 / 20)\end{array}$ & NR & $\begin{array}{l}\text { Boehm et al., } \\
2009\end{array}$ \\
\hline $\begin{array}{l}\text { USA } \\
\text { (Honolulu, } \\
\text { Hawaii) }\end{array}$ & $\begin{array}{l}\text { Coastal waters, } \\
\text { Island of Oahu }\end{array}$ & NR & $\begin{array}{l}\text { Adsorption/elution } \\
\text { electronegative } \\
\text { membranes } \\
\text { [RT-PCR] }\end{array}$ & $\begin{array}{c}50.0 \% \\
(11 / 22)\end{array}$ & NR & $\begin{array}{l}\text { Connell et } \\
\text { al., } 2012\end{array}$ \\
\hline $\begin{array}{l}\text { Venezuela } \\
\text { (Cumana) }\end{array}$ & $\begin{array}{l}\text { Nearshore coastal } \\
\text { waters northeast } \\
\text { Caribbean coast }\end{array}$ & $\begin{array}{l}\text { Echovirus 6, } \\
\text { Poliovirus SL-1, } \\
\text { Parechovirus }\end{array}$ & $\begin{array}{c}\text { Adsorption/elution } \\
\text { electronegative } \\
\text { membranes[RT-qPCR] } \\
\text { [ICC-RT-qPCR] }\end{array}$ & $\begin{array}{c}46.6 \% \\
(14 / 30)^{\mathrm{n}} \\
33.3 \% \\
(10 / 30)^{\circ}\end{array}$ & $\begin{array}{l}5.3 \mathrm{E}+03 \text { to } \\
3.9 \mathrm{E}+04 \mathrm{GC} / \mathrm{L}\end{array}$ & $\begin{array}{l}\text { Betancourt et } \\
\text { al., } 2015\end{array}$ \\
\hline \multicolumn{7}{|c|}{$\begin{array}{l}{ }^{\mathrm{a}} \mathrm{GC} / \mathrm{L} \text { : Genome copies per liter; }{ }^{\mathrm{b}} \mathrm{PFU} / \mathrm{L} \text { : Plaque forming units per liter; }{ }^{\mathrm{c}} \mathrm{MPN} / \mathrm{L} \text { : Most probable number per liter } \\
{ }^{\mathrm{d}} \mathrm{IU} / \mathrm{L} \text { : Infectious units per liter; }{ }^{\mathrm{e}} \mathrm{NR} \text { : Not reported; }{ }^{\mathrm{f}} \text { Enoshima Beach (summer), none detected in Tokyo Bay (winter) } \\
\text { } \text { Samples positive by RT-PCR; }{ }^{\mathrm{h}} \text { Samples positive by cell culture - PCR; }{ }^{\mathrm{i}} \text { Samples positive by cell culture; }{ }^{\mathrm{j}} \text { Samples positive by } \\
\text { RT-PCR; }{ }^{\mathrm{k}} \text { Geometric mean } 3.6 \mathrm{E}-01 \mathrm{PFU} / \mathrm{L} ;{ }^{\mathrm{l}} \text { Wet weather surf zone; }{ }^{\mathrm{m}} \text { Wet weather at Imperial Beach pier; }{ }^{\mathrm{n}} \text { Samples positive } \\
\text { by RT-qPCR; }{ }^{\circ} \text { Samples positive by cell culture RT-qPCR. }\end{array}$} \\
\hline
\end{tabular}

Solid-associated virions in marine waters are protected from inactivation by environmental stressors (e.g., sunlight irradiation, increasing temperatures, and microbial enzymatic degradation), can be transported long distances after discharge in surficial sediment pore water, and particle-bound virions in sediments can be easily resuspended by mild turbulence and water movements including tidal currents, patterns of water circulation, prevailing winds, storm action, dredging, boating and in coastal and shelf environments (Bosch et al., 2006; Dupuy et al., 2014; Gerba, 2007; Hurst and Murphy, 1996; Pianetti et al., 2007; Rao et al., 1986).

\subsubsection{Regulatory considerations for coastal waters}

Marine coastal waters have received a great deal of attention most likely due to the public health concerns associated with the contamination of shellfish growing beds and the potential exposure pathway to enteric virus infection risk from coastal recreation, e.g. swimming, water skiing, scuba diving, and surfing (Bosch et al., 2006; Dyble et al., 2008; Gerba, 2006; Griffin et al., 2003; Stewart et al., 2008).

- The European Union regulations concerning the quality of bathing waters, European Directive 76/160/ECC, stipulates monitoring for viruses, with a standard of 0 EVs per 10 liters.
Recent studies are addressing the fate and distribution of human EVs and other human picornaviruses in tropical coastal marine environments in Latin America where research studies had been limited and disposal of untreated wastewater into the coastal ocean is a common practice (Betancourt et al., 2015). Overall, these studies have highlighted several relevant findings related to the occurrence and public health significance of human EVs in the coastal environment: (i) EVs are suitable and valuable indicators of human fecal pollution in coastal waters, although they are not ideal viral indicators for all fecally excreted viruses in all situations and geographic locations; (ii) EV detection by RT-PCR/RT-qPCR is a highly sensitive and easy-to-use tool for rapid assessment of marine water quality and fecal contamination provided that adequate sample process controls are included - from concentration to genome amplification - to accurately detect and quantify EV genomes; (iii) the inclusion of ICC-RT-PCR in studies of human EVs in coastal waters serves as a further processing step for enhancing the sensitivity of the EV detection assay with multiple advantages including the capacity to reveal the circulation of specific EV serotypes and other human picornaviruses (e.g. Aichi virus and Parechovirus) in sewage-polluted coastal waters, i.e. ENVS; (iv) molecular typing methods based on RT-PCR and nucleotide sequencing of portions of the VP1 gene (i.e., direct genotyping identification) can be used to obtain location- 
specific data on enterovirus serotypes in coastal waters, which is of practical value in epidemiological surveillance and in outbreak investigation as previously mentioned; and (v) most frequently EV concentrations in marine waters are not correlated with concentrations of bacterial indicators of sewage pollution as previously documented, although the simultaneous occurrence of EVs and fecal indicator bacteria in water quality monitoring can be used in most geographical settings as a reasonable indication of recent fecal contamination and therefore of chronic pollution problems in coastal waters (Betancourt et al., 2015; Boehm et al., 2003; Connell et al., 2012; Donaldson et al., 2002; Fuhrman et al., 2005; Gersberg et al., 2006; Gregory et al., 2006; Kitajima and Gerba, 2015; Lipp et al., 2001b; Lipp et al., 2001c; Moce-Llivina et al., 2005; Wetz et al., 2004; Wyer et al., 1995).

\subsubsection{Epidemiological evidence for marine recreational disease}

Epidemiological evidence of EV-associated infections transmitted by swimming in contaminated seawater has been limited, most likely due to variability and inefficiency of analytical techniques and lack of epidemiological studies that establish a link between EV illnesses and marine water exposure. Begier et al. (Begier et al., 2008) reported the first outbreak of primarily EV illnesses among travelers to Mexico that likely occurred as a result of swimming in sewage-contaminated seawater. All sea swimming exposures were associated with increased risk of EV infection, and only the time spent on swimming was significantly associated with increased risk of EV infection. QMRAs can be used to evaluate the likelihood that adverse health effects will occur following exposure to coastal recreational waters in which human viruses are present. For these purposes, effective investigations and documentation of EV outbreaks, quantitative data of EVs and thorough consideration of the sources of their infections are necessary, otherwise such assessments will remain difficult to conduct or, when conducted, will be quite uncertain in their outcomes (Parkin et al., 2003). Most commonly, fecal indicator bacteria have been used as predictors of acute gastroenteritis or gastrointestinal illness - the main health outcome - among swimmers at wastewater-impacted recreational beaches and in exploratory quantitative microbial risk assessments (Arnold et al., 2013; Wade et al., 2010). Acute gastroenteritis is a generic term used to refer to gastrointestinal illness involving diarrhea, nausea, or vomiting, which may or may not also be combined with abdominal pain, abdominal cramps, or systemic symptoms, such as fever (Parashar and Glass, 2012; Roy et al., 2006). It is also the common definition given to waterborne diseases (Annon, 1999). However, EVs cause a wide spectrum of acute disease as previously mentioned. Therefore, the use of QMRAs when investigating recreational exposure assessments to enteric viruses must be based on quantitative detection of specific viruses and not on fecal indicator bacteria, as fecal indicator bacteria-based QMRAs frequently underestimate virus occurrence and associated health risks (Symonds and Breibart, 2015).

\subsubsection{Occurrence in shellfish}

EV contamination has been reported in areas routinely impacted by sewage with a frequency of detection of $19 \%$ that can increase up to $45 \%$ in highly contaminated sites (Le Guyader et al., 2000). Another study reported EV detection in shellfish tissue from shellfish collected from six of nine beach $(66 \%)$ sites tested. In this case study, the frequency of detection of EV was higher in shellfish than in water samples from corresponding locations (Connell et al., 2012). EVs have been detected in high quality harvesting areas in Portugal with $35 \%$ of the batches analyzed showing signs of enteroviral contamination, 33\% showing hepatitis A virus contamination, and $37 \%$ showing signs of NoV contamination (Mesquita et al., 2011). Due to bioaccumulation of human enteropathogenic viruses (e.g., EVs and NoVs) by indigenous filter-feeding bivalve mollusks these organisms have been suggested as potential biosentinels of human waste in marine coastal waters (Asahina et al., 2009). No PVs were found in shellfish during ENVS for PV in shellfish in the Netherlands downstream from an accidental discharge of high amounts of virulent poliovirus from a vaccine production facility in Brussels (Duizer, 2015; ECDC, 2014).

Although several studies have demonstrated EV contamination in shellfish harvested from polluted and even relatively clean sites, these viruses have not been directly associated with shellfish or seafood vectored infection (Lees, 2000).

\subsection{Persistence}

The persistence and survival of human enteric viruses, including EVs and other picornaviruses, in the extracellular environment (e.g., water, soil, food, aerosols, and environmental surfaces or fomites), the combination of factors that influence survival (i.e., temperature and seasonal variation, $\mathrm{pH}$, salinity, relative humidity, sunlight irradiation and UV light penetration, wet weather flows, viral aggregation, viral adsorption to suspended solids or surfaces, microbial biome and microbial predation), the risks for transmission of $\mathrm{EV}$ infections through environmental exposures (water, foods, aerosols, and fomites), and prevention strategies to reduce this risk have been extensively documented by peer-reviewed scientific research and reviewed in detail by several authors (Bertrand et al., 2012; Bosch et al., 2006; de Roda Husman et al., 2009; Gerba, 2006, 2007; Gerba et al., 2013; John and Rose, 2005; Rzezutka and Cook, 2004; Vasickova and Kovarcik, 2013; Vasickova et al., 2010; Xagoraraki et al., 2014; Yates and Yates, 1988) EV virions can survive outside the body for months under favorable environmental conditions (Bosch et al., 2006; Dowdle and Birmingham, 1997; Mattle et al., 2011; National Research Council, 2004; Pallansch et al., 2013; Templeton et al., 2004; Templeton et al., 2008; Young and Sharp, 1977). These conditions include neutral $\mathrm{pH}$, moisture, low temperature: $4-10^{\circ} \mathrm{C}$ ), and association with particles in untreated or partly treated waste waters that protects against inactivation by natural or artificial processes, including enzymatic (i.e., proteolytic bacterial enzymes) or UV degradation and chemical disinfection (discussed further in Section 3.2). The 
biophysical properties of picornaviruses such as their smallsize (30 nm), genome type (ssRNA), and non-enveloped capsid structure of the virions are known to play an important role on the mechanisms of virus survival and transport in the environment (Bosch et al., 2006; Fong and Lipp, 2005; Gerba et al., 2013; National Research Council, 2004; Sobsey and Meschke, 2003; Wigginton and Kohn, 2012; Xagoraraki et al., 2014). Processing conditions for picornavirus capsid assembly enable thermal stability (stable at $42^{\circ} \mathrm{C}$ or up to $50^{\circ} \mathrm{C}$ in presence of sulfhydryl reducing agents and magnesium cations) and $\mathrm{pH}$ stability (pH 3 - 9) in the extracellular environment (Gerba, 2007; Hurst and Adcock, 2000; Hurst and Murphy, 1996; National Research Council, 2004; Racaniello, 2013). Capsid protein interaction with genomic RNA genome adds stabilization (Pallansch et al., 2013). Electrostatic and hydrophobic interactions involving functional groups of the viral capsid (i.e., charged amino acids residues) are essential for capsid assembly, capsid stability, and virus particle adsorption to solid surfaces (e.g., suspended solids, sediments and environmental surfaces or fomites) (Mateu, 2011; Michen and Graule, 2010). Binding of serotype 1 polio vaccine strains (Mahoney and Sabin 1) to bacteria or bacterial polysaccharides offers a selective advantage by enhancing capsid stability in the environment (Robinson et al., 2014).

\subsubsection{Persistence in aquatic environments.}

Persistence of EVs in aquatic environments can be inferred from initial concentrations and T90 and T99 inactivation times, the times required to reduce the number of virus by $1 \log _{10}$ and $2 \log _{10}$, respectively. T90 and T99 parameters have been derived from different studies under different experimental conditions (light intensity, type of water, turbidity, and $\mathrm{pH}$ ) and different methods to determine $\mathrm{EV}$ inactivation rates (cell culture versus molecular methods). As a result, wide variations in inactivation times for the same enterovirus or other members within the Picornaviridae family have been reported in different studies. Several examples will be provided.

T90 and T99 times for in situ natural inactivation of laboratory stocks of Echovirus- 6 and CV-B5 were 1.5 and 3.7 days respectively, at $24-25^{\circ} \mathrm{C}$, Salinity $36-37 \%$, $\mathrm{pH}$ $7.7-8.1$, turbidity $0.8-1.8$ nephelometric turbidity units (Moce-Llivina et al., 2005). In seawater, the time required for a reduction of $2 \log _{10}$ titer of poliovirus type 1 ranged between 3 days at $25^{\circ} \mathrm{C}$ and 6 days at $5^{\circ} \mathrm{C}$ (Callahan et al., 1995; Chung and Sobsey, 1993).

The T90 and T99 decay rates for infectivity and viral RNA genome detection of poliovirus strain Lsc- 1 was 2 and 4 days, respectively, in unfiltered natural seawater at $30^{\circ} \mathrm{C}$, while it was 2.2 and 4.4 days, respectively at $22^{\circ} \mathrm{C}$ in unfiltered natural seawater (Wetz et al., 2004). Longer time periods (lower rates of virus inactivation) were documented for filtered seawater and distilled water indicating that much of the virus decay was caused by factors biological in nature (i.e., microbial activity). Little difference was noted in the decay rates of the virus due to temperatures. In a different experiment with the same poliovirus strain comparing sterile and non-sterile marine waters under different environmental conditions (e.g., Temperature 22 $27^{\circ} \mathrm{C}$; Salinity 8 - 35\%; Turbidity $<1-4$ nephelometric turbidity units, polluted versus non-polluted water, sunlight vs darkness), the T90 values in marine waters kept in the dark ranged between 1 and 1.1 days whereas only 0.4 days were required for a $1 \log _{10}$ reduction of the virus in marine waters and the inactivation rate in the polluted canal water was $3 \mathrm{x}$ faster than in non-polluted marine waters with sunlight (Johnson et al., 1997).

PV remained infectious for 90 days at $10^{\circ} \mathrm{C}$ in wastewater and groundwater and persisted for more than a year in mineral water stored at $4^{\circ} \mathrm{C}$ (Biziagos et al., 1988).

Differences in T90 inactivation rates for EVs in fresh water depends on the water temperature: 1 to 1.5 days at $12-20^{\circ} \mathrm{C}\left(\mathrm{O}^{\prime}\right.$ Brien and Newman 1977 as cited in (Carter, 2005)) while inactivation by 6.5 to $7 \log _{10}$ units for CV-B3, Echovirus-7 and PV1 required 8 weeks at $22^{\circ} \mathrm{C}$, and a 4 to 5 $\log _{10}$ inactivation of the same viruses at $4^{\circ} \mathrm{C}$ required 12 weeks (Hurst, 1988a).

\subsubsection{Persistence in groundwater}

Persistence of EVs in groundwater can be inferred from temperature-based inactivation studies (John and Rose, 2005; Schijven and Hassanizadeh, 2000). As above, variations in inactivation times for the same enterovirus or other members within the Picornaviridae family have been reported: The mean inactivation rate of PV was to 0.02 $\log _{10}$ per day (range $0.005-0.05 \log _{10}$ per day ) between 0 and $10^{\circ} \mathrm{C}$ and $0.4 \log _{10}$ per day (range $0.006-1.4 \log _{10}$ per day) at $26-30^{\circ} \mathrm{C}$; the mean inactivation rate for echovirus was $0.1 \log _{10}$ per day (range $0.05-0.2 \log _{10}$ per day) at temperatures between 11 and $15^{\circ} \mathrm{C}$, and $0.2 \log _{10}$ per day- 1 (range 0.06 - $0.6 \log _{10}$ per day) at temperatures between 21 and $25^{\circ} \mathrm{C}$; and the mean inactivation rate for coxsackieviruses was $0.06 \log _{10}$ per day-1 (range $0.002-0.2$ $\log _{10}$ per day) at temperatures between 0 and $20^{\circ} \mathrm{C}$ and 0.1 $\log _{10}$ per day at temperatures between 25 and $30^{\circ} \mathrm{C}$.

\subsubsection{Persistence In biofilms}

Incorporation of enteroviruses into biofilms of drinking water distribution systems and into natural waste water biofilms protects the virus genome from degradation and to a certain extent, prevents inactivation (Skraber et al., 2009) and Vanden Bosschose (cited in (Skraber et al., 2005)). Persistent EVs may be present in biofilm sloughs in water distribution systems, and persistence of EVs in wastewater biofilms may extend the temporal dispersal of viral pollution in water environments after periods of prevalence in wastewaters.

\subsubsection{Persistence In soil}

Table 9 provides the data on inactivation rates of enteroviruses in soils. Poliovirus can survive for at least 12 days in soils at $37^{\circ} \mathrm{C}$ and for months at temperatures at or below $4^{\circ} \mathrm{C}$ when moisture content is above $2.9 \%$, but are 
rapidly eliminated within a few days when moisture content is $\leq 1.2 \%$ (Dowdle et al., 2006). Sensitivities may vary among different isolates of the same virus serotype (for example see Dowdle et al. (2006) for differences between oral poliovirus strains and wild polioviruses).

\section{Table 9. Reported enterovirus inactivation rates in soils}

\begin{tabular}{|c|c|c|c|c|c|}
\hline Virus & $\begin{array}{c}\text { Inactivation Rate } \\
\text { Log10/d }\end{array}$ & $\begin{array}{c}\text { Temperature } \\
\left({ }^{\circ} \mathbf{C}\right)\end{array}$ & Medium & Sand/Silt/Clay \% & pH \\
\hline Echovirus 1 & 0.057 & 25 & Cecil clay & 46/18.9/35.1 & 4.6 \\
\hline Echovirus 1 & 0.057 & 25 & Ponzer muck & $\mathrm{NR}^{\mathrm{a}}$ & 3.6 \\
\hline Echovirus 1 & 0.095 & 25 & Cecil clay & $46 / 18.9 / 35.1$ & 4.6 \\
\hline Echovirus 1 & 0.048 & 25 & Corolla sand & $98.1 / 0.8 / 1.1$ & 8.3 \\
\hline Echovirus 1 & 0.026 & 25 & Kaolinite & $0.5 / 0.5 / 99$ & NR \\
\hline Echovirus 1 & 0.029 to 0.057 & 25 & Bentonite & $0.5 / 0.5 / 99$ & NR \\
\hline Echovirus 1 & 0.032 to 0.048 & 25 & Flushing meadows & $89 / 8 / 3$ & NR \\
\hline Echovirus 1 & 0.036 & 25 & Corolla sand & $98.1 / 0.8 / 1.1$ & 8.3 \\
\hline Echovirus 1 & 0.036 & 25 & Kaolinite & $0.5 / 0.5 / 99$ & NR \\
\hline Echovirus 1 & 0.048 & 25 & Ponzer muck & NR & 3.6 \\
\hline Echovirus 1 V239 & 0.007 & 5 & Rubicon sand & $92 / 4 / 4$ & 7.1 \\
\hline Echovirus 1 V239 & 0.019 to 0.022 & 25 & Pomello sand & $89 / 8 / 3$ & 7.1 \\
\hline Echovirus 1 V239 & 0.026 to 0.027 & 25 & Flushing meadow & $89 / 8 / 3$ & 7.8 \\
\hline Poliovirus 1 & 0.019 & 25 & Pomello sand & $89 / 8 / 3$ & 7.1 \\
\hline Poliovirus 1 & 0.007 & 5 & Rubicon sand & $92 / 4 / 4$ & 7.1 \\
\hline Poliovirus 1 & 0.02 to 0.027 & 25 & $\begin{array}{l}\text { Flushing meadows } \\
\text { sand }\end{array}$ & $89 / 8 / 3$ & 7.8 \\
\hline Poliovirus 1 & 0.016 & 25 & Pomello sand & $89 / 8 / 3$ & 7.1 \\
\hline Poliovirus 1 & 0.009 & 5 & Rubicon sand & $92 / 4 / 4$ & 7.1 \\
\hline Poliovirus 1 & 0.071 & 25 & Ponzer muck & NR & 3.6 \\
\hline Poliovirus 1 & 0.041 & 25 & Corolla sand & $98.1 / 0.8 / 1.1$ & 8.3 \\
\hline Poliovirus 1 & 0.032 & 25 & Flushing meadows & $89 / 8 / 3$ & NR \\
\hline Poliovirus 1 & 0.026 & 25 & Bentonite & $0.5 / 0.5 / 99$ & NR \\
\hline Poliovirus 1 & 0.095 & 25 & Ponzer muck & NR & 3.6 \\
\hline Poliovirus 1 & 0.071 & 25 & Flushing meadows & $89 / 8 / 3$ & NR \\
\hline Poliovirus 1 & 0.032 to 0.036 & 25 & Cecil clay & $46 / 18.9 / 35.1$ & 4.6 \\
\hline Poliovirus 1 & 0.041 & 25 & Kaolinite & $0.5 / 0.5 / 99$ & NR \\
\hline Poliovirus 1 & 0.095 & 25 & Coroll sand & $98.1 / 0.8 / 1.1$ & 8.3 \\
\hline Poliovirus 1 & 0.048 & 25 & Bentonite & $0.5 / 0.5 / 99$ & NR \\
\hline Poliovirus 1 & 0.029 & 25 & Kaolinite & $0.5 / 0.5 / 99$ & NR \\
\hline
\end{tabular}


${ }^{\mathrm{a}}$ No: Not reporte ${ }^{\circ}$

Studies have shown that the extent of virus adsorption differ among the soil types and among the viruses. The rates of inactivation of poliovirus and echovirus vary due to differences between the two viruses in adsorption to soils. Poliovirus adsorbs most extensively by clay soils (cecil clay, bentonite, kaolinite) than echovirus and therefore shows longer persistence in clay soils than echovirus. In general, echovirus reductions in sandy soil columns were lower than those of poliovirus. Moreover, the extent of echovirus reduction in columns was not strongly influenced by soil texture but was greater at the higher temperature of $25^{\circ} \mathrm{C}$. At $5^{\circ} \mathrm{C}$ both viruses show lower inactivation rates than at higher temperatures. The data reported in this table show ranges of inactivation for poliovirus and echovirus in soils when multiple assays were conducted.

Source: (Yates, 2002)

Studies conducted during the early 1980s found that EV persistence in soils was influenced by temperature, soil moisture content, degree of virus adsorption to soil, soil levels of resin-extractable phosphorus, exchangeable aluminum and the pH (Hurst et al., 1980). Table 10 shows the data on sorption behavior of enteroviruses with various types of sorbents. Variations in experimental conditions in the various studies make it difficult to draw general conclusions. Variations in experimental conditions in the various studies make it difficult to draw general conclusions. However, in general, the mechanisms of virus adsorption to solid surfaces depend on the chemical composition of the liquid phase and the nature of the solid surface. Key variables influencing sorption are $\mathrm{pH}$ and ionic strength of the solution, presence of compounds competing for sorption sites, functional groups, and isoelectric points of virus and sorbent. EVs can persist in soils for prolonged periods of time, especially at lower temperatures $\left(4-8^{\circ} \mathrm{C}\right)$ than at higher temperatures $\left(20-37^{\circ} \mathrm{C}\right)$ (Rzezutka and Carducci, 2013; Vasickova and Kovarcik, 2013) and under in anaerobic conditions (Yates, 2002). Depending on the type of virus and sorbent, sorption is dominated by electrostatic interactions, van der Waals forces, hydrophobic effects, and covalent binding to surfaces (Yates, 2002). EV adsorption to clays protect the virions from inactivation by increasing stability of the viral capsid, by adsorption of enzymes and other inactivating substances, and prevention of aggregate formation (Gerba, 2007). 
Table 10. Enterovirus adsorption to soils

\begin{tabular}{|c|c|c|c|c|c|c|c|c|c|}
\hline Virus & $\begin{array}{c}\text { Adsorption } \\
\text { Coefficient (ml/g) }\end{array}$ & Soil & Text & ure & pH & $\begin{array}{c}\text { Surface Area } \\
\left(\mathrm{m}^{2} / \mathrm{g}\right)\end{array}$ & CEC (meq/100g) & $\begin{array}{c}\text { Organic } \\
\text { Matter (\%) }\end{array}$ & Remarks \\
\hline & & $\begin{array}{c}\text { Sand } \\
\text { (\%) }\end{array}$ & $\begin{array}{l}\text { Silt } \\
\text { (\%) }\end{array}$ & $\begin{array}{c}\text { Clay } \\
\text { (\%) }\end{array}$ & & & & & \\
\hline $\begin{array}{l}\text { Coxsackievirus } \\
\text { B3 }\end{array}$ & 32.33 & 59 & 13 & 28 & 8 & 52 & 23 & 1.4 & buffer \\
\hline $\begin{array}{l}\text { Coxsackievirus } \\
\text { B3 }\end{array}$ & 32.33 & 40 & 24 & 36 & 8 & 105 & 30 & 0.78 & buffer \\
\hline $\begin{array}{l}\text { Coxsackievirus } \\
\text { B3 }\end{array}$ & 2.7 & 92 & 4 & 4 & 5.5 & 18 & 5.6 & 0.4 & buffer \\
\hline $\begin{array}{l}\text { Coxsackievirus } \\
\text { B3 }\end{array}$ & 0.54 & 77 & 10 & 13 & 8.2 & 38 & 4.2 & 0.27 & buffer \\
\hline $\begin{array}{l}\text { Coxsackievirus } \\
\text { B3 }\end{array}$ & 4.88 & 13 & 16 & 53 & 4.9 & 15 & 53 & 1.4 & buffer \\
\hline $\begin{array}{l}\text { Coxsackievirus } \\
\text { B3 }\end{array}$ & 11.5 & 26 & 20 & 54 & 7.1 & 203 & 71 & 4.2 & buffer \\
\hline $\begin{array}{l}\text { Coxsackievirus } \\
\text { B3 }\end{array}$ & 249 & 48 & 13 & 39 & 4.5 & 84 & 32 & 0.3 & buffer \\
\hline Echovirus & 0.0309 & 98.1 & 0.8 & 1.1 & 8.3 & $\mathrm{NR}^{\mathrm{a}}$ & NR & NR & $\begin{array}{c}\text { Secondary } \\
\text { effluent } \\
\text { pH } 7\end{array}$ \\
\hline Echovirus & 0.042 & 98.1 & 0.8 & 1.1 & 8.3 & NR & NR & NR & $\begin{array}{c}\text { Primary } \\
\text { effluent } \\
\text { pH } 7\end{array}$ \\
\hline Echovirus 1 & 0.12 & 59 & 13 & 28 & 8 & 52 & 23 & 1.4 & buffer \\
\hline Echovirus 1 & 0.27 & 26 & 20 & 54 & 7.1 & 203 & 71 & 4.2 & buffer \\
\hline Echovirus 1 & 3.55 & 92 & 4 & 4 & 5.5 & 18 & 5.6 & 0.4 & buffer \\
\hline Echovirus 1 & 0.15 & 77 & 10 & 13 & 8.2 & 38 & 4.2 & 0.27 & buffer \\
\hline Echovirus 1 & 332.33 & 48 & 13 & 39 & 4.5 & 84 & 32 & 0.3 & buffer \\
\hline Echovirus 1 & 9 & 13 & 16 & 53 & 4.9 & 15 & 53 & 1.4 & buffer \\
\hline Echovirus 1 & 99 & 46 & 19 & 35 & 4.6 & NR & NR & NR & $\begin{array}{c}\text { Ground } \\
\text { water pH } \\
7\end{array}$ \\
\hline Poliovirus 1 & 99 & 46 & 19 & 35 & 4.6 & NR & NR & NR & $\begin{array}{c}\text { Ground } \\
\text { water } \mathrm{pH} \\
7\end{array}$ \\
\hline Poliovirus 1 & 0.724 & 96.1 & 0.8 & 1.1 & 8.3 & NR & NR & NR & $\begin{array}{l}\text { Primary } \\
\text { effluent } \\
\text { pH } 7\end{array}$ \\
\hline Poliovirus 1 & 99 & 46 & 19 & 35 & 4.6 & NR & NR & NR & $\begin{array}{c}\text { Primary } \\
\text { effluent } \\
\text { pH } 7\end{array}$ \\
\hline Poliovirus 1 & 0.515 & 98.1 & 0.8 & 1.1 & 8.3 & NR & NR & NR & $\begin{array}{c}\text { Secondary } \\
\text { effluent } \\
\text { pH } 7\end{array}$ \\
\hline $\begin{array}{l}\text { Poliovirus } 1 \\
\text { LSc }\end{array}$ & 19 & 26 & 20 & 54 & 7.1 & 203 & 71 & 4.2 & buffer \\
\hline $\begin{array}{l}\text { Poliovirus } 1 \\
\text { LSc }\end{array}$ & 4.58 & 77 & 10 & 13 & 8.2 & 38 & 4.2 & 0.27 & buffer \\
\hline $\begin{array}{l}\text { Poliovirus } 1 \\
\text { LSc }\end{array}$ & 1.27 & 92 & 4 & 4 & 5.5 & 18 & 5.6 & 0.4 & buffer \\
\hline $\begin{array}{l}\text { Poliovirus } 1 \\
\text { LSc }\end{array}$ & 15.67 & 13 & 16 & 53 & 4.9 & 15 & 53 & 1.4 & buffer \\
\hline $\begin{array}{l}\text { Poliovirus } 1 \\
\text { LSc }\end{array}$ & 99 & 59 & 13 & 28 & 8 & 52 & 23 & 1.4 & buffer \\
\hline
\end{tabular}




\begin{tabular}{|c|c|c|c|c|c|c|c|}
\hline Virus & $\begin{array}{c}\text { Adsorption } \\
\text { Coefficient (ml/g) }\end{array}$ & Soil Texture & pH & $\begin{array}{c}\text { Surface Area } \\
\left(\mathrm{m}^{2} / \mathrm{g}\right)\end{array}$ & CEC (meq/100g) & $\begin{array}{c}\text { Organic } \\
\text { Matter (\%) }\end{array}$ & Remarks \\
\hline $\begin{array}{l}\text { Poliovirus } 1 \\
\text { LSc }\end{array}$ & 999 & $13 \quad 39$ & 4.5 & 84 & 32 & 0.3 & buffer \\
\hline
\end{tabular}

${ }^{a}$ NR: Not reported

The adsorption of viruses to soils and other surfaces may prolong or reduce their survival, depending on the properties of the sorbent. However, the mechanisms whereby adsorption to a solid surface prolongs or reduces virus survival have not been elucidated. Several possibilities have been suggested, including interference with the action of virucides, increased stability of the viral protein capsid, prevention of aggregate formation, and adsorption of enzymes and other inactivating substances. $25^{\circ} \mathrm{C}$. Viruses, like poliovirus, are adsorbed relatively efficiently by soils with high clay content and relatively poorly by soils with a high sand content. The latter is also applicable to enteroviruses such as echoviruses and coxsackieviruses. The data presented in this table also indicate that under most test conditions, differences in water quality did not influence virus adsorption efficiency.

Source: (Yates, 2002)

\subsection{Reductions by Sanitation Management}

Factors affecting removal of viruses from wastewater are discussed below. Removal of virus from wastewater is often incomplete resulting in viral pollution of the environment at levels that are still sufficient for viral transmission (Okoh et al., 2010; Rodriguez-Diaz et al., 2009; Theron and Cloete, 2002). In fact, wastewater effluents are often the major source of enteric virus contamination of the environments (Simmons et al., 2011). The review by Stenstrom et al (Stenström et al., 2011) has provided a detailed description of risk of exposure and transmission of enteric pathogens related to various sanitation technologies. Applying reduction values determined for a facility measured in the past to the same type of facility today is not straightforward. On one hand, Improvements in technology and monitoring techniques for measuring inactivation/removal data over time mean extending the lower limits of detection, while on the other hand, inactivation/removal efficiencies may be overestimated for older facilities as equipment deteriorates with age time (Chong et al., 2012).

\subsection{Wastewater Treatment}

The following discussion is mainly limited to reviewing reports that included data on enterovirus inactivation/removal. The majority of the reports also contained data on inactivation/removal of other enteric pathogens such as non-enterovirus enteric viruses, bacteria and parasites. This comparative data, highly relevant when considering the use of indicator organisms to represent behavior of all of the enteric pathogens has not been included.

\subsubsection{Onsite waterless sanitation}

\subsubsection{Passive inactivation by storage of human excreta}

A general consensus is that most, but not all, enteric viruses will be removed from solid excreta by storage of 1.5 - 2 years at $20^{\circ} \mathrm{C}(\mathrm{WHO}, 2006)$. Alkaline treatment at temperatures $>35^{\circ} \mathrm{C}$, sufficient moisture and $\mathrm{pH}>9$ can reduce this time to 6 months. Elevated temperature, rising $\mathrm{pH}$ and ammonium concentrations are the main inactivating agents for urine stored in closed containers, resulting in a $1 \log _{10}$ decrease in rotaviruses and index bacteriophages at $20^{\circ} \mathrm{C}$ within 35 and 71 days, respectively, but almost none at $5^{\circ} \mathrm{C}$ (Stenström et al., 2011). Survival times differ in different natural settings (see Table 12). Inactivation times for fecal bacteria (enteric viruses were not tested) were slower on beach sand adjacent to contaminated seawater (Zhang et al., 2015), while survival timeswere longer for particle-associated poliovirus in seawater than for free poliovirus (Rao et al., 1986).

3.1.1.2 Dry sanitation for small systems or individual households

Dry sanitation includes pit latrines, vault toilets, dry toilets, urine separating toilets, and composting toilets and the information about the survival of human pathogenic viruses during storage, treatment and utilization of composted feces is scarce and scattered over the literature (Guardabassi et al., 2003).

The data suggest that in pit latrines all pathogens are likely to be destroyed after storage of $>$ two years (Stenström et al., 2011). Yet the requirements depending on the temperature only mandate 1 hour up to 2 weeks. Consistent with pit latrines as a source of this viral contamination is the observation that most of the ground water contamination that was associated with pit latrines was reported within 50 meters downstream of the latrines (Tillett, 2013; Verheyen et al., 2009) especially in freshly dug latrines where establishment of biofilm and maximum soil-filtering may take months to establish (Graham and Polizzotto, 2013). Viral contamination of ground water has often been associated with proximity to pit latrines where transport of the virus may occur through ground water flow in the upper part of the soil and/or by surface water runoff (Abbaszadegan et al., 2003; Borchardt et al., 2003; Borchardt et al., 2004; Fout et al., 2003; Graham and Polizzotto, 2013; Keswick et al., 1982; Sagik et al., 1980; Tillett, 2013; Verheyen et al., 2009) (see also Section 2.0). Seasonal contamination of the environment especially surface waters can occur during flooding for pit latrines 
located in flood-prone areas (Stenström et al., 2011). The amount of contamination detected depends on hydrological and soil condition, rainfall including the height of the groundwater table and soil condition, the methods chosen for detection, and the viral target (Graham and Polizzotto, 2013; Rao et al., 1986; Stenström et al., 2011; Tillett, 2013). Enteroviruses were recovered from the walls of the latrine, surface soil, soil at a depth of $10 \mathrm{~cm}$, food preparation area and inside the home, and on toys and dishes (Pickering et al., 2012). Vault toilets are "improved pit latrines" where excreta are sealed off from the environment by containment in closed tanks. The contents of these tanks are periodically removed and transported to wastewater treatment facilities for decontamination. Enteric viruses may undergo degradation and inactivation to varying extents during storage, while binding to organic particles may act to prolong viability. Solids must be removed for treatment to inactivate/remove viruses at waste treatment facilities (see Section 3.1.8) or for composting (this Section below).

Dry toilets do not use flush water to dilute and remove excreta. They conserve water and reduce the cost of preparation of gray water for reuse compared with flush toilets that combine wet and solid waste with the greywater (Magri et al., 2013). Virus inactivation is dependent on the retention time and the $\mathrm{pH}$ and ammonia content during desiccation as demonstrated for bacteriophages MS2 and $\Phi X$ (Magri et al., 2013). Six months storage after last use may be sufficient to reduce pathogens in the solids for all climates, but secondary treatment such as thermophilic composting at $50^{\circ} \mathrm{C}$, longer storage, chemical treatment with urea, and heat is recommended (Rieck et al., 2012). Under low moisture conditions, a 6 to 12 month storage time is required to reduce viruses by up to $4 \log _{10}$ units as opposed to bacteria and some parasites which may be reduced by up to $6 \log _{10}$ (Stenström et al., 2011). While bacteria will be eliminated within 1.5 to 2 years at 4 to $20^{\circ} \mathrm{C}$, some virus may still persist (Stenström et al., 2011). In contrast, Dutch legislation implies that controlled composting (exposure to $55^{\circ} \mathrm{C}$ for two weeks) or controlled sanitation (exposure to $70^{\circ} \mathrm{C}$ for one hour) ensures complete inactivation of all human pathogenic viruses occurring In human feces (Guardabassi et al., 2003).

The urine contains useful nutrients (such as phosphorus, nitrogen, potassium, sulphur and micronutrients). Urine is generally considered to have a much lower pathogen load than solid excreta, but may also contain bacteria or viruses from certain viral infections (Rieck et al., 2012) and/or be contamination by incomplete separation from solid excreta (Stenström et al., 2011). Urine can be infiltrated in soil or be treated by storage in closed containers to eliminate potential pathogens from cross contamination with solid excreta or from certain viral infections (Rieck et al., 2012; Stenström et al., 2011).

Table 11 demonstrates the relationship between type of waterless sanitation mechanism and log reduction of viruses. Elevated temperature, rising $\mathrm{pH}$ and ammonium concentrations were the main inactivating agents for stored urine. As for solid waste, storage time, temperature, $\mathrm{pH}$ and ammonia concentration influenced the inactivation/removal of the pathogens. Rieck et al (Rieck et al., 2012) reported that storage for one month was sufficient for crops that were cooked, whereas six months was required for edible crops that were eaten uncooked while others recommend different inactivation times (Stenström et al., 2011).

Table 11. Recommended inactivation conditions for reducing enteric viruses and virus surrogates in pit latrines and dry toilets to below health risk levels

\begin{tabular}{|c|c|c|c|c|c|c|}
\hline $\begin{array}{l}\text { Matrices } \\
\text { Analyzed }\end{array}$ & Virus & $\begin{array}{c}\log _{10} \\
\text { Reductions }\end{array}$ & $\begin{array}{l}\text { Time } \\
\text { Days }\end{array}$ & $\underset{{ }^{\circ} \mathrm{C}}{\text { Temperature }}$ & $\begin{array}{c}\text { Other } \\
\text { Environmental } \\
\text { Conditions }\end{array}$ & References \\
\hline Double Pit latrine & Enteric viruses & $\begin{array}{l}\text { Partial to } \\
\text { complete }\end{array}$ & $>730$ & 4- 20 & NR & $\begin{array}{c}\text { Stenström et al., } \\
2011\end{array}$ \\
\hline Double Pit latrine & $\begin{array}{l}\text { Bacteriophage } \\
\text { MS2 and phiX }\end{array}$ & 7 & $\begin{array}{l}83 \text { to } \\
125\end{array}$ & $\mathrm{NR}^{\mathrm{a}}$ & Dessication & $\begin{array}{l}\text { Magri et al., } \\
2013\end{array}$ \\
\hline Double Pit latrine & Viruses & 4 & $\begin{array}{l}180 \text { to } \\
275\end{array}$ & NR & Low moisture & $\begin{array}{c}\text { Stenström et al., } \\
2011\end{array}$ \\
\hline $\begin{array}{l}\text { Composting } \\
\text { toilets }^{b}\end{array}$ & NR & 〜Complete & $\begin{array}{c}365 \text { to } \\
730\end{array}$ & Mesophilic & 30:1 carbon:nitrogen & Berger, 2011 \\
\hline $\begin{array}{l}\text { Composting } \\
\text { toilets }^{\mathrm{b}}\end{array}$ & NR & $\sim$ Complete & 14 & 55 & 30:1 carbon:nitrogen & Berger, 2011 \\
\hline $\begin{array}{l}\text { Composting } \\
\text { toilets }^{b}\end{array}$ & NR & $\sim$ Complete & 7 & 60 & 30:1 carbon:nitrogen & Berger, 2011 \\
\hline $\begin{array}{l}\text { Composting } \\
\text { toilets }^{b}\end{array}$ & NR & $\sim$ Complete & 7 to 28 & 50 to 60 & 30:1 carbon:nitrogen & WHO, 2006 \\
\hline
\end{tabular}

${ }^{\mathrm{a} N R}$ : Not Reported; ${ }^{\mathrm{b}} \mathrm{pH} 6.5$ to 7.5 . 
Table 12 shows log reductions of enteric viruses by storage in feces, manure and urine. Factors that affect composting most are (1) the mixture of bacteria, fungi and worms; (2) temperature (including that generated from microbial degradation) and time for composting; (3) $40-70 \%$ moisture, levels most appropriate for the microorganisms and worms; and (4) probably most important, sufficient aeration (McCaustland et al., 1982; Stenström et al., 2011; USEPA, 1999b).

Table 12. Inactivation of human enteric viruses by storage in feces, manure and urine

\begin{tabular}{|c|c|c|c|c|c|}
\hline Virus & $\begin{array}{c}\log _{10} \\
\text { Reductions }\end{array}$ & $\begin{array}{l}\text { Time } \\
\text { (Days) }\end{array}$ & $\begin{array}{c}\text { Temperature } \\
{ }^{\circ} \mathrm{C} \\
\end{array}$ & Other Environmental Conditions & Reference \\
\hline Poliovirus & 1 & 18.7 & 20.8 & $\begin{array}{c}\text { Feces }^{\mathrm{a}} \\
\text { Mixed waste (human/animal) }\end{array}$ & $\begin{array}{c}\text { Deng and } \\
\text { Cliver, } 1992\end{array}$ \\
\hline Poliovirus & 1 & 6.8 & 25 & $\begin{array}{c}\text { Feces }^{\mathrm{a}} \\
\text { Mixed waste (human/animal) }\end{array}$ & $\begin{array}{l}\text { Deng and } \\
\text { Cliver, } 1992\end{array}$ \\
\hline Poliovirus & 1 & 1.3 & 37 & $\begin{array}{c}\text { Feces }^{\mathrm{a}} \\
\text { Mixed waste (human/animal) }\end{array}$ & $\begin{array}{c}\text { Deng and } \\
\text { Cliver, } 1992\end{array}$ \\
\hline Poliovirus & 2 & 5.5 & Ambient & Storage in river water & $\begin{array}{l}\text { Dowdle et } \\
\text { al., } 2006\end{array}$ \\
\hline Poliovirus & 2 & 2.5 & Ambient & Storage in sea water & $\begin{array}{l}\text { Dowdle et } \\
\text { al., } 2006\end{array}$ \\
\hline Poliovirus & $\begin{array}{c}3 \\
4.5 \\
4.5\end{array}$ & 14 & $\begin{array}{c}4 \\
18 \\
25\end{array}$ & Storage in river water ${ }^{b}$ & $\begin{array}{l}\text { Skraber et } \\
\text { al., } 2004\end{array}$ \\
\hline Poliovirus & 1 & 26 & $\mathrm{NR}^{\mathrm{c}}$ & Storage in open sewage canals & $\begin{array}{l}\text { Dowdle et } \\
\text { al., } 2006\end{array}$ \\
\hline Poliovirus & 4 & $\begin{array}{c}83 \text { to } \\
84\end{array}$ & 25 & $\begin{array}{c}\text { Passive storage composting } \\
\text { Feces }\end{array}$ & $\begin{array}{l}\text { Guardabassi } \\
\text { et al., } 2003\end{array}$ \\
\hline Poliovirus & 4 & $\begin{array}{c}20 \text { to } \\
21\end{array}$ & 40 & $\begin{array}{c}\text { Passive storage composting } \\
\text { Feces }\end{array}$ & $\begin{array}{l}\text { Guardabassi } \\
\text { et al., } 2003\end{array}$ \\
\hline $\begin{array}{l}\text { Hepatitis } \\
\text { A Virus }\end{array}$ & 1 to 2 & 100 & Low ambient & Passive storage composting contaminated manure & $\begin{array}{l}\text { Guardabassi } \\
\text { et al., } 2003\end{array}$ \\
\hline $\begin{array}{l}\text { Hepatitis } \\
\text { A Virus }\end{array}$ & 1 to 2 & $\begin{array}{l}625 \text { to } \\
1250\end{array}$ & Low ambient & $\begin{array}{c}\text { Feces } \\
\text { Passive storage composting }\end{array}$ & $\begin{array}{l}\text { Guardabassi } \\
\text { et al., } 2003\end{array}$ \\
\hline $\begin{array}{l}\text { Hepatitis } \\
\text { A virus }\end{array}$ & 4 & 139 & 25 & $\begin{array}{c}\text { Feces } \\
\text { Passive storage composting }\end{array}$ & $\begin{array}{l}\text { Guardabassi } \\
\text { et al., } 2003\end{array}$ \\
\hline $\begin{array}{l}\text { Hepatitis } \\
\text { A Virus }\end{array}$ & 4 & 29 & 40 & $\begin{array}{c}\text { Feces } \\
\text { Passive storage composting }\end{array}$ & $\begin{array}{l}\text { Guardabassi } \\
\text { et al., } 2003\end{array}$ \\
\hline Rotavirus & 1 & 35 & 20 & Urine & $\begin{array}{l}\text { Stenström } \\
\text { et al., } 2011\end{array}$ \\
\hline Rotavirus & 1 & 71 & 20 & Urine & $\begin{array}{l}\text { Stenström } \\
\text { et al., } 2011\end{array}$ \\
\hline
\end{tabular}

${ }^{\mathrm{a}} \mathrm{pH}$ 6.9; ${ }^{\mathrm{b}} \mathrm{pH} 7.7$ to 8.1 ; $^{\mathrm{c}} \mathrm{NR}$ : Not reported.

Composting toilets are dry toilets where solid and liquid excreta are broken down over time under aerobic conditions by microorganisms (bacteria and fungi) and/or redworms or manure worms into a humus-like end product that can be used to recycle nutrients. Virus survival in composted human feces depends not only in the conditions used for composting, but also in the storage conditions and synergistic interactions between them (Dumontet et al., 1999; Guardabassi et al., 2003).

As diagnostic tests evolve and limits for detection drop, inactivation/removal of pathogens to levels below detection becomes more difficult and may require prolonged composting times, elevated temperatures and even some form of secondary treatment at an external site (Berger, 2011; WHO, 2006).

- Conservative estimates for removal of enteric pathogens under mesophilic batch composting conditions may require composting for 1 to 2 years, while only two weeks or one week are required when composting under thermophilic composting 
temperatures of $55^{\circ} \mathrm{C}$ or $60^{\circ} \mathrm{C}$, respectively (Berger, 2011) while the WHO recommends even longer composting times of one month at $55^{\circ} \mathrm{C}$ to $60^{\circ} \mathrm{C}$ with a further 2 - 4 month maturation period (WHO, 2006).

- A much less conservative estimate is that the pathogens can be destroyed by composting for one month, one week, one day, or one hour when the composting is performed at $43^{\circ} \mathrm{C}, 46^{\circ} \mathrm{C}, 50^{\circ} \mathrm{C}$, and $62^{\circ} \mathrm{C}$, respectively.

- Enteric viruses may need shorter times for inactivation compared to enteric pathogens such as helminth eggs.

When deciding which inactivation conditions should be used, the minimum requirements of inactivation should be sufficient to inactivate enteric viral pathogens equivalent to HAV which were shown to remain viable in dried feces stored at $25^{\circ} \mathrm{C}$ and $42 \%$ relative humidity for 30 days (McCaustland et al., 1982). Proper maintenance of composting conditions is important to reduce or eliminate the potential for pathogen transmission to personnel involve in crying out the maintenance which consists mainly of adding bulking agents (biodegradable, carbon rich wood chips, grass clippings, sawdust, chopped straw, etc.) and removing and handling of the finished compost (McCaustland et al., 1982; USEPA, 1999b). Appropriate personal protective equipment (nitrile gloves under rubber gloves, work boots, goggles, disposable polyethylene suits or their equivalent, and face masks more for protection against flies than respiratory protection) should be worn when crying out these tasks (Burton and Dowell, 2011). Risk for infection be EVs and other enteric pathogens that have not yet been inactivated is highest when there is a very short time interval between the last addition of excreta and removal of compost as can occur when there is only a single collection chamber rather than multiple containers whose use can be rotated (Berger, 2011).

\subsubsection{Water-based sanitation - onsite and small systems}

Septic tanks are onsite, relatively small sewage treatment facilities consisting of a holding tank where solids settle and together with non-settleable materials within the scum layer undergo anaerobic degradation and an outlet for the wastewater to flow into draining fields where clarified effluent percolates into the soil. Johkasou are septic tanks with an obligate aerobic treatment process with some versions including urine separation and membrane filtration (Gaulke, 2006). Settlement of solids and hydraulic retention time are the major processes influencing pathogen removal from wastewater in septic tanks (Canter and Knox, 1985). Most viruses are removed in the soil drainage field depending on death rate, flow rate, filtration, adsorption on soil particles, microbial competition and antagonism, moisture, $\mathrm{pH}$, sunlight, and temperature, while $<2 \log _{10}$ are removed during sedimentation (Hagedorn, 1994; Lusk et al., 2014). In both systems, the solids are periodically removed (see Section 3.1.8 on treatment of biosolid waste) and viruses will accumulate in these solids.

Enteric viruses are typically reduced by in the effluent less than $0.3 \log _{10}$ (Stenström et al., 2011; WHO, 2006). Storage and treatment conditions are important resulting in a 17 to 80 day variation in the number of days for $1 \log _{10}$ reduction of PV (Snowdon et al., 1989) (Table 13). Depending on regulations, solid septic waste may be disposed in the environment or preferable receive further treatment in centralized facilities. As in Sections 3.1.1 and 2.0. one of the main health hazards is the ability of viruses to penetrate into groundwater and reach potable water wells (Abbaszadegan et al., 2003; Borchardt et al., 2003; Borchardt et al., 2004; Fout et al., 2003; Keswick et al., 1982; Sagik et al., 1980). Contamination of groundwater with EV and other enteric pathogens from septic tanks depends on: (i) soil properties and the depth of the vadose zone (a subsurface zone of soil or rock containing fluid under pressure that is less than that of the atmosphere) more than on system design; (ii) Soil type and temperature - sandy soils with seasonally high water tables can cause groundwater contamination with enteric pathogens under suboptimal conditions; (iii) soil texture - risks are highest in coarse textured (sand) soils when water tables are shallow (e.g., small vadose zone or saturated soil conditions) and in winter when temperatures are low; and (iv) clay content large reductions in enteric pathogens are possible when the clay content of the drainage field is at least $15 \%$, the vadose zone is at least $1 \mathrm{~m}$ deep, and when the drainage field distribution lines do not become submerged in the groundwater (Butler and Smith, 2002). To achieve a level of safety according to risk assessment and geostatistical investigation by the USEPA, septic tank fields should be located 80 - $325 \mathrm{~m}$ away from abstraction wells, depending on aquifer and source characteristics to allow for natural reduction of up to $11 \log _{10}$ between source and ground water (Butler and Smith, 2002).

Table 13. Poliovirus reductions by septic tanks as water-based sanitation

\begin{tabular}{|c|c|c|c|c|c|}
\hline Virus & $\log _{10}$ Reductions & $\begin{array}{l}\text { Time } \\
\text { Days }\end{array}$ & $\begin{array}{c}\text { Temperature } \\
{ }^{\circ} \mathrm{C} \\
\end{array}$ & Other Environmental Conditions & References \\
\hline $\begin{array}{l}\text { Poliovirus } \\
\text { Type } 1\end{array}$ & 1 & 80 & 5 & $\begin{array}{l}\text { Lab model - septic tank effluent } \\
\text { alone }\end{array}$ & $\begin{array}{l}\text { Snowdon et } \\
\text { al., } 1989\end{array}$ \\
\hline $\begin{array}{l}\text { Poliovirus } \\
\text { Type } 1\end{array}$ & 1 & 19 & $5^{\mathrm{a}}$ & $\begin{array}{l}\text { Lab model - septic tank effluent } \\
\text { mixed with dairy manure slurry }\end{array}$ & $\begin{array}{l}\text { Snowdon et } \\
\text { al., } 1989\end{array}$ \\
\hline $\begin{array}{l}\text { Poliovirus } \\
\text { Type } 1\end{array}$ & 1 & 72 & 15 & $\begin{array}{c}\text { Lab model - septic tank effluent } \\
\text { alone }\end{array}$ & $\begin{array}{l}\text { Snowdon et } \\
\text { al., } 1989\end{array}$ \\
\hline
\end{tabular}




\begin{tabular}{|c|c|c|c|c|c|}
\hline Virus & $\log _{10}$ Reductions & $\begin{array}{l}\text { Time } \\
\text { Days }\end{array}$ & $\begin{array}{c}\text { Temperature } \\
{ }^{\circ} \mathrm{C} \\
\end{array}$ & Other Environmental Conditions & References \\
\hline $\begin{array}{l}\text { Poliovirus } \\
\text { Type } 1\end{array}$ & 1 & 20 & 15 & $\begin{array}{l}\text { Lab model - septic tank effluent } \\
\text { mixed with dairy manure slurry }\end{array}$ & $\begin{array}{l}\text { Snowdon et } \\
\text { al., } 1989\end{array}$ \\
\hline $\begin{array}{l}\text { Poliovirus } \\
\text { Type } 1\end{array}$ & 1 & 19 & 25 & $\begin{array}{c}\text { Lab model - septic tank effluent } \\
\text { alone }\end{array}$ & $\begin{array}{l}\text { Snowdon et } \\
\text { al., } 1989\end{array}$ \\
\hline $\begin{array}{l}\text { Poliovirus } \\
\text { Type } 1\end{array}$ & 1 & 17 & 25 & $\begin{array}{l}\text { Lab model - septic tank effluent } \\
\text { mixed with dairy manure slurry }\end{array}$ & $\begin{array}{l}\text { Snowdon et } \\
\text { al., } 1989\end{array}$ \\
\hline
\end{tabular}

${ }^{a}$ Significantly shorter inactivation times when manure was added were attributed to progressive strong adsorption of virus to manure solids such that the virus was no longer extractable and at least in part, to bacteria and perhaps to the organic acids in the slurry (Snowdon et al., 1989).

\subsubsection{Waste stabilization ponds}

Waste stabilization ponds are used extensively worldwide for wastewater treatment including use as systems supplying reclaimed wastewater for agricultural purposes (see review by Verbyla and Mihelcic (Verbyla and Mihelcic, 2015)). Verbyla and Mihelcic analyzed reports describing 71 different ponds (anaerobic, facultative, maturation, surface aerated ponds, and any of these used in conjunction with other wastewater treatments). They calculated an average $1 \log _{10}$ reduction in enteric virus for every 14.5 to 20.9 days of retention (with up to 54 days for two standard deviations of reported values). The wide variations in physical, chemical, and biological characteristics of the ponds make it difficult to relate inactivation/reduction of viruses directly to fluid retention times. Ponds are frequently integrated with primary and secondary wastewater treatment (see Section 3.1.5). Inactivation/removal of viruses, particles, and particleassociated viruses during these other steps will influence the viral loads reaching and subsequently being processed in the ponds (Symonds et al., 2014).

Climate, temperature, $\mathrm{pH}$ and ammonium concentration, sunlight, interaction of virus with particles and microorganisms, and pond geometry, hydraulic conditions, and retention time are important factors in determining whether, and to what extent, the maximum reported reduction of enteric viruses by $4 \log _{10}$ in waste stabilization ponds (WHO, 2006) can be approached (Stenström et al., 2011; Verbyla and Mihelcic, 2015; WHO, 2015a). For example, Oragui et al (Oragui et al., 1987) reported $3 \log _{10}$ reduction for enteroviruses in a series of anaerobic, facultative and retention ponds with an overall retention time of 21 days at a temperature of $25^{\circ} \mathrm{C}$. The relative contribution of each of the above factors towards inactivation/removal depends on the type of virus and to some extent on the micro flora and fauna communities residing in the ponds (Verbyla and Mihelcic, 2015). Some factors, such as sunlight, may work directly on the virus and/or indirectly by forming chemically reactive intermediates or radicals. Estimated average inactivation times for poliovirus in sludge formed in waste stabilization pools varied from 180 days at $2^{\circ} \mathrm{C}$ to 26 days at $23^{\circ} \mathrm{C}$ (WHO, 2015a). Some ponds also include further UV, ozone, peracetic acid, and/or chlorination steps to remove residual enteric pathogens (See Sections 3.2).

\subsubsection{Wetlands}

Dissolved biodegradable material is removed from wastewater in wetlands by microorganisms (bacteria, fungi, and actinomycetes) in suspension, growing on soils, and growing on aquatic plants. The plants and algae provide oxygen for aerobic degradation, while anaerobic degradation can occur in settled material. Effluents compared to influents have lower BOD and generally lower $\mathrm{pH}$ due to biological activities. Plants also play an active role in taking up nitrogen, phosphorus, and other compounds from the wastewater (Robert A. Gearheart in (USEPA, 1993)). Variation in EV reduction may be high due to wide changes in physical conditions and biological compositions of plants and microorganisms in different wetlands. A combination of elevated water temperature and biological activities in natural wetland water reduced PV1 by 1 to $4 \log _{10}$ (Rachmadi et al., 2016) and EV removal ranged from 2 to $3 \log _{10}$ (Williams et al., 1995). Additional data on removal of EVs in wetlands for wastewater treatment are given in Table 14. Virus persistence (see Section 2.3) is also relevant when considering the minimal time required for removal/inactivation of EVs in wetlands. A viral inactivation step to reduce the load of enteric viral pollutants prior to influx reduces the risk for transmission. However, once EVs enter wetlands, there was significantly more inactivation/removal in the presence of aquatic plants (Gersberg et al., 1987; Karim et al., 2008; Schaub et al., 1980) and aerobic organisms in sandy loams (Hurst, 1988b). 
Table 14. Enterovirus reduction by environment-based systems: lagoons and ponds

\begin{tabular}{|c|c|c|c|c|c|c|}
\hline Matrices Analyzed & Virus & $\begin{array}{c}\log _{10} \\
\text { Reductions }\end{array}$ & $\begin{array}{l}\text { Time } \\
\text { Days }\end{array}$ & $\begin{array}{c}\text { Temperature } \\
{ }^{\circ} \mathrm{C}\end{array}$ & Other Environmental Conditions & References \\
\hline $\begin{array}{l}\text { Anaerobic, } \\
\text { facultative and } \\
\text { retention ponds }\end{array}$ & Enterovirus & 3 & 21 & 25 & $\mathrm{NR}^{\mathrm{a}}$ & $\begin{array}{l}\text { Oragui et } \\
\text { al., } 1987\end{array}$ \\
\hline Lagoons and ponds & $\begin{array}{c}\text { Enteric } \\
\text { viruses and } \\
\text { coliphage }\end{array}$ & 1 & $\begin{array}{l}14.5 \\
\text { to } \\
20.9\end{array}$ & Variable & Review of literature on 71 ponds & $\begin{array}{l}\text { Verbyla and } \\
\text { Mihelcic, } \\
2015\end{array}$ \\
\hline Oxidation pond & Poliovirus & 3 & 70 & 18 to 23 & NR & $\begin{array}{l}\text { Kott et al., } \\
1978\end{array}$ \\
\hline Wetlands & Enterovirus & 2 to 3 & 0.25 & 22 to 27 & $\begin{array}{l}\text { Gravel bed hydroponics constructed } \\
\text { wetlands }\end{array}$ & $\begin{array}{l}\text { Williams et } \\
\text { al., } 1995\end{array}$ \\
\hline $\begin{array}{l}\text { Gravel-based } \\
\text { constructed } \\
\text { wetlands }^{\mathrm{b}}\end{array}$ & Poliovirus & 0.8 to 1.0 & NR & NR & $\begin{array}{l}\text { Presence of plants significantly } \\
\text { increased removal }\end{array}$ & $\begin{array}{l}\text { Karim et } \\
\text { al., } 2008\end{array}$ \\
\hline $\begin{array}{l}\text { Land treatment - } \\
\text { managed aquifer } \\
\text { recharge }\end{array}$ & Enterovirus & 1 to 3.7 & NR & NR & $\begin{array}{l}\text { Recharge of ground water by } \\
\text { filtration through soil }\end{array}$ & $\begin{array}{l}\text { Betancourt } \\
\text { et al., } 2014\end{array}$ \\
\hline
\end{tabular}

${ }^{\mathrm{a}} \mathrm{NR}:$ Not Reported; ${ }^{\mathrm{b}} \mathrm{pH} 6.9$ to 7.9 .

\subsubsection{Aerated lagoons}

Aerated lagoons are large holding basins where wastewater is aerated to facilitate and accelerate biological degradation of BOD. There are two types, one where energy is supplied to keep the suspension from settling and the other where particles in the suspension settle and then are degraded anaerobically. The retention times are usually short ranging from 6 to 18 days. BOD removal varies from 75 to 90 percent depending on dwell times. Efficiency depends on physical factors (type of soil, surface area, depth, wind action, sunlight, temperature, season), chemical factors (organic material, pH, solids, concentration and nature of waste), and biological factors (type of bacteria, type and quantity of algae, activity of organisms, nutrient deficiencies, toxic concentrations) (Annon, 2015a; USEPA, 2000a).

In early studies of serial ponds, Bausum (Bausum et al., 1983) reported between 2 and $3 \log _{10}$ reductions of enteric viruses in different seasons and higher reduction $\left(3 \log _{10}\right)$ in the first pond in each series, presumably to precipitation of particle bound viruses. In another study 1 $\log _{10}$ removal/inactivation of enteric viruses only occurred under warm ambient conditions and to a lesser extent than coliphages that ranged between 2.8 and $3.4 \log _{10}$. (Locas et al., 2010). Removal/inactivation of coliphages in sunlight in summer $\left(3 \log _{10}\right.$ ) was more effective than in winter $\left(1 \log _{10}\right)$ (Fujioka and Yoneyama, 2002).

\subsubsection{Oxidation ditches}

Microorganisms from activated sludge (see Section 3.1.7.4) are added to digest the biosolids from sewage in oxidation ditches. Stirring aids digestion by increasing the amount of dissolved oxygen available to the microorganisms. In an oxidation ditch, only about $15 \%$ of the original BOD ends up as sludge. At the end of each digestion cycle, part of the activated sludge is recycled into the next batch, while the remaining sludge is removed and processed as described in Section 3.1.8.

Viable virus may be concentrated in the sludge byproduct, while less than $1 \log _{10}$ of virus may be removed from the effluent of oxidation ditches (Okoh et al., 2010; Simmons and Xagoraraki, 2011b). Viruses may remain viable for prolonged periods of time, There was no decrease in EV in sludge kept at $5^{\circ} \mathrm{C}$ for 38 and 17 days obtained from an extended aerated ditch or an oxidative ditch, respectively (Berg et al., 1988).

\subsubsection{Wastewater treatment plants (WWTPs)}

Many reports describe $\log _{10}$ reductions between influents and effluents rather than virus concentrations at each stage of treatment. Data representative of both types of reports will be presented in the text and in Table 15.

In treatment plants wastewater undergoes a series of treatment steps before effluents are returned to the environment. The treatment process can be divided into three major sequential stages (Annon, 2015c). In primary treatment, up to $50 \%$ of the suspended particles and up to $20 \%$ of the BOD are removed by mechanical means. This is followed by secondary treatment where microorganisms that decompose organics remaining after primary treatment using aerobic and/or anaerobic metabolic processes remove between $70-90 \%$ of the biological and at least $70 \%$ of the chemical oxygen demand that was 
carried over. Advanced WWTPs can also incorporate a tertiary treatment step to remove more organic material or filtration to remove turbidity and other impurities and can incorporate disinfection steps.

There are many variations available for each of these steps resulting in a plethora of possible combinations and a real difficulty in determining the contribution of each individual component toward reduction/inactivation of enteric viral pathogens. There are also wide variations in populations within catchment areas of WWTPs and in the mix of waters being processed (domestic, domestic mixed with varying amounts of industrial and or agricultural wastewater).

A report by Hewitt et al (Hewitt et al., 2011) comparing ten different WWTP configurations (moving bed biofilm, trickle filter activated sludge with stabilization pond, activated sludge, waste stabilization pond, and waste stabilization pond with wetland), serving different sized catchment areas (population range: $<1100$ to $>1,000,000$ ) with mixed source of wastewater (domestic, domestic plus industrial and/or industrial waste) is illustrative of the difficulty in making simple comparisons. Despite these large differences, they have provided some methods that enabled comparisons independent of the differences. They found that enterovirus profiles and variations of concentrations were generally independent of population size in influents however higher variability was seen for mid and especially small sized populations. They also reported as expected that viable viruses were likely to be isolated from effluents collected before disinfection. This in part reflects the situation where there are a large number of infected individuals in populations, e.g., the populations have a similar epidemiological distribution of viruses, and differs from the situation where there are one or at most a few infected individuals in a population at the initial stage of an emerging viral infection (see discussion in Section 1.4.1 on Eradication and ENVS for PVs.).

Wastewater treatment facilities may be subject to overloads (influx of fluid volumes greater than the maximum volume the WWTP was designed to handle) resulting in larger loading of pathogens into soil, potable, recreational and agricultural surface waters and even groundwater from various stages during processing. An example is excessive rainfall that overwhelms the physical capacity of the WWTPs of older systems where rainwater is not collected separately from sewage, pit latrines (Section 3.1.1), etc. Unusually high pulses of EVs, for example during accidental release of wild neurovirulent poliovirus from a virus production facility (discussed in Section 1.4.1), may result in release of large amounts of virus even if all stages of wastewater treatment function at maximum efficiency. Finally, WWTPs may release viruses when components systems suffer mechanical failure.

\subsubsection{Primary /preliminary treatment}

The primary treatment step is not designed to actively remove/inactivate enteric viral pathogens. Inactivation/removal is passive and dependent on ambient physical and environmental conditions, WWTP component design, flow rates, the amounts of large and micro solids to which enteric pathogens can bind, and retention times (discussed in more detail in other parts of Section 3.0). Enteric viruses content may be reduced in the effluent from primary treatment by up to $1 \log _{10}$ after flocculation (Section 3.1.7.5) but they accumulate in the sediment (Section 3.8) where they must be inactivated before sediment is disposed or used.

\subsubsection{Secondary treatment}

Data on enteric virus removal after secondary treatment is also presented in Table 15. The secondary treatment step is also not designed to actively remove/inactivate enteric viral pathogens. Enteric viruses are passively removed from the effluent with the smaller particles to which they are adsorbed. By "removed" we mean that they are accumulated in the sludge which itself must be periodically removed and processed to reduce biological pollutants (see Section 3.1.8). The 1972 US Federal Water Pollution Control Act that mandated secondary treatment of municipal sewage in the USA has ensured that there is plenty of sludge that must be processed (Rao et al., 1986). In steps involving recirculation of activated sludge to seed the microorganisms for biodegradation, viral concentrations may paradoxically increase in various compartments (Rao et al., 1986) (see Sections 2.2.1, 3.1.7.4, and 3.1.7.5). Pathogenic viruses are present in effluents from secondary treatment (Rao et al., 1986) and in the sludge byproduct of the process. 
Table 15. Poliovirus reduction by wastewater treatment plants (WWTPs)

\begin{tabular}{|c|c|c|c|c|c|}
\hline Treatment & Virus & $\begin{array}{c}\log 10 \\
\text { Reductions }\end{array}$ & Temperature & $\begin{array}{c}\text { Other Environmental } \\
\text { Conditions }\end{array}$ & Reference \\
\hline $\begin{array}{l}\text { Secondary } \\
\text { treatment }\end{array}$ & Enterovirus & 0.7 to 2.1 & $\mathrm{NR}^{\mathrm{a}}$ & $\begin{array}{l}\text { Primary settlement/ } \\
\text { activated sludge }\end{array}$ & $\begin{array}{l}\text { Lodder and de } \\
\text { Roda Husman, } \\
\quad 2005\end{array}$ \\
\hline $\begin{array}{l}\text { Secondary } \\
\text { treatment }\end{array}$ & Poliovirus & 1 to 2 & Ambient & Removal fine particles & $\begin{array}{l}\text { Dowdle et al., } \\
\quad 2006\end{array}$ \\
\hline $\begin{array}{l}\text { Secondary } \\
\text { treatment }\end{array}$ & $\begin{array}{l}\text { F specific RNA } \\
\text { bacteriophage }\end{array}$ & 2.1 & Ambient & $\begin{array}{l}\text { Screening and grit } \\
\text { removal / activated sludge }\end{array}$ & $\underset{2012}{\text { Flannery et al., }}$ \\
\hline Sedimentation & $\begin{array}{l}\text { Viruses base line } \\
\text { removal }^{\mathrm{b}}\end{array}$ & 0 & NR & Simple ${ }^{C}$ & WHO, 2011 \\
\hline $\begin{array}{l}\text { Filtration } \\
\text { (Granular media) }\end{array}$ & $\begin{array}{l}\text { Viruses base line } \\
\text { removal }\end{array}$ & 0.5 to 1 & NR & $\begin{array}{l}\text { Rapid (RG) } \\
\text { slow sand (SS) }\end{array}$ & WHO, 2011 \\
\hline $\begin{array}{l}\text { Secondary and } \\
\text { tertiary treatment }\end{array}$ & Enterovirus & $\geq 3.2$ & NR & $\begin{array}{c}\text { Activated sludge/Filtration } \\
\text { in sand filter/UV/Chlorine } \\
\text { disinfection }\end{array}$ & $\begin{array}{l}\text { Costan-Longares } \\
\text { et al. } 2008\end{array}$ \\
\hline $\begin{array}{l}\text { Secondary and } \\
\text { tertiary treatment }\end{array}$ & Enterovirus & $\geq 1.9$ & NR & $\begin{array}{l}\text { Activated sludge/settling } \\
\text { pond/oxidation pond/ } \\
\text { constructed wetland }\end{array}$ & $\begin{array}{l}\text { Costan-Longares } \\
\text { et al. } 2008\end{array}$ \\
\hline $\begin{array}{l}\text { Secondary and } \\
\text { tertiary treatment }\end{array}$ & Enterovirus & $\geq 4.0$ & NR & $\begin{array}{c}\text { Activated sludge/coagulation- } \\
\text { flocculation/Filtration in a } \\
\text { multilayer filter/UV/Chlorine } \\
\text { disinfection } 0.3 \mathrm{ppm}\end{array}$ & $\begin{array}{l}\text { Costan-Longares } \\
\text { et al. } 2008\end{array}$ \\
\hline $\begin{array}{l}\text { Secondary and } \\
\text { tertiary treatment }\end{array}$ & Enterovirus & $\geq 4.2$ & NR & $\begin{array}{l}\text { Activated sludge/Coagulation- } \\
\text { flocculation/Decantation/ } \\
\text { Filtration in sand filter/UV/ } \\
\text { Chlorine disinfection }\end{array}$ & $\begin{array}{l}\text { Costan-Longares } \\
\text { et al. } 2008\end{array}$ \\
\hline $\begin{array}{l}\text { Membrane } \\
\text { bioreactors }\end{array}$ & Enterovirus & 3.6 & NR & $\begin{array}{c}\text { Primary settling/Membrane } \\
\text { bioreactors }\end{array}$ & $\underset{2011}{\text { Simmons et al., }}$ \\
\hline
\end{tabular}

${ }^{a}$ NR: Not reported; ${ }^{b}$ Baseline Removals are those typically expected in actual field practice when done by relatively unskilled persons who apply the treatment to raw waters of average and varying quality and where there are minimum facilities or supporting instruments to optimize treatment conditions and practices. This is different from Maximum Removals which are those possible when treatment is optimized by skilled operators who are supported with instrumentation and other tools to maintain the highest level of performance in waters of predictable and unchanging quality (e.g. a test water seeded with known concentrations of specific microbes)" (WHO, 2011); "Simple Sedimentation refers to the physical settling of large particles and large sedimentable microbes to which virus may have been bound in the absence of any additional factors or treatments that enhance this physical settling process. Sedimentation varies with storage time and the concentration of particulates in the water.

Secondary treatments that incorporate a filtration step (i.e., tertiary treatment) remove more fine particles that in turn reduces effluent virus content by 1 to $2.4 \log _{10}$ (Dowdle et al., 2006). A cautionary note: low levels of enteroviruses detected in influent in many studies may result in an overestimation of the efficiency of secondary treatment (Qiu et al., 2015). Secondary treatment may provide substantial but not complete removal of enteroviruses. A protective stabilizing effect has been observed when poliovirus adsorbs to the high amounts of silts and suspended solids associated with wastewaters (Smith et al., 1978).

\subsubsection{Filtration and trickling fllters}

Table 16 shows the effect of combined wastewater treatment processes that include tricking filters for removal of enteroviruses from wastewaters. Log removal for each treatment step are given in this table. 
Table 16. Enterovirus reductions by wastewater treatment

\begin{tabular}{|c|c|c|c|c|c|}
\hline Area & $\begin{array}{l}\text { Virus Type } \\
\text { (Unit of } \\
\text { Measurement) }\end{array}$ & $\begin{array}{c}\text { Average or Range } \\
\log _{10} \\
\text { Reductions }\end{array}$ & $\begin{array}{l}\text { Number of } \\
\text { Samples } \\
\text { (Facilities) }\end{array}$ & Description of Treatment Train & Reference \\
\hline \multirow{5}{*}{$\begin{array}{l}\text { Canada } \\
\text { (Alberta) }\end{array}$} & \multirow{5}{*}{$\begin{array}{l}\text { Enteroviruses } \\
\text { (GC qPCR) }\end{array}$} & $2.55 \pm 1.28$ & $16(1)$ & $\begin{array}{l}\text { Primary sedimentation plus } \\
\text { activated sludge }\end{array}$ & \multirow{5}{*}{$\begin{array}{l}\text { Qiu et al., } \\
\quad 2015\end{array}$} \\
\hline & & $0.58 \pm 0.96$ & $16(1)$ & $\begin{array}{l}\text { Activated sludge followed by UV } \\
\text { disinfection }\end{array}$ & \\
\hline & & $2.06 \pm 1.06$ & $16(1)$ & $\begin{array}{l}\text { Activated sludge plus } \\
\text { ultrafiltration }\end{array}$ & \\
\hline & & $2.81 \pm 1.06$ & $16(1)$ & $\begin{array}{l}\text { Primary sedimentation/Activated } \\
\text { sludge/UV disinfection }\end{array}$ & \\
\hline & & $4.61 \pm 1.12$ & $16(1)$ & $\begin{array}{l}\text { Primary sedimentation/activated } \\
\text { sludge/ultrafiltration }\end{array}$ & \\
\hline Italy & $\begin{array}{l}\text { Enterovirus } \\
\text { (GC } \text { qPCR }^{2}\end{array}$ & $0.18\left(\mathrm{NR}^{\mathrm{b}}\right.$ to 1.5$)$ & $250(5)$ & $\begin{array}{l}\text { Grid separation, primary } \\
\text { sedimentation, biological } \\
\text { treatment by activated sludge and } \\
\text { final disinfection with chlorine. }\end{array}$ & $\begin{array}{l}\text { La Rosa et } \\
\text { al., } 2010\end{array}$ \\
\hline \multirow{2}{*}{$\begin{array}{l}\text { New } \\
\text { Zealand }\end{array}$} & $\begin{array}{l}\text { Culturable enteric } \\
\text { viruses } \\
\text { (MPN cell culture) }\end{array}$ & 1.37 to 2.82 & \multirow[t]{2}{*}{$30(10)$} & \multirow{2}{*}{$\begin{array}{l}\text { Moving bed biofilm reactor or } \\
\text { activated sludge before UV } \\
\text { disinfection }\end{array}$} & \multirow[t]{2}{*}{$\begin{array}{l}\text { Hewitt et } \\
\text { al., } 2011\end{array}$} \\
\hline & $\begin{array}{l}\text { Enterovirus } \\
\text { (GC qPCR) }\end{array}$ & 1.39 to 5.13 & & & \\
\hline \multirow{2}{*}{$\begin{array}{l}\text { Spain } \\
\text { (Mallorca) }\end{array}$} & & 0.7 & $13(1)$ & Lagooning & \multirow{2}{*}{$\begin{array}{l}\text { Gomila et } \\
\text { al., } 2008\end{array}$} \\
\hline & & 0.5 & $13(1)$ & UV disinfection & \\
\hline \multirow{6}{*}{ USA } & \multirow{6}{*}{$\begin{array}{l}\text { Culturable enteric } \\
\text { viruses } \\
\text { (MPN cell culture) }\end{array}$} & $\begin{array}{c}1.89 \pm 1.09 \\
(0.86 \text { to } 3.23)\end{array}$ & $5(1)$ & $\begin{array}{c}\text { Grit removal followed by activated } \\
\text { sludge. Filter type: Cloth. Filter } \\
\text { media Fabric. Chlorine } \\
\text { disinfection }\end{array}$ & \multirow{6}{*}{$\begin{array}{l}\text { Rose et al., } \\
2004\end{array}$} \\
\hline & & $\begin{array}{c}3.04 \pm 0.57 \\
(>3.43 \text { to }>4)\end{array}$ & $5(1)$ & $\begin{array}{l}\text { Pre-chlorination, Grit removal } \\
\text { followed by activated sludge. } \\
\text { Filter type: traveling bridge. } \\
\text { Filter media: sand. Chlorine } \\
\text { disinfection }\end{array}$ & \\
\hline & & $\begin{array}{l}4.27 \pm 0.55 \\
(3.6 \text { to } 4.81)\end{array}$ & $5(1)$ & $\begin{array}{l}\text { Grit removal (primary clarifier) } \\
\text { followed by flocculation with } \\
\text { cationic polyelectrolyte and } \\
\text { activated sludge. Filter type: } \\
\text { monomedium. Filter media: } \\
\text { anthracite }(1.2 \mathrm{~m}) \text {. Chlorine } \\
\text { disinfection }\end{array}$ & \\
\hline & & $\begin{array}{c}3.25 \pm 0.37 \\
(2.86 \text { to } 3.59)\end{array}$ & $5(1)$ & $\begin{array}{l}\text { Grit removal followed by activated } \\
\text { sludge. Filter type: dual media. } \\
\text { Filter media: anthracite }(0.8 \mathrm{~m}) \\
\text { sand }(0.25 \mathrm{~m}) \text {. Chlorine } \\
\text { disinfection }\end{array}$ & \\
\hline & & $\begin{array}{c}2.66 \pm 0.47 \\
(>2.26 \text { to }>3.41)\end{array}$ & $5(1)$ & $\begin{array}{l}\text { Grit removal; equalization basin } \\
\text { followed by nitrification. Filter } \\
\text { type: continuously backwashed } \\
\text { upflow filter. Filter media: sand } \\
(1.2 \mathrm{~m}) \text { UV disinfection (medium } \\
\text { pressure) }\end{array}$ & \\
\hline & & $\begin{array}{c}4.04 \pm 0.49 \\
(3.53 \text { to } 4.54)\end{array}$ & $5(1)$ & $\begin{array}{l}\text { Grit removal followed by } \\
\text { biological nutrient removal. Alum } \\
\text { added to secondary clarifier. } \\
\text { Filter type: dual media. Filter } \\
\text { media: anthracite }(0.6 \mathrm{~m}) \text { sand } \\
(1.2 \mathrm{~m}) \text {. Chlorine disinfection }\end{array}$ & \\
\hline
\end{tabular}




\begin{tabular}{lccc}
\hline Area & $\begin{array}{c}\text { Virus Type } \\
\text { (Unit of } \\
\text { Measurement) }\end{array}$ & $\begin{array}{c}\text { Average or Range } \\
\log _{10} \\
\text { Reductions }\end{array}$ & $\begin{array}{c}\text { Number of } \\
\text { Samples } \\
\text { (Facilities) }\end{array}$
\end{tabular}

USA vilturable enteric
viruses
(MPN cell culture)

$2.41 \pm 0.56$

(1.2 to 3.2$)$

$11(11)$

Enterovirus

(GC qPCR)

3.6 (2.9 to 4.3$)$

$2.9(2.0$ to 3.7$)$

USA

Culturable enteric
viruses
(MPN cell culture)

(1.9 to 5.0$)$
Preliminary, primary, and secondary (activated-sludge) treatment, as well as phosphorus Sedmak et removal, and disinfection using al., 2005 chlorine

Primary and secondary treatment membrane bioreactor

Primary and secondary treatment activated sludge

Primary and secondary treatment and UV disinfection

Simmons et al., 2011

Primary and secondary treatment and chlorine disinfection

${ }^{\mathrm{a}} \mathrm{GC}$ : Gene copies; ${ }^{\mathrm{b}} \mathrm{NR}$ : Not reported; ${ }^{\mathrm{c}} \mathrm{PFU}$ : Plaque forming units.

\subsubsection{Activated sludge}

Conventional activated sludge (CAS) secondary processing usually involves biological degradation after seeding pre-settled sewage from primary processing with microorganisms present in processed sludge. While viruses are removed by wastewater treatment, the concentration may increase in the activated sludge. Harwood et al (Harwood et al., 2005) reported an average 3 $\log _{10}$ reduction of EVs after CAS treatment among six WWTPs in the US. Viable EVs were isolated from $73 \%$ of the secondary treatment samples, and $31 \%$ of the tertiary disinfected effluent and $100 \%$ of the influent samples.

Sedmack et al (Sedmak et al., 2005) reported isolation of EVs in only $62 \%$ of the effluent samples and $99.9 \%$ of the influent samples from a conventional WWTP in Milwaukee, WI, USA, with minimal and maximal concentration reductions of 1.2 and $3.2 \log _{10}$ MPN/L of EVs during a nineyear study. The Milwaukee WWTP consisted of preliminary, primary, and activated-sludge secondary treatment, as well as phosphorus removal, and disinfection using chlorine. In Canada, a $2.55 \pm 1.28 \log _{10}$ of EV was removed by activated sludge secondary treatment, (Qiu et al., 2015).

La Rosa et al. (2010) reported low rates $\left(0.19 \log _{10}\right)$ for removal of enterovirus nucleic acids in the effluent from five Italian conventional activated sludge wastewater treatment plants that included grid separation, primary sedimentation, secondary biological treatment and final disinfection with chlorine. $96 \%$ of the intake samples and $86 \%$ of the effluents samples were enterovirus RNA-positive and many of the enterovirus nucleic acid-positive effluents were shown to contain low levels of culturable EVs. Hewitt et al. (2011) reported slight reductions of culturable EVs in WWTPs of different size compared with a $2 \log _{10}$ reduction of viral nucleic acids by molecular assay for moving bed biofilm reactors (MBBR) and conventional activated sludge (CAS) plants serving large populations and conventional plants that served small populations. Flannery et al.
(Flannery et al., 2012) reported a $2.1 \log _{10}$ reduction in $\mathrm{F}$ specific RNA bacteriophage in a conventional coupled primary (screening and grit removal) and secondary (activated sludge including primary settlement, aeration, and final settlement) WWTP.

\subsubsection{Membrane bioreactors}

Membrane bioreactors (MBRs) are a wastewater treatment technology in which membranes are submerged in the activated sludge tank to separate out solids. In theory viruses should not penetrate the membranes, but as the size of membranes increase, so do the chances for imperfections that would allow virus to penetrate the membrane barrier.

MBR processing was more efficient in microbial removal/inactivation than CAS reactors (Zhang and Farahbakhsh, 2007). A much higher 4.1 - $6.8 \log _{10}$ (average 5.1] decrease in EVs between influent and effluent waters was reported for a full scale MBR system when virus was measured by quantitative RT-PCR (Simmons et al., 2011) compared to CAS. This study also illustrated the importance of viral attachment to biosolids. When particles in the influent to the membrane were allowed to settle, the settled solids attached EVs removing $2.5 \log _{10}$ of the starting amount.

MBRs using UV for tertiary disinfection removed enterovirus more efficiently than CAS reactors using chlorine for disinfection, while chlorine treatment had little additional inactivation effect on enterovirus concentrations (Table 17) (Francy et al., 2012). Tertiary treatment in CAS reactors added a $0.5 \log 10$ removal of EVs to the total reduction from secondary treatment (Ottoson et al., 2006b). The reduction in culturable EVs was slight compared to a $2 \log 10$ reduction by molecular assay for moving bed biofilm reactors and CAS plants serving large populations and CAS plants serving small populations (Hewitt et al., 2011). As discussed above, factors including isoelectric points, hydrophobicity, temperature, $\mathrm{pH}$ and hydraulic retention 
times account for wide variations in virus removal. Ottoson et al. (2006a) compared CAS, MBR and upflow anaerobic sludge blankets (UASB) reactors run in parallel at the same pilot plant in Sweden and reported a 1.7, 1.8 and 0.5 $\log _{10}$ reduction in EVs, respectively. Of significance was their finding that $36 \%$ of the effluent samples from the CAS reactor contained enteroviral genomes, a similar number for the MBR line and even higher for the USAB line.

Table 17. Enterovirus reduction by tertiary treatment

\begin{tabular}{|c|c|c|c|c|}
\hline Treatment & $\begin{array}{l}\text { Virus } \\
\text { Type }\end{array}$ & $\begin{array}{l}\log _{10} \\
\text { Reductions }\end{array}$ & Other Environmental Conditions & Reference \\
\hline $\begin{array}{l}\text { Membrane } \\
\text { bioreactors } \\
(\mathrm{MBR})^{\mathrm{a}}\end{array}$ & Enterovirus & $\begin{array}{l}2.2 \text { to } 4.7 \\
1.1 \text { to } 3.7\end{array}$ & $\begin{array}{l}\text { MBR (full scale) secondary conventional } \\
\text { MBR (full scale) + UV secondary convent. + UV }\end{array}$ & $\begin{array}{l}\text { Francy et al., } \\
\quad 2012\end{array}$ \\
\hline $\begin{array}{l}\text { Membrane } \\
\text { bioreactors }\end{array}$ & Enterovirus & 5.1 & MBR (full scale) & $\begin{array}{l}\text { Simmons et al., } \\
2011\end{array}$ \\
\hline $\begin{array}{l}\text { Membrane } \\
\text { bioreactors }^{\mathrm{a}}\end{array}$ & $\begin{array}{l}\text { Enterovirus live } \\
\text { Enterovirus } \\
\text { genomes }\end{array}$ & $\begin{array}{l}<1 \\
\sim 2\end{array}$ & MBR (full scale) medium and large & $\begin{array}{l}\text { Hewitt et al., } \\
\quad 2011\end{array}$ \\
\hline Membrane filtration & $\begin{array}{l}\text { Viruses base line } \\
\text { removal }^{\mathrm{b}}\end{array}$ & $\begin{array}{l}0 \\
3 \\
3 \\
3\end{array}$ & $\begin{array}{c}\text { Micro (MF), } \\
\text { Ultra (UF), } \\
\text { Nano (NF), } \\
\text { Reverse osmosis (RO) }\end{array}$ & WHO, 2011 \\
\hline Membrane filtration & $\begin{array}{l}\text { Viruses base line } \\
\text { removal }\end{array}$ & 0 & Fiber and fabric & WHO, 2011 \\
\hline $\begin{array}{l}\text { Membrane } \\
\text { bioreactor }\end{array}$ & Enterovirus & 1.8 & $\begin{array}{l}\text { MBR: } 30 \mathrm{~mm} \text { drum filter MBR with a submerged } \\
\text { microfilter, membrane module }(0.4 \mathrm{~mm})\end{array}$ & $\begin{array}{l}\text { Ottoson et al., } \\
2006 a\end{array}$ \\
\hline Porous membranes & $\begin{array}{l}\text { Viruses base line } \\
\text { removal }\end{array}$ & $\mathrm{NR}^{\mathrm{c}}$ & Porous ceramic and carbon block filtration & WHO, 2011 \\
\hline $\begin{array}{l}\text { Tertiary treatment } \\
\text { post secondary }\end{array}$ & Enterovirus & 2 & & $\begin{array}{l}\text { Dowdle et al., } \\
\quad 2006\end{array}$ \\
\hline $\begin{array}{l}\text { Enhanced }^{\mathrm{d}} \\
\text { coagulation with } \\
\mathrm{FeCl}_{3}\end{array}$ & $\begin{array}{c}\text { Coxsackie virus } \\
\text { B6, } \\
\text { Echovirus 11, } \\
\text { Poliovirus }\end{array}$ & 1.8 to 3 & $\begin{array}{l}\text { Coagulant dose of } 40 \mathrm{mg} / \mathrm{L} \mathrm{FeCl}_{3} \text { and a pH below } \\
6.5\end{array}$ & $\begin{array}{l}\text { Mayer et al., } \\
2008\end{array}$ \\
\hline
\end{tabular}

${ }^{a}$ Run at ambient temperatures; ${ }^{b}$ Baseline Removals are those typically expected in actual field practice when done by relatively unskilled persons who apply the treatment to raw waters of average and varying quality and where there are minimum facilities or supporting instruments to optimize treatment conditions and practices. This is different from Maximum Removals which are those possible when treatment is optimized by skilled operators who are supported with instrumentation and other tools to maintain the highest level of performance in waters of predictable and unchanging quality (e.g. a test water seeded with known concentrations of specific microbes)" (WHO, 2011); 'NR:Not Reported; "pH of $6.5,20^{\circ} \mathrm{C}$ at 51 minutes contact time.

The biological and biochemical interactions that occur during membrane bioreactor processing and the physical and hydrodynamic processes of MBRs are very complex (see the review by Zuthi et al. (2012) on modeling these processes in order to design and maintain efficient MBRs). While many of the bioprocesses resemble those that occur in conventional activated sludge (CAS) plants during steady state processing, they are influenced by physical and hydrodynamic parameters specifically associated with MBRs. Most notably are problems associated very long sludge retention times compared with conventional activated sludge reactors (Section 3.1.7.4). Longer retention times allow greater buildup of soluble microbial products, extracellular polymeric substances and higher concentrations of suspended solids that increase viscosity, alter dynamic microbiological equilibriums, alter the oxygen supply available for biological degradation processes, reduce membrane permeability, increase membrane fouling, affect transmembrane pressure and flux, and may contribute to a greater tendency for foaming and higher energy costs.

The complexity produces an apparent paradox relating to removal/inactivation of EVs. On one hand, there is a significant decrease in the amount of enterovirus between the influent the effluent of MBR WWTPs. On the other hand, during eight months of observation of the secondary 
processing stage, the concentrations of enterovirus virus influent to the membrane, e.g., samples taken after the point of addition of returned sludge, were $1.6 \log _{10}$ higher ( $p$-value $<0.05)$ compared with the concentration in primary influent (5.2 $\left.\log _{10}\right)$ and effluent concentrations (Simmons et al., 2011). This increases the difficulties in processing sludge for reuse or disposal (see Section A.8.). Research pertaining to membranes and improvements in membrane performance for MBRs is reviewed annually in Water Environment Research (for example, see Pellegrin (Pellegrin et al., 2011).

Williams (2003) reported that the effectiveness of micro and ultra filtration membrane reverse osmosis for exclusion of biological contaminants varied widely (from $0-3 \log _{10}$ ) depended on the characteristics of the organic contaminant (polarity, size, charge, etc.), physiochemical properties of the membrane, and the reverse osmosis operating conditions (feed $\mathrm{pH}$, operating pressure, etc.). William's review did not refer to use of reverse osmosis to exclude biological contaminants. Howeverin theory, pathogens that are larger in size than the pore size of the membrane should be prevented from passing through the membrane (exclusion based on size). In practice, there is a pore size distribution throughout the filter membrane in addition to imperfections in the membrane or the support system for the membrane that allow a proportion of virus to pass through (Antony et al., 2012).

\subsubsection{Anaerobic /anoxic digestion and biogas}

Poliovirus inactivation of $3 \log _{10}$ within 2 hours under thermophilic anaerobic sludge digestion was reported at temperatures ranging between $51^{\circ} \mathrm{C}$ to $56^{\circ} \mathrm{C}$ (Popat et al., 2010).

There are many different treatment configurations for anaerobic/anoxic digestion and biogas formation from biosolids produced during treatment of wastewater and new technologies chemical cell destruction, micro-sludge, increased digestion of biomass and biogas production by using $\mathrm{NaOH}$ and high-pressure disruptors to break up bacterial cells are emerging (USEPA, 2006). Ultrasonic cell destruction using acoustic waves instead of $\mathrm{NaOH}$, broke up cellular material in the biosolids reducing anaerobic oxidation times, and increased collectible biogas availability for energy production. Electrocoagulation using an electric current to introduce aluminum ions to suspended biosolids, increased particle aggregation until aggregates precipitated, while gas bubbles floated the precipitated aggregates to the surface where they were removed along with $>1 \log _{10}$ coliform. Yet most of these techniques have not been evaluated for EV reductions.

Mass reduction by thermal hydrolysis reduces biomass by dewatering by $0.07-0.9 \log _{10}$, and when followed by oxidation at $160^{\circ} \mathrm{C}$ and 100 psi of pressure and then anaerobic digestion, destroyed pathogens and broke cells reaching high levels of volatile solid destruction and biogas production. Three phase anaerobic digestion (fatty acid digestion; anaerobic thermophilic gas digestion) followed by digestion at temperatures $>35^{\circ} \mathrm{C}$ improved pathogen destruction (Willis and Schafer, 2006), increased biogas production and produced Class A biosolids (defined in Section 3.1.8). Laboratory scale anaerobic digestion with low levels of ozone ( $0.06 \mathrm{~g}$ of ozone per $\mathrm{gm}$ of dissolved solids) increased average digestion of biosolids by $0.5 \log _{10}$ and increased biogas production by $0.2 \log _{10}$ over conventional anaerobic digesters.

Critical factors affecting subsequent process operation performance included conditions and inoculum during start-up of anaerobic digesters and subsequent temperature fluctuations in reactors running between 46 to $53^{\circ} \mathrm{C}$ (a range too high for mesophilic microorganisms and below an optimal $55^{\circ} \mathrm{C}$ for hemophilic organisms (De la Rubia et al., 2013). In upflow anaerobic sludge blanket (UASB) reactors startup may take 2 to 8 months (Chong et al., 2012). Energy recovered from the biogas produced by anaerobic processing is a useful byproduct but is not sufficient by itself to justify anaerobic processing for energy recovery (Kumar, 2011). Combining a mesophilic anaerobic and a thermophilic aerobic processor increased methane production by 24 -fold when the feed sludge and recirculated sludge received thermal alkaline pretreated together (Cho et al., 2013).

\subsubsection{Biosolids}

One of the byproducts of wastewater treatment is the accumulation of sludge or biosolids precipitated during primary and secondary treatment that must be disposed. Table 18 shows reductions of enterovirus in processed activated sludge. 
Table 18. Enterovirus reduction by biosolid treatments

\begin{tabular}{|c|c|c|c|c|c|c|}
\hline Treatment & $\begin{array}{l}\text { Virus } \\
\text { Type }\end{array}$ & $\begin{array}{c}\log _{10} \\
\text { Reductions }\end{array}$ & $\begin{array}{l}\text { Time } \\
\text { Days }\end{array}$ & $\begin{array}{l}\text { Temperature } \\
{ }^{\circ} \mathrm{C} \\
\end{array}$ & $\begin{array}{c}\text { Other Environmental } \\
\text { Conditions }\end{array}$ & Reference \\
\hline $\begin{array}{l}\text { Activated } \\
\text { sludge }\end{array}$ & $\begin{array}{l}\text { Poliovirus in } \\
\text { soil }\end{array}$ & 1 & $\begin{array}{c}\text { Few days } \\
<1 \mathrm{hr} \\
12 \\
180 \\
1.5 \\
20\end{array}$ & $\begin{array}{c}\mathrm{NR}^{\mathrm{a}} \\
\text { Ambient } \\
37 \\
4 \\
\text { Summer } \\
\text { Winter }\end{array}$ & $\begin{array}{c}\text { Moisture }<2.9 \% \\
\text { Dry air stream } \\
\text { Moisture }>2.9 \% \\
\text { Moisture }>2.9 \% \\
\text { Moist } \\
\text { Moist }\end{array}$ & $\begin{array}{l}\text { Dowdle et } \\
\text { al., } 2006\end{array}$ \\
\hline $\begin{array}{l}\text { Biosolids } \\
\text { treatment } \\
\text { (review of } \\
\text { literature) }\end{array}$ & Enteroviruses & $\begin{array}{l}3.6 \\
3.5 \\
1.3\end{array}$ & NR & NR & $\begin{array}{l}\mathrm{COM}^{\mathrm{b}} \\
\text { TPAD }^{\mathrm{c}} \\
\text { MAD }^{\mathrm{d}}\end{array}$ & $\begin{array}{l}\text { Viau et al., } \\
2011\end{array}$ \\
\hline $\begin{array}{l}\text { Biosolids } \\
\text { treatment }\end{array}$ & Enteroviruses & 2 & NR & NR & $\begin{array}{c}\text { In } 3 \text { WWTPs where } \\
\text { sludge treated by MAD } \\
\text { or dewatering }\end{array}$ & $\begin{array}{c}\text { Simmons and } \\
\text { Xagoraraki, } \\
2011 \mathrm{~b}\end{array}$ \\
\hline $\begin{array}{l}\text { Biosolids } \\
\text { treatment } \\
\text { (33\% activated } \\
\text { sludge }+67 \% \\
\text { raw sludge })\end{array}$ & Enteroviruses & 1 to 3 & 20 days & $\begin{array}{l}\sim 35 \\
\sim 49\end{array}$ & $\begin{array}{l}\text { Mesophillic } \\
\text { Thermophilic }\end{array}$ & $\begin{array}{c}\text { Berg and } \\
\text { Berman, } \\
1980\end{array}$ \\
\hline $\begin{array}{l}\text { Conventional } \\
\text { Activated } \\
\text { sludge }\end{array}$ & Enteroviruses & 1.7 & NR & NR & $\begin{array}{l}\text { CAS }^{\mathrm{e}} \text { : Pre-sedimentation, } \\
\text { activated sludge with } \\
\text { biological nitrogen } \\
\text { removal, pre- } \\
\text { denitrification and } \\
\text { chemical precipitation }\end{array}$ & $\begin{array}{l}\text { Ottoson et } \\
\text { al., } 2006\end{array}$ \\
\hline $\begin{array}{l}\text { Conventional } \\
\text { Activated } \\
\text { sludge }\end{array}$ & Poliovirus & 2.5 & NR & NR & Labscale simulation & $\begin{array}{l}\text { Wen et al., } \\
2009\end{array}$ \\
\hline $\begin{array}{l}\text { Upflow } \\
\text { anaerobic } \\
\text { sludge } \\
\text { blanket }\end{array}$ & Enteroviruses & 0.5 & NR & NR & $\begin{array}{l}\text { UASB: Presedimentation, } \\
\text { two UASB reactors in } \\
\text { series, chemical } \\
\text { precipitation and a final } 20 \\
\text { mm drum filter }\end{array}$ & $\begin{array}{l}\text { Ottoson et } \\
\text { al., } 2006\end{array}$ \\
\hline
\end{tabular}

aNR:Not Reported; ${ }^{b}$ COM: Compost; ${ }^{c}$ TPAD: Temperature-phased anaerobic digestion; dMAD: Mesophilic anaerobic digestion; ${ }^{\mathrm{e} C A S}$ : Conventional activated sludge.

Simmons et al. (2011) reported on accumulation of EVs in the sludge itself for three WWTPs with the following primary, secondary and tertiary configurations (1) (MBR) / Mesophilic anaerobic digestion (MAD) /UV; (2) activated sludge /dewatering/chlorination; and (3) rotating biological contactors /MAD/chlorination. The initial influent virus concentration, 4.1 (MPN)/100L (equivalent to $100 \mathrm{~kg}$ ), was concentrated $2 \times 10^{5}$-fold to yield an average of 1.1 to 3.2 (MPN)/gm in the biosolids.

There was an average $4.2 \log _{10}$ (range 1.9 to $5.0 \log _{10}$ ) reduction in infectious virus in sludge after treatment in a study of five WWTPs (Simmons and Xagoraraki, 2011b). Wong et al. (2010) and Monpoeho et al. (2001) reported an average of $4 \log _{10} \mathrm{MPN} / \mathrm{gm}$ in class B sludge after dewatering (four WWTPs) or MAD (thirteen WWTPs). Differences in recovery levels after dewatering and some of the variation in the number of enterovirus positive samples between the two reports may have been due to differences in plant location and virological tests used. Song et al reported better results in terms of reduction of volatile solids and equivalent methane production when anaerobic digestion was separated into two stages involving thermophilic then mesophilic digestion than either process alone, although removal of coliform bacteria was similar for both configurations (Song et al., 2004). An additional number of researchers reported
$<1 \log _{10}$ reductions for EVs between raw and processed biosolids (reviewed in Sidhu and Toze, 2009).

Joo et al. (2015) reviewed over 500 recent publications with the aim of extracting information on sustainable approaches for minimizing biosolids production and maximizing reuse options. They reviewed thermal, chemical, electromagnetic, ultrasonic, microwave, mechanical as well as integrated combinations of these pretreatment methods (composting, vermicomposting, aeration, recovery of nutrients especially phosphorus and nitrogen by use of struvite, or calcium phosphate for precipitation, mixed thickening and high elutriation of sludge), electrodialytic process, cross-flow microfiltration, and a hybrid process of low pressure wet oxidation and nanofiltration) for reducing biosolids production by making organic material in biosolids more available for biodegradation, for reduction of hazardous substances, and for extracting nutrients to enhance and expand reuse options. A combined alkaline and ultrasonic pretreatment for cell disintegration was most effective balancing chemical pretreatment with energy consumption and in reducing biosolids volume by producing $20 \%$ more solubilization than either process alone. Three main systems for composting included aerated static piles, 
enclosed systems and turned windrow systems (Kumar, 2011). Composting with a mixture of bacteria and fungi can be performed on un-separated waste or on waste from which indigestible materials have first been removed with compost quality dependent on the characteristics of the waste and degradation achieved (Kumar, 2011). An alternative, vermicomposting, is land surface intensive and takes longer (Kumar, 2011). Conditions including moisture, $\mathrm{pH}$, temperature $\mathrm{C}: \mathrm{N}$ ratios and microorganism composition (described above for composting toilets, Section 3.1.1) are important for composting of sludge. The USEPA 2006 report (USEPA, 2006) updated in 2013 (USEPA, 2013) reviewed the pros and cons of emerging technologies for different processing stages for treating biosolids including viruses in the USA. Research remains to be done to determine actual viral reduction/inactivation efficiencies. Stages included biosolids thickening, conditioning, stabilization, dewatering, thermal conversion and drying and the processes were categorized as embryonic (bench scale, full scale outside of US) or innovative (tested at full scale in $<25$ locations in USA implemented since 2001, and/or available overseas with some use in USA). Established technologies (used in more than 25 sites in the USA) were excluded from the report.

There are two classes of sludge depending on its intended land application and whether biosolids are pathogen-free (Class A) or only significantly reduced (Class B) (USEPA, 1994). Land application " is the spreading, spraying, injection, or incorporation of sewage sludge, including a material derived from sewage sludge (e.g., compost and pelletized sewage sludge), onto or below the surface of the land to take advantage of the soil enhancing qualities of the sewage sludge". There are many possible WWTP system component configurations that can be assembled to degrade sludge using mesophilic and/or thermophilic, aerobic or anaerobic degradation (for examples see Speece et al (Speece et al., 2006)). Use of anaerobic degradation has lagged behind aerobic degradation (Speece et al., 2006). Important factors leading to increased efficiency of anerobic processes were close microbial proximity to the sludge at mesophilic or thermophilic ranges especially at the start of degradation; availability of inorganic nutrients to reduce volatile fatty acids, and the reactor configuration (Speece et al., 2006). Virus survival in composted human feces depends not only in the conditions used for composting, but also in the storage conditions (Dumontet et al., 1999). For example, viruses can survive the composting process when certain zones of the heap are not exposed or exposed for too short times to the temperatures required for viral inactivation. Average concentrations and reductions of a variety of enteric pathogens in biosolids by composting (COM) and temperature-phased anaerobic digestion (TPAD) for Class A and mesophilic anaerobic digestion (MAD) for Class $B$ biosolids as well as the annual log probability of viral infections associated with land applications and aerosols were examined in detailed reviews by Viau et al. (Viau et al., 2011; Viau and Peccia, 2009). Values for viability and molecular-based determinations were compared. The mean $\log _{10} \pm \mathrm{SD} /$ dried gram in USA and European Union of enterovirus and fecal coliform concentrations in stabilized dried biosolids (number of samples used for average in
USA, and EU)] were $0.4 \pm 0.69,1.7 \pm 1.11,(8,3)$ after COM; $0.2 \pm 0.25$, none analyzed, $(2,0)$ after TPAD; and 0.9 \pm 0.69 , $4.15+0.5,(7,5)$ after MAD processing. The $\log _{10}$ reductions for EVs compared with fecal coliform reduction for COM, TPAD and MAD processing were approximately $3.6 \pm 1.1$ vs $5.6 \pm 0.8 ; 2.8$ vs $3.5 \pm 1.0$; and $1.3 \pm 0.4$ vs $1.6 \pm 0.5$, respectively. Berg and Berman (Berg and Berman, 1980) reported recovery of more EVs from mixtures of one-third activated sludge and two-thirds raw primary sludge digested under mesophilic than hemophilic conditions with an average dwell time of 20 days in digesters fed intermittently on a daily basis (min-max influx 380 to 11,600 plaque forming units (PFU)/100ml; after mesophilic digestion 30 to $410 \mathrm{PFU} / 100 \mathrm{ml}$, approximately a 1 $\log _{10}$ reduction; while after hemophilic digestion $<4$ to 5 PFU/100ml a reduction of 2 to $3 \log _{10}$; compare to $6 \log _{10}$ for fecal coliform bacteria).

Mesophilic anaerobic degradation is the most common method for generating Class B biosolids in the US (Wong et al., 2010). Land and agricultural use of class B sludge has been regulated by the US EPA to reduce pathogen transmission "by allowing time for natural processes to further reduce pathogen levels". Our awareness of the potential health risks from new and emerging enteric pathogens, our ability to test for them, and the increasingly lower limits of detection and quantitation since the time this legislation was formulated has increased exponentially and many of the consequences and lessons from this expanded knowledge have been highlighted in this and other chapters of this book. The major health risk associated with land use of processed activated sludge still appears to be airborne exposure although accidental ingestion also poses a risk, however the list of potential pathogens and conditions necessary for their removal/inactivation have led many state governments in the US to adapt more stringent rules for land use (Viau et al., 2011). More information on pathogen and indicator content in biosolids and risks of infection from ingestion and inhalation have been can be found in the review by Viau et al. (2011).

Viau et al. (2011) also report a growing trend to convert Class B to Class A sludge to reduce the amount of pathogens returned to the environment by adding composting, dewatering, or adding both hemophilic and mesophilic treatment steps. However, even US EPA standard Class A sludge with $<10^{3}$ colony forming units (CFU) bacteria/ dry gram were not enteric pathogen-free and presented a health risk to humans in increasing order through contaminated food ingestion, contaminated groundwater ingestion, aerosol inhalation and accidental direct ingestion....and that is only for the limited number of enteric pathogens that were tested and reported in the literature.

Sludge containing enteric viruses accumulates in lagoons of WWTPs using this process (USEPA, 2002a, $2002 b)$. Virus accumulation is higher in cold climates because of reduced microbial degradation ,but can also be higher during summer because of a shortage of dissolved oxygen (USEPA, 2002a). 


\subsubsection{Land treatment}

Land treatment of municipal wastewater involves a downwards flow along a grade to remove organics and suspended solids by biological oxidation, sedimentation and filtration through the soil (USEPA, 1981; USEPA, 1991). There are three main options: slow flow rate, rapid infiltration and overland flow, with an upper range for remaining fecal coliform of $<10,<200$, and $<2,000$ per 100 $\mathrm{ml}$, respectfully. Vegetation and microorganisms participate in pathogen removal in slow flow treatment, water percolates through permeable soil to ground water in rapid infiltration, while in overland flow, the slope is covered by grass growing in relatively impermeable soil or sub-soil. Enteric virus removal, primarily through adsorption, is best in slow flow rate systems (USEPA, 1981). In rapid flow systems removal efficiency depends on initial concentration, hydraulic loading rate, type of soil, and distance traveled through the soil. When influx viral loads are high, virus can flow off into surface water or can enter the ground water especially if soil permeability is high (USEPA, 1981). (See Section 2.3 on enteric virus survival in soil and surface waters.) When water is applied using sprinklers, virus may also be present on plant surfaces, so crops that are eaten raw should not be used and there should be a sufficient time delay between last application and grazing (usually measured in weeks). The water quality of overland flow is equivalent to that after secondary treatment without disinfection (removal of $<1.5 \log _{10}$ ). Aerosols may spread viable enteric viruses up to 100 meters, especially when sprinklers are used. Rainwater facilitates sub-soil transport (Duboise et al., 1976). Managed aquifer recharge (MAR) systems improve water quality using natural filtration of surface water, storm water, or reclaimed water through soil to recharge ground water.

In MAR systems, virus concentrations have been shown to drop below detection when groundwater residence times exceeded 14 days (equivalent to a 1 to $5 \log _{10}$ reduction depending on virus type) and there was a 1.8 to $>3.7$ $\log _{10}$ reduction in enterovirus genomes (Betancourt et al., 2014). In another study (Sprenger et al., 2014) of an MAR virus was no longer detectable after 50 meters of infiltration and 119 days of underground passage. Microorganisms present in the ground water enhance inactivation/removal of virus (Gordon and Toze, 2003).

\subsection{Disinfection}

Final reductions/inactivation of residual biologically viable pathogens often requires an additional tertiary inactivation step using disinfectants such as chlorine, ozone, paracetic acid or UV radiation (Jacangelo and Trussell, 2002; Mezzanotte et al., 2007; Nocker and Gerba, 2010; Okoh et al., 2010; Rossi et al., 2007).

Enterovirus reduction/inactivation studies measure the amount of viable virus or physical components of the virus in effluent compared with that in influent wastewater at WWTPs using viruses "naturally" present in sewage or after spiking the influent with known amounts of virus. It is important to keep in mind that inactivation of spiked virus may not be equivalent to that for the same virus naturally present in sewage (Payment et al., 1985a; Tree et al., 2003) due to differences in the way the virus is presented during the different disinfection processes. Moreover, inactivation and the contact time required for inactivation vary for different disinfectants and different pathogens (Jacangelo and Trussell, 2002) making it difficult to generalize or compare studies since even different EVs have different inherent resistance to disinfectants (Payment et al., 1985a). Stability of the disinfectant may also be inversely related to its effectiveness, although this may be compensated for by prolonged persistence (Akin et al., 1982). Finally, the effect of multiple inactivation steps such as UV with chlorination may be synergistic (indicator bacteria (Wang et al., 2012); poliovirus with chlorine and copper or silver ions (Yahya et al., 1992).

Disinfectants, mechanisms of action, and factors influencing the efficiency of inactivation are reviewed in depth in Morato et al. (Morato et al., 2003) and Nocker and Gerba (Nocker and Gerba, 2010). Chlorine, chlorine compounds and UV may be less effective against enteric viruses than against bacteria used as indicator organisms (Blatchley et al., 2007; Theron and Cloete, 2002). Inactivation or disinfection refers to the rendering the pathogen nonviable while removal refers to the physical separation or exclusion of the pathogen (see discussion on membranes and ultrafiltration in Sections 1.4.2, 3.1.7 and 3.2.4).

Initial inactivation is often considered to be a first order chemical reaction dependent on the type of disinfection and the ratios of the disinfectant and the microorganism (Akin et al., 1982). Suspended solids to which viruses adsorb usually negatively affect the efficiency of disinfection and digestion (Fong and Lipp, 2005; Schijven and Hassanizadeh, 2010; Templeton et al., 2008) as may virus aggregation (Schijven and Hassanizadeh, 2010), although under some conditions binding to suspended particles may enhances disinfection (see review by Templeton et al., 2008). All chemical disinfection processes produce disinfection byproducts (DBPs) (Annon, 2015c; Blatchley et al., 2007; Doederer et al., 2014; Jacangelo and Trussell, 2002; Verma et al., 2014; WHO, 2011), however the risk of illness and death from pathogens outweighs the risk from exposure to DBPs (WHO, 2011).

\subsubsection{Chlorine}

Chlorine disinfection in sewage suggest that particlebound viruses are extremely important see review by Tempelton (Templeton et al., 2008). Inactivation of poliovirus present in sewage was much less efficient than when the same amount of unbound virus was added as a spike to the sewage (Tree et al., 2003). $\mathrm{Cl}_{2}$ concentrations of 4 - $10 \mathrm{mg} / \mathrm{L}$ for 2 hours were able to inactivate $4 \log _{10}$ of seeded virus but released virus could be detected in receiving waters even after chlorination (Blatchley et al., 2007). In a comparison of six WWTPs, Rose et al. (2004) reported approximately a $2 \log _{10}$ removal of enteric viruses by biological treatments and another 0.3 to $1 \log _{10}$ by filtration with pre-chlorinated shallow sand filters 
correlating with the highest levels of enteric virus removal most likely due to inactivation by the chlorine. Enteric viruses were not detected in effluents from two of the WWTPs that used either pre-chlorinated sand filters or UV after reduction of nutrients (minimal ammonia available to form chloramines).

Concentration, $\mathrm{pH}$, and contact time are the factors most influential in disinfection by chlorination using chlorine gas, sodium hypochlorite solution, calcium hypochlorite, chloramine dioxide and chloramines (Akin et al., 1982; Annon, 2003; Engelbrecht et al., 1980). Inactivation times varied 44 fold among six different poliovirus and non-poliovirus serotypes at the same $\mathrm{pH}$ and between 5-fold to 192-fold when comparing inactivation at pH 6.0 and at pH 10.0 (Akin et al., 1982; Engelbrecht et al., 1980).

Higher concentrations of chlorine (>1000 mg per min per liter) are needed for wastewater that is reused than for wastewater that is simply disposed (40 to $80 \mathrm{mg}$ per min per liter) (Blatchley et al., 2007). Inactivation is less effective when organic particles interact with free and combine chlorine species (Okoh et al., 2010). Excessive use of chlorine is now avoided to reduce the risk for formation of DBPs (Verma et al., 2014). Chlorine and chlorine compounds are less effective against enteric viruses than against bacteria (Rose et al., 2004; Theron and Cloete, 2002) (see discussion of appropriate indicator organisms ). However amounts of chlorine must be used that are sufficient for disinfection of enteric viruses despite DBP formation, since the risk of illness and death from pathogens outweighs the risk from exposure to DBPs (WHO, 2011).

Little data are found on other chlorine based oxidants and their use in wastewater. Jin et al. (2013) has reported that the virucidal concentration of chlorine dioxide on Hand Foot and Mouth Disease Enterovirus 71, (Section 1.0, an emerging enterovirus pathogen) was higher at $\mathrm{pH} 8.2$ than at 5.6 and 7.2 and as expected higher at $36^{\circ} \mathrm{C}$ than at $4^{\circ} \mathrm{C}$.

\subsubsection{Ultraviolet and microwave inactivation}

Virus inactivation by UV is dependent on interaction between high-energy photons and nucleic acids within viral particles that form pyrimidine dimers, other photoproducts, tertiary structural changes, and at high doses $(>1,000 \mathrm{~mW}$ - s/cm ${ }^{2}$ ) may also affect the capsid protein and generate RNA-protein linkages (Cutler and Zimmerman, 2011; Hijnen et al., 2006; Kurosaki et al., 2003; Nuanualsuwan and Cliver, 2003b; Okoh et al., 2010). UV inactivation appears to be effective against all pathogenic organisms although susceptibility of different EVs varied (Hijnen et al., 2006)). Specifically, $3 \log _{10}$ reductions of echovirus 1 , echovirus 11, CV-B3, CV-B5, poliovirus 1, and human adenovirus type 2 were achieved by doses of 25, 20.5, 24.5, 27,23 , and $119 \mathrm{~mW} / \mathrm{cm}^{2}$, respectively. Inactivation occurs with first order kinetics except at very low (little or no inactivation) or high energy levels (tailing off effect) (Hijnen et al., 2006; Nuanualsuwan and Cliver, 2003b). Suspended particles and dissolved UV adsorbing organic and inorganic chemicals decrease the efficiency of inactivation of free virus (Hijnen et al., 2006; Templeton et al., 2004; Templeton et al., 2007). The affect on UV inactivation of particle-bound viruses has been reviewed by Templeton (Templeton et al., 2008).

In contrast to chlorination, large amounts of DBPs are not formed (Ngwenya et al., 2013) and overdose is not possible (Cutler and Zimmerman, 2011). Inactivation of enteric viruses with UV appears more efficient than with chlorine compounds (Blatchley et al., 2007; Hijnen et al., 2006). A study comparing five different treatment configurations (Simmons and Xagoraraki, 2011b) found that those using UV removed/inactivated $2 \log _{10}$ more enterovirus on average than those with chlorine although the decontamination step itself with chlorine inactivated $0.6 \log _{10}$ more enterovirus than the UV step.

See Mudhoo and Shrma (Mudhoo and Sharma, 2011) for a review on the use of microwave technology for disinfection, which may be related to heat generation.

\subsubsection{Ozone}

Ozone $\left(\mathrm{O}_{3}\right)$, one of the strongest oxidants and disinfectant can be generated on-site at water treatment facilities using high voltage treatment of dry oxygen or air. Ozone inactivates by direct oxidation/destruction, of structural components (cell walls, viral capsids), chemical interaction by-products of ozone decomposition, and direct damage to nucleic acids, with dose, mixing, and contact time determining the effectiveness of the inactivation (Roy et al., 1981; USEPA, 1999a).

In sewage, the degree of virus inactivation $\left(>5 \log _{10}\right.$ ) was rapid and biphasic with inactivation dependent on ozone concentration and the amount of organic matter in the effluent (Katzenelson and Biedermann, 1976; Katzenelson et al., 1979). pH during inactivation did not appear to play a significant role even though EVs tend to clump when pH is below 6.0 (Katzenelson et al., 1979).

\subsubsection{Nanotechnology}

Nanoparticles (1-100 nm) are an emerging method for decontamination of wastewater (see reviews by Theron et al., 2008, Qu et al., 2013, and Ngwenya et al., 2013). Nanoparticles have large surface areas per unit mas, short inter-particle diffusion distances, size and shape dependent catalytic properties, pore size and secondary structures that can be manipulated, and they can be coupled to different chemical groups to change or enhance targeting and inactivation of enteroviruses in pretreatment, in slurry reactors or absorbers, and for tertiary and post-tertiary processing (Qu et al., 2013; Theron et al., 2008).

Among the most promising nanomaterials with antimicrobial properties are metallic and metal-oxide nanoparticles, as well as $\mathrm{TiO}_{2}$ photocatalysts (Theron et al., 2008). Photocatylitic nanoparticles can be used in combination with UV and may be an alternative to chlorinebased disinfection (Theron et al., 2008). Recyclability, 
fouling, reduction of fouling by antimicrobial nanomaterials such as nano-Ag and carbon nanotubes, and safety are areas of research that will determine our ability to incorporate nanotechnology into sustainable wastewater treatment.

\section{Appendix A. Environmental Surveillance in Support of Poliovirus Eradication}

Testing of sewage samples and other waste waters for human pathogenic viruses (also known as sewage or environmental surveillance (ENVS)) may reveal significant information about the epidemiological characteristics of multiple enteric viral infections in the population (e.g. natural circulation and changes in circulation of viruses, potential global spread, transmission pathways of circulating virus types) which is valuable for planning and implementing public health responses and interventions (see discussion on ENVS in polio eradication vaccine section) . Sewage surveillance is especially useful in urban settings with limited clinical surveillance. This strategy has been applied around the world to assess the prevalence of EVs (poliovirus and nonpolio EVs) and other picornaviruses circulating in the communities, with important implications toward an understanding of temporal, seasonal, and geographical patterns of disease occurrence, i.e., sporadic, endemic, or epidemic viral circulation, including emergence and reemergence of viral infections in the population (Betancourt et al., 2010; Hovi et al., 2007; Hovi et al., 2012; Khetsuriani et al., 2010; Lodder and de Roda Husman, 2005; Palacios and Oberste, 2005; Rodriguez-Diaz et al., 2009; Sedmak et al., 2003; Shulman et al., 2000; Shulman et al., 2012; Apostol et al., 2012; Harvala et al., 2014; Ibrahim et al., 2014; Li et al., 2014; Richter et al., 2011; Tao et al., 2012; Wang et al., 2014; Yang et al., 2012). The monitoring of sewage waters can also be used as an early warning system for the release, introduction or re-introduction of pathogenic viruses (e.g. poliovirus) from an intentional, natural, or accidental biological contamination (ECDC, 2014; Shulman et al., 2012; Sinclair et al., 2008).

ENVS for poliovirus, which involves testing of sewage and other waste waters for polioviruses, has been widely used to assess the elimination of wild poliovirus (WPV) circulation in a given human population and to demonstrate the successful interruption of PV transmission as part of the WHO Global Poliovirus Eradication Initiative, GPEI (Deshpande et al., 2003; El Bassioni et al., 2003; Hovi et al., 2007; Hovi et al., 2012; Hovi et al., 2001; Matsuura et al., 2000; Shulman et al., 2014b; Avan der Avoort et al., 1995; WHO, 2013a). This strategy is also useful for monitoring the circulation of genetically divergent vaccine-derived polioviruses (VDPVs) and for assessing population immunity of populations vaccinated with inactivated polioviruses (IPVs) (Battistone et al., 2014; Dedepsidis et al., 2007; Hovi et al., 2013; Hovi et al., 2012; Nakamura et al., 2015). The advantage is that environmental surveillance can detect poliovirus circulation in populations in the absence of clinical cases of paralysis since the virus is excreted into sewage during asymptomatic infections as well as symptomatic infections. Standard procedures identifying viruses and especially poliovirus in wastewater have not yet been adopted. However, the US Environmental Protection Agency (USEPA) Manual of Methods for Virology (Berg et al., 1984) and WHO Laboratory Manuals for Environmental Surveillance (WHO, 2015a) have been updated to contain state-of-the-art procedures that have undergone extensive testing. One of the main goals has been and continues to be optimization of sample collection and processing. Moreover while results from environmental surveillance are usually qualitative, they can be semi quantitative as well (Hovi et al., 2001; Lodder et al., 2012; Manor et al., 2014).

Environmental surveillance is sometimes considered as supplementary to human surveillance by health organizations. In contrast to AFP surveillance, standardized methods for environmental surveillance are developed by WHO (WHO, 2015a).

OPV strains are present in sewage in countries where OPV is part of the vaccination program making it much more difficult to screen sewage for the presence of vaccinederived viruses and wild viruses in mixtures containing much higher amounts of vaccine strains. Additional difficulties in detecting polio by environmental surveillance arise from the fact that shedding may depend in part on immune status and competence of the infected human host and shedding may be intermittent (Dowdle et al., 2006). Molecular assays offer one of the best ways to distinguish and even easily quantitate the amount of non-polio vaccine viruses in these mixtures (Hindiyeh et al., 2014; Kilpatrick et al., 2011; Kilpatrick et al., 1998; Kilpatrick et al., 2009).

The following 6 steps are essential for implementing a successful poliovirus environmental surveillance program (Hovi et al., 2012; Shulman et al., 2012): (i) Identify the target population for the surveillance The optimal size of the population in the catchment area should be between 100,000 and 300,000 , and sites should be selected for ease of access and lack of contaminants that can inhibit laboratory molecular and viability studies.; (ii) Ensure the necessary resources and expertise are in place for collection transportation analysis, storage and decontamination.; (iii) Design a practical sampling plan that includes the type of site (sewage or other), the type of sample (grab (semiquantitative) vs trap (not quantitative), the logistics needed for sampling (all lab and non lab needs including storage and transportation of the sample to the diagnostic lab), the duration and frequency of sampling (repeated sampling over extended time improves sensitivity and makes interpretation of negative findings more reliable), and clear lines for communication); (iv) WHO certified sampling processing facilities with appropriately trained personnel, standard sampling protocols, quality controls, data management systems, established turn-around-times for virological testing, results and reporting and appropriate safety standards. SOPs should include rules for storage of the sample and downstream byproducts, for safe disposal after they are no longer needed and contingency plans in case of spills and accidental release; (v) Detection, interpretation of results, and reporting (SOPs for identification of viruses, establish turn-around times, and actual reporting of results); and (vi) a clear contingency plan for reacting when nonvaccine polioviruses are detected. 
In almost all cases, the amount of poliovirus in sewage is low, and detection requires a concentration step (WHO, 2015a). Concentration procedures include (i) a two phase separation after addition of Dextran T40 and PEG 6000 to the sewage (can easily be implemented in all laboratories of the GPLN); (ii) $\mathrm{PEG} 600 / \mathrm{NaCl}$ precipitation (requires heavy centrifuge and rotors not available in all labs); and (iii) Tangential Flow Ultrafiltration (currently being evaluated). Of the 3 , the latter may provide the best solution since early trials indicate much higher viral recovery and it offers the possibility of on-site use to significantly reduce one of the current bottlenecks of environmental surveillance, e.g., the need to store and transport large volumes of contaminated sewage under cold chain conditions).

The WHO standard detection protocol (WHO, 2015a) requires viral isolation by tissue culture. The cell lines used, the number of replicate cultures used for viral challenge, and the inoculation volumes an even the number of days post-inoculation have not yet been standardized and these all influence results especially when virus is in low concentration.

Three examples will be briefly presented to show the usefulness of environmental surveillance in the GPEI; environmental surveillance in Egypt (Blomqvist et al., 2012; El Bassioni et al., 2003; Hovi et al., 2005; WHO, 2013b), in Israel (Hindiyeh et al., 2014; Manor et al., 2007 ; Manor et al., 1999; Manor et al., 2014; Moran-Gilad et al., 2015; Shulman et al., 2014a; Shulman et al., 2006; Shulman et al., 2012; Shulman et al., 2014b;; WHO, 2013c) and in Finland/Slovakia/Estonia (Blomqvist et al., 2004; Hovi et al., 2013; Hovi et al., 2012; Roivainen et al., 2010).

In Egypt, environmental surveillance was initiated in September 2000 while wild poliovirus was still endemic but in the last stages of elimination. Results in 2001-2002 revealed widespread silent circulation of wild type 1 poliovirus, helped to identify gaps in routine AFP surveillance, and was helpful in targeting surveillance and immunization so that by the end of 2006 Egypt was successful in eliminating endemic circulation of wild polio. In 2005 and 2010 type 2 vaccine derived polioviruses excreted by anonymous individuals (aVDPVs) were isolated and wild type 1 polio originating from Pakistan was isolated from sewage in Cairo in December 2012.

Countrywide routine monthly environmental surveillance was initiated in Israel in 1989 in response to the last outbreak of poliomyelitis from wild poliovirus. Environmental surveillance identified the introduction, local silent circulation of wild polio, and documented the successful efforts to control the circulation with tOPV in the Gaza District between 1995-96 (Manor et al., 1999 Shulman et al., 2012). Advanced molecular analysis techniques were developed to distinguish between multiple introductions of wild poliovirus and local endemic circulation (Manor et al., 2007). In 2005 Israel switched to exclusive use of inactivated polio vaccine for routine polio vaccination and OPV strains disappeared from sewage within a few months. Between 1998 and 2014, neurovirulent, vaccine derived polioviruses (aVDPVs) were periodically isolated from sewage from central Israel, once in Jerusalem, and twice from Haifa. Molecular analysis suggested that the aVDPVs were excreted by at least three different persistently infected immune-deficient individuals (Shulman et al., 2006). After 2005 when sewage was OPVfree, all polio that was isolated was of potential interest. Plaque assay was used to indicate the amount of virus recovered from each sewage sample. During this time, the highly sensitive environmental surveillance used in Israel enabled tracking of the location of the individuals who were excreting the aVDPVs as they moved from city-to-city and even within a single city (Shulman et al., 2012). Finally, in 2013, environmental surveillance detected a sharp rise in the number of poliovirus plaques that analysis confirmed as wild type 1 (WPV1) (Manor et al., 2014). Sequence and phylogenetic analysis revealed that the imported wild type 1 poliovirus originated from Pakistan and was closely related to the wild type 1 poliovirus isolated in December 2012 in Cairo from sewage (Shulman et al., 2014a). Poliovirus isolated from AFP cases in Syria in 2014 were also related to the viruses in Israel and Egypt (WHO, 2013c). Specific RT-PCR primers were designed to detect this wild type virus by environmental surveillance (Hindiyeh et al., 2014). More importantly these primers and probe were validated for use in semi-quantitative analysis of RNA extracted directly from concentrated sewage allowing an initial turn-around time of a week after sewage collection (Hindiyeh et al., 2014; Manor et al., 2014; Shulman et al., 2014b). Results were confirmed by standard tissue culture two weeks later. The results from qRT-PCR were correlated with the number of plaques so that when the environment became flooded with OPV strains after supplementary immunization activity (SIA) with bivalent OPV (OPV without a serotype 2 component) in August 2013, plaque-equivalent wild poliovirus loads could continue to be provided to the Israel Polio Oversight Committee for outbreak control. The environmental surveillance helped successfully pinpoint the epicenter of silent circulation and target the cohort with the highest probability of detecting silent circulation by stool survey of identified individuals (Moran-Gilad et al., 2015; Shulman et al., 2014b). The Polio Regional Certification Committee (RCC) required that the same sensitive methods that had been used to identify the silent circulation of the WPV, be used to document its disappearance during the 12 months after the last positive environmental surveillance sample was collected on April 3rd 2014 before Israel could be declared WPV1-free. As a consequence of very high population immunity to polio $(>95 \%$,$) , there were no polio-AFP cases throughout the$ entire episode (Feb 2013- April 2015).

The Polio Laboratory in Finland recovered highly diverged aVDPVs from sewage in Finland, Slovakia and Estonia over extended periods of time (Blomqvist et al., 2004; Hovi et al., 2013; Hovi et al., 2012; Roivainen et al., 2010). Molecular analysis strongly suggested that immunedeficient individuals were shedding these VDPVs. These findings may indicate that persistent excretors may be less rare than believed on the basis of identification of known persistent excretors and failed efforts to identify new ones by screening immune deficient individuals in multinational studies. Environmental surveillance also documented the cessation of an extended shedding of a type 2 VDPV without intervention or identification of the shedder (Hovi et al., 2013). 
There are a number of challenges for ENVS that need to be addressed. In the field these include interpretation of data from open sewers where water flow, depth and contamination and the number of persons in the catchment area are poorly documented, unknown effects of pooling samples from different locations to reduce workload, and the high cost and difficulty of transporting large volumes of sewage within and between countries in time frames that results will be are relevant for intervention. In the lab they include space personnel and interpretation of data especially negative results. On-site processing would help to alleviate some of these difficulties. In the lab they involve the process of virus concentration, elution from particles and filters, and reduction of co-extraction of inhibitors.

In conclusion ENVS will be a critical element of surveillance during polio eradication and in the post eradication era. It will play an important role in polioendemic countries, countries where poliovirus has been reintroduced and in polio-free countries. It is especially helpful in countries where there is sub-optimal AFP surveillance and high risk for transmission and for countries with very high vaccine coverage (the example given here is Israel) where there is a significantly reduced likelihood for development of poliomyelitis after infection with neurovirulent poliovirus strains and risk of much higher numbers of silent infections by non-vaccine polioviruses before any cases occur. The World Health Organization has recommended a global cessation of the use of live serotype two in OPV vaccines by April 2016 and withdrawal of the use all live vaccine strains within two years of the last case of poliomyelitis from wild poliovirus (WHO, 2015b). Environmental surveillance is especially important for populations with high IPV vaccine coverage, since the ratio of AFP cases to asymptomatic infections would be orders of magnitude lower than for under-vaccinated populations. The objective of ENVS for eradication is to measure disappearance of endemic strains, imported strains, finally live vaccine strains and to provide early warning of importation or re-emergence. Sewage samples from the polio ENVS can be and have been used to identify circulation of other enteric viruses. 


\section{References}

Abbaszadegan, M., LeChevallier, M. and Gerba, C. (2003). Occurrence of Viruses in US Groundwaters (PDF). Journal American Water Works Association. 95, American Water Works Association. pp. 107-120.

Akin, E.W., Hoff, J.C. and Lippy, E.C. (1982). Waterborne outbreak control: which disinfectant?. Environmental Health Perspectives. 46, pp. 7-12.

Alcala, A., Vizzi, E., Rodríguez-Díaz, J., Zambrano, J.L., Betancourt, W. and Liprandi, F. (2010). Molecular detection and characterization of Aichi viruses in sewage-polluted waters of Venezuela. Applied and Environmental Microbiology. 76, pp. 4113-5. doi: 10.1128/AEM.00501-10 AEM.00501-10 [pii].

Alexander, J.P., Gary, H.E. and Pallansch, M.A. (1997). Duration of poliovirus excretion and its implications for acute flaccid paralysis surveillance: a review of the literature. The Journal of Infectious Diseases. 175 Suppl 1, pp. S176-82.

Ali, M.A., Al-Herrawy, A.Z. and El-Hawaary, S.E. (2004). Detection of enteric viruses, Giardia and Cryptosporidium in two different types of drinking water treatment facilities. Water Research. 38, pp. 3931-3939.

Amdiouni, H., Faouzi, A., Fariat, N., Hassar, M., Soukri, A. and Nourlil, J. (2012). Detection and molecular identification of human adenoviruses and enteroviruses in wastewater from Morocco. Letters in Applied Microbiology. 54, pp. 359-66. doi: 10.1111/j.1472-765X.2012.03220.x.

Anderson, D.A. and Counihan, N.A. (2011). Hepatitis A and E viruses. Manual of Clinical Microbiology. American Society for Microbiology. Washington, DC. pp. 423-1436.

Anonymous (2015). Aerated Lagoons and Stabilization Ponds. Mountain Empire Community College, VA. http://water.me.vccs.edu/courses/env149/stabilization.htm Last accessed July 2015.

Anonymous (2015). Water Introduction to Wastewater Treatment Processes. World Bank Group http://water.worldbank.org/shw-resource-guide/infrastructure/menu-technical-options/wastewater-treatment last accessed July 2015.

Antony, A., Blackbeard, J. and Leslie, G. (2012). Removal Efficiency and Integrity Monitoring Techniques for Virus Removal by Membrane Processes. Critical Reviews in Environmental Science and Technology. 42, pp. 891-933.

Arnold, B.F., Schiff, K.C., Griffith, J.F., Gruber, J.S., Yau, V., Wright, C.C. et al. (2013). Swimmer illness associated with marine water exposure and water quality indicators: impact of widely used assumptions. Epidemiology. 24, pp. 845-53. doi: 10.1097/01.ede.0000434431.06765.4a.

Asahina, A.Y., Lu, Y., Wu, C., Fujioka, R.S. and Loh, P.C. (2009). Potential biosentinels of human waste in marine coastal waters: bioaccumulation of human noroviruses and enteroviruses from sewage-polluted waters by indigenous mollusks. Journal of Virological Methods. 158, pp. 46-50. doi: 10.1016/j.jviromet.2009.01.013.

Aw, T.G. and Gin, K.Y. (2010). Environmental surveillance and molecular characterization of human enteric viruses in tropical urban wastewaters. Journal of Applied Microbiology. 109, pp. 716-730.

Aw, T.G., Howe, A. and Rose, J.B. (2014). Metagenomic approaches for direct and cell culture evaluation of the virological quality of wastewater. Journal of Virological Methods. 210C, pp. 15-21.

Battistone, A., Buttinelli, G., Fiore, S., Amato, C., Bonomo, P., Patti, A.M. et al. (2014). Sporadic isolation of sabin-like polioviruses and high-level detection of non-polio enteroviruses during sewage surveillance in seven Italian cities, after several years of inactivated poliovirus vaccination. Applied and Environmental Microbiology. 80, pp. 4491-501. doi: AEM.00108-14 [pii] 10.1128/AEM.00108-14.

Begier, E.M., Oberste, M.S., Landry, M.L., Brennan, T., Mlynarski, D., Mshar, P.A. et al. (2008). An outbreak of concurrent echovirus 30 and coxsackievirus A1 infections associated with sea swimming among a group of travelers to Mexico. Clinical Infectious Diseases. 47, pp. 616-23. doi: 10.1086/590562. 
Berger, W. (2011). Technology review of composting toilets Basic overview of composting toilets (with or without urine diversion). Deutsche Gesellschaft für Internationale Zusammenarbeit (GIZ) GmbH Sustainable sanitation - ecosan program Postfach 5180, 65726 Eschborn, Germany; http://www.susana.org/en/resources/library/details/878 Last Accessed July 2015.

Berg, G. and Berman, D. (1980). Destruction by anaerobic mesophilic and thermophilic digestion of viruses and indicator bacteria indigenous to domestic sludges. Applied and Environmental Microbiology. 39, pp. 361-368.

Berg, G., Sullivan, G. and Venosa, A.D. (1988). Low-temperature stability of viruses in sludges. Applied and Environmental Microbiology. 54, pp. 839-41.

Bertrand, I., Schijven, J.F., Sanchez, G., Wyn-Jones, P., Ottoson, J., Morin, T. et al. (2012). The impact of temperature on the inactivation of enteric viruses in food and water: a review. Journal of Applied Microbiology. 112, pp. 1059-74. doi: 10.1111/j.1365-2672.2012.05267.x.

Betancourt, W.Q., Kitajima, M., Wing, A.D., Regnery, J., Drewes, J.E., Pepper, I.L. et al. (2014). Assessment of virus removal by managed aquifer recharge at three full-scale operations. Journal of Environmental Science and Health. 49, pp. 1685-92. doi: 10.1080/10934529.2014.951233.

Betancourt, W.Q., Saavedra, M. and Moncho, A. (2015). Poliovirus and nonpolio enterovirus loads associated with sewagepolluted waters and tropical coastal marine environments that receive multiple sewage discharges. Final Report. Submitted to the Venezuelan Ministry of Science, Technology and Education.

Bibby, K. and Peccia, J. (2013). Identification of viral pathogen diversity in sewage sludge by metagenome analysis. Environmental Science and Technology. 47, pp. 1945-1951.

Biziagos, E., Passagot, J., Crance, J.M. and Deloince, R. (1988). Long-term survival of hepatitis A virus and poliovirus type 1 in mineral water. Applied and Environmental Microbiology. 54, pp. 2705-2710.

Blatchley III, E.R., Gong, W.L., Alleman, J.E., Rose, J.B., Huffman, D.E., Otaki, M. et al. (2007). Effects of wastewater disinfection on waterborne bacteria and viruses. Water Environmental Research. 79, pp. 81-92.

Blinkova, O., Rosario, K., Li, L., Kapoor, A., Slikas, B., Bernardin, F. et al. (2009). Frequent detection of highly diverse variants of cardiovirus, cosavirus, bocavirus, and circovirus in sewage samples collected in the United States. Journal of Clinical Microbiology. 47, pp. 3507-13. doi: 10.1128/JCM.01062-09.

Boehm, A.B., Fuhrman, J.A., Mrse, R.D. and Grant, S.B. (2003). Tiered approach for identification of a human fecal pollution source at a recreational beach: case study at Avalon Bay, Catalina Island, California. Environmental Science and Technology. 37, pp. 673-680.

Boehm, A.B., Ashbolt, N.J., Colford, Jr., J.M., Dunbar, L.E., Fleming, L.E., Gold, M.A. et al. (2009). A sea change ahead for recreational water quality criteria. Journal of Water and Health. 7, pp. 9-20. doi: 10.2166/wh.2009.122.

Borchardt, M.A., Bertz, P.D., Spencer, S.K. and Battigelli, D.A. (2003). Incidence of enteric viruses in groundwater from household wells in Wisconsin. Applied and Environmental Microbiology. 69, pp. 1172-80.

Borchardt, M.A., Bradbury, K.R., Gotkowitz, M.B., Cherry, J.A. and Parker, B.L. (2007). Human enteric viruses in groundwater from a confined bedrock aquifer. Environmental Science and Technology. 41, pp. 6606-12.

Borchardt, M.A., Spencer, S.K., Kieke, B.A., Lambertini, E. and Loge, F.J. (2012). Viruses in nondisinfected drinking water from municipal wells and community incidence of acute gastrointestinal illness. Environmental Health Perspectives. 120, pp. 1272-9.

Borchardt, M.A., Haas, N.L. and Hunt, R.J. (2004). Vulnerability of drinking-water wells in La Crosse, Wisconsin, to entericvirus contamination from surface water contributions. Applied and Environmental Microbiology. 70, pp. 5937-46. doi: 10.1128/AEM.70.10.5937-5946.2004.

Bosch, A., Abad, F.X. and Pinto, R.M. (2005). Human Pathogenic Viruses in the Marine Environment. Oceans and Health: 
Pathogens in the Marine Environment. (Belkin, S. and Colwel, R.R., ed.). Springer. New York, NY, USA. pp. 109-131.

Bosch, A., Pinto, R.M. and Abad, F.X. (2006). Survival and transport of enteric viruses in the environment. Viruses in Foods. Food Microbiology and Food Safety Series. (Goyal, S.M., ed.). Springer. New York, NY, USA. pp. 151-187.

Burton, N.C. and Dowell, C.D. (2011). Health hazard evaluation report: evaluation of exposures associated with cleaning and maintaining composting toilets - Arizona. U.S. Department of Health and Human Services, Centers for Disease Control and Prevention, National Institute for Occupational Safety and Health.

Butler, D. and Smith, S.R. (2002). Septic tank systems. Bitton G. Encyclopedia of environmental microbiology. John Wiley and Sons. New York, NY, USA. pp. 2853-2864.

Callahan, K.M., Taylor, D.J. and Sobsey, M.D. (1995). Comparative survival of hepatitis A virus, poliovirus and indicator viruses in geographically diverse seawaters. Water Science and Technology. 31, pp. 189-193.

Cantalupo, P.G., Calgua, B., Zhao, G., Hundesa, A., Wier, A.D., Katz, J.P. et al. (2011). Raw sewage harbors diverse viral populations. MBio. 2(5), pp. e00180-11.

Canter, L.W. and Knox, R.C. (1985). Septic tank systems effects on ground water quality. Lewis Publishers. Chelsea, Michigan.

Cardosa, M.J., Perera, D., Brown, B.A., Cheon, D., Chan, H.M., Chan, K.P. et al. (2003). Molecular epidemiology of human enterovirus 71 strains and recent outbreaks in the Asia-Pacific region: comparative analysis of the VP1 and VP4 genes. Emerging Infectious Diseases. 9, pp. 461-468.

Carter, M.J. (2005). Enterically infecting viruses: pathogenicity, transmission and significance for food and waterborne infection. Journal of Applied Microbiology. 98, pp. 1354-1380.

Cashdollar, J.L. and Wymer, L. (2013). Methods for primary concentration of viruses from water samples: a review and meta-analysis of recent studies. Journal of Applied Microbiology. 115, pp. 1-11. doi: 10.1111/jam.12143.

CDC (2011). Clusters of Acute Respiratory Illness Associated with Human Enterovirus 68 -- Asia, Europe, and United States, 2008-2010. Morbidity and Mortality Weekly Report. 60, pp. 1301-1304.

Chapron, C.D., Ballester, N.A., Fontaine, J.H., Frades, C.N. and Margolin, A.B. (2000). Detection of astroviruses, enteroviruses, and adenovirus types 40 and 41 in surface waters collected and evaluated by the information collection rule and an integrated cell culture-nested PCR procedure. Applied and Environmental Microbiology. 66, pp. 2520-5.

Chen, C.H., Hsu, B.M. and Wan, M.T. (2008). Molecular detection and prevalence of enterovirus within environmental water in Taiwan. Journal of Applied Microbiology. 104, pp. 817-823. doi: 10.1111/j.1365-2672.2007.03598.x.

Chlorine Chemistry Council (2003). Drinking Water Chlorination A Review of Disinfection Practices and Issues. Water Quality and Health Council.

Cho, H.U., Park, S.K., Ha, J.H. and Park, J.M. (2013). An innovative sewage sludge reduction by using a combined mesophilic anaerobic and thermophilic aerobic process with thermal-alkaline treatment and sludge recirculation. Journal of Environmental Management. 129, pp. 274-82. doi: 10.1016/j.jenvman.2013.07.009.

Chong, S., Sen, T.K., Kayaalp, A. and Ang, H.M. (2012). The performance enhancements of upflow anaerobic sludge blanket (UASB) reactors for domestic sludge treatment-a state-of-the-art review. Water Research. 46, pp. 3434-70. doi: 10.1016/j.watres.2012.03.066.

Chonmaitree, T., Ford, C., Sanders, C. and Lucia, H.L. (1988). Comparison of cell cultures for rapid isolation of enteroviruses. Journal of Clinical Microbiology. 26, pp. 2576-80.

Choo, Y.J. and Kim, S.J. (2006). Detection of human adenoviruses and enteroviruses in Korean oysters using cell culture, integrated cell culture-PCR, and direct PCR. Journal of Microbiology. 44, pp. 162-70. 
Chung, H. and Sobsey, M.D. (1993). Comparative survival of indicator viruses and enteric viruses in seawater and sediment. Water Science and Technology. 27, pp. 425-428.

Chung, P.W., Huang, Y.C., Chang, L.Y., Lin, T.Y. and Ning, H.C. (2001). Duration of enterovirus shedding in stool. Journal of Microbiology, Immunology, and Infection. 34, pp. 167-70.

Condit, R.C., Knipe, D.M., Howley, P.M., I, C.J., Griffin, D.E., Lamb, R.A. et al. (2013). Principles of Virology. Fields Virology, Sixth Edition. Wolters Klewer / Lippincott Williams and Wilkins. Philadelphia. pp. 21-25.

Connell, C., Tong, H.I., Wang, Z., Allmann, E. and Lu, Y. (2012). New approaches for enhanced detection of enteroviruses from Hawaiian environmental waters. PLoS One. 7, pp. e32442. doi: 10.1371/journal.pone.0032442.

Costan-Longares, A., Mocé-Llivina, L., Avellon, A., Jofre, J. and Lucena, F. (2008). Occurrence and distribution of culturable enteroviruses in wastewater and surface waters of north-eastern Spain. Journal of Applied Microbiology. 105, pp. 1945-55. doi: 10.1111/j.1365-2672.2008.03954.x.

Cutler, T.D. and Zimmerman, J.J. (2011). Ultraviolet irradiation and the mechanisms underlying its inactivation of infectious agents. Animal Health Research Reviews. 12, pp. 15-23. doi: 10.1017/S1466252311000016.

De la Rubia, M.A., Riau, V., Raposo, F. and Borja, R. (2013). Thermophilic anaerobic digestion of sewage sludge: focus on the influence of the start-up. A review. Critical Reviews in Biotechnology. 33, pp. 448-60. doi: 10.3109/07388551.2012.726962.

Deng, M.Y. and Cliver, D.O. (1992). Inactivation of poliovirus type 1 in mixed human and swine wastes and by bacteria from swine manure. Applied and Environmental Microbiology. 58, pp. 2016-2021.

DEP (2011). 4-Log Treatment of Viruses Demonstration Guidance 385-2125-001. Pennsylvania's Safe Drinking Water Act (35 P.S. §721.1 et. seq.) and regulations at 25 Pa. Code Chapter 109. Pennsylvania Department of Environmental Protection.

De Roda Husman, A.M., Lodder, W.J., Rutjes, S.A., Schijven, J.F. and Teunis, P.F. (2009). Long-term inactivation study of three enteroviruses in artificial surface and groundwaters, using PCR and cell culture. Applied and Environmental Microbiology. 75, pp. 1050-7. doi: 10.1128/AEM.01750-08.

Doederer, K., Gernjak, W., Weinberg, H.S. and Farre, M.J. (2014). Factors affecting the formation of disinfection byproducts during chlorination and chloramination of secondary effluent for the production of high quality recycled water. Water Res. 48, pp. 218-28. doi: 10.1016/j.watres.2013.09.034 S0043-1354(13)00726-4 [pii].

Donaldson, K.A., Griffin, D.W. and Paul, J.H. (2002). Detection, quantitation and identification of enteroviruses from surface waters and sponge tissue from the Florida Keys using real-time RT-PCR. Water Res. 36, pp. 2505-14.

Dowdle, W.R. and Birmingham, M.E. (1997). The biologic principles of poliovirus eradication. The Journal of Infectious Diseases. 175 Suppl 1, pp. S286-92.

Dowdle, W.R., de Gourville, E., Kew, O.M., Pallansch, M.A. and Wood, D.J. (2003). Polio eradication: the OPV paradox. Rev Med Virol. 13, pp. 277-91. doi: 10.1002/rmv.401.

Dowdle, W.R., Gary, H.E., Sanders, R. and van Loon, A.M. (2002). Can post-eradication laboratory containment of wild polioviruses be achieved?. Bulletin of the World Health Organization. 80,.

Dowdle, W., van der Avoort, H., de Gourville, E., Delpeyroux, F., Desphande, J., Hovi, T. et al. (2006). Containment of polioviruses after eradication and OPV cessation: characterizing risks to improve management. Risk Anal. 26, pp. 1449-69.

Duboise, S.M., Moore, B.E. and Sagik, B.P. (1976). Poliovirus survival and movement in a sandy forest soil. Applied and Environmental Microbiology. 31, pp. 536-43.

Duizer, E. (2015). Laboratory analysis of environmental samples taken following the reported release of live poliovirus. pp. $1-23$. 
Dumontet, S., Dinel, H. and Baloda, S.B. (1999). Pathogen reduction in sewage sludge by composting and other biological treatments: A review. Biological Agriculture and Horticulture. 16, pp. 409-430.

Dunn, G., Klapsa, D., Wilton, T., Stone, L., Minor, P.D. and Martin, J. (2015). Twenty-Eight Years of Poliovirus Replication in an Immunodeficient Individual: Impact on the Global Polio Eradication Initiative. PLoS pathogens. 11, pp. e1005114. doi: 10.1371/journal.ppat.1005114.

Dupuy, C., Mallet, C., Guizien, K., Montanie, H., Breret, M., Mornet, F. et al. (2014). Sequential resuspension of biofilm components (viruses, prokaryotes and protists) as measured by erodimetry experiments in the Brouage mudflat (French Atlantic coast). 92, Elsevier http://archimer.ifremer.fr/doc/00168/27922/ last accessed July 2015. pp. 56-65.

Dyble, J., Bienfang, P., Dusek, E., Hitchcock, G., Holland, F., Laws, E. et al. (2008). Environmental controls, oceanography and population dynamics of pathogens and harmful algal blooms: connecting sources to human exposure. Environmental Health. 7 Suppl 2, pp. S5. doi: 10.1186/1476-069X-7-S2-S5.

ECDC (2014). Monitoring current threats: ECDC Communicable Disease Threats Report (CDTR), week 37/2014. ECDC http://ecdc.europa.eu/en/press/news/_layouts/forms/News_DispForm.aspx?List=8db7286cfe2d-476c-9133-18ff4cb1b568\&amp;ID=1065\#sthash.j3JYS80A.dpuf Last Accessed July 2015.

Ehlers, M.M., Grabow, W.O. and Pavlov, D.N. (2005). Detection of enteroviruses in untreated and treated drinking water supplies in South Africa. Water Res. 39, pp. 2253-8. doi: 10.1016/j.watres.2005.04.014.

Engelbrecht, R.S., Weber, M.J., Salter, B.L. and Schmidt, C.A. (1980). Comparative inactivation of viruses by chlorine. Applied and Environmental Microbiology. 40, pp. 249-56.

Feachem, R.G., Bradley, D.J., Garelick, H. and Mara, D.D. (1983). Sanitation and Disease Health Aspects of Excreta and Wastewater Management. John Wiley and Sons, Inc.

Feachem, R.G., Bradley, D.J., Garelick, H. and Mara, D. (1980). Health Aspects of Excreta and Sullage Management - A State-of-the-art Review. World Bank, Transportation, Water, and Telecommunications Department. Washington, D.C.

Flannery, J., Keaveney, S., Rajko-Nenow, P., O'Flaherty, V. and Dore, W. (2012). Concentration of norovirus during wastewater treatment and its impact on oyster contamination. Applied and Environmental Microbiology. 78, pp. 3400-6. doi: 10.1128/AEM.07569-11 AEM.07569-11 [pii].

Fong, T.T. and Lipp, E.K. (2005). Enteric viruses of humans and animals in aquatic environments: health risks, detection, and potential water quality assessment tools. Microbiology and Molecular Biology Reviews. 69, pp. 357-371. doi: 10.1128/MMBR.69.2.357-371.2005.

Fong, T.T., Griffin, D.W. and Lipp, E.K. (2005). Molecular assays for targeting human and bovine enteric viruses in coastal waters and their application for library-independent source tracking. Applied and Environmental Microbiology. 71, pp. 2070-2078. doi: 71/4/2070 [pii] 10.1128/AEM.71.4.2070-2078.2005.

Fong, T.T. and Lipp, E.K. (2005). Enteric viruses of humans and animals in aquatic environments: health risks, detection, and potential water quality assessment tools. Microbiology and Molecular Biology Reviews. 69, pp. 357-71. doi: 10.1128/MMBR.69.2.357-371.2005.

Fout, G.S., III, F.W.Schaefe, Messer, J.W., Dahling, D.R. and Stetler, R.E. (1996). ICR Microbial Laboratory Manual E P A / 600 / R - $95 / 178$.

https://www.google.com/url?sa=t\&amp;rct=j\&amp;q=\&amp;esrc=s\&amp;source=web\&amp;cd=1\&amp;ved=0CB0QFjAA ahUKEwjEu7j_ur7HAhWCWhQKHbMrAoE\&amp;url=http\%3A\%2F\%2Fwww.epa.gov\%2Fnerlcwww\%2Fdocuments\%2Ficrm

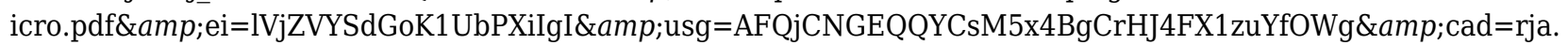

Fout, G.S., Martinson, B.C., Moyer, M.W. and Dahling, D.R. (2003). A multiplex reverse transcription-PCR method for detection of human enteric viruses in groundwater. Applied and Environmental Microbiology. 69, pp. 3158-64.

Francy, D.S., Stelzer, E.A., Bushon, R.N., Brady, A.M., Williston, A.G., Riddell, K.R. et al. (2012). Comparative effectiveness of membrane bioreactors, conventional secondary treatment, and chlorine and UV disinfection to remove microorganisms from municipal wastewaters. Water Research. 46, pp. 4164-78. 
Francy, D.S., Stelzer, E.A., Bushon, R.N., Brady, A.M.G., Williston, A.G., Riddell, K.R. et al. (2012). Comparative effectiveness of membrane bioreactors, conventional secondary treatment, and chlorine and UV disinfection to remove microorganisms from municipal wastewaters. Water Research. 46, Elsevier Ltd. pp. 4164-4178. doi: 10.1016/j.watres.2012.04.044.

Fuhrman, J.A., Liang, X. and Noble, R.T. (2005). Rapid detection of enteroviruses in small volumes of natural waters by real-time quantitative reverse transcriptase PCR. Applied and Environmental Microbiology. 71, pp. 4523-30. doi: 10.1128/AEM.71.8.4523-4530.2005.

Fujioka, R.S. and Yoneyama, B.S. (2002). Sunlight inactivation of human enteric viruses and fecal bacteria. Water Sci Technol. 46, pp. 291-5.

Gantzer, C., Senouci, S., Maul, A., Levi, Y. and Schwartzbrod, L. (1997). Enterovirus genomes in wastewater: concentration on glass wool and glass powder and detection by RT-PCR. Journal of Virological Methods. 65, pp. 265-71.

Gaulke, L.S. (2006). On-site wastewater treatment and reuses in Japan. Water Management. 159, pp. 103-109.

Gerba, C.P. (2000). Assessment of enteric pathogen shedding during recreational activity and its impact on water quality. Quantitative Microbiology. pp. 55-68.

Gerba, C.P. (2006). Survival of viruses in the marine environment. Ocean and Health. (Belkin, S. and Colwell, R., ed.). Springer. New York, NY, USA. pp. 133-142.

Gerba, C.P. (2007). Virus occurrence and survival in the environmental waters. Human Viruses in Water. (Bosch, A., ed.). Elsevier. Amsterdam, The Netherlands. pp. 91 - 108.

Gerba, C.P., Kitajima, M. and Iker, B.C. (2007). Viral presence in waste water and sewage and control methods. Amsterdam. pp. 293-315.

Gerba, C.P., Kitajima, M. and Iker, B.C. (2013). Viral presence in waste water and sewage and control methods. Food and Water: Risks, Surveillance and Control. (Cook, N., ed.). Woodhead Publishing Ltd. Cambridge, UK. pp. $293-315$.

Gersberg, R.M., Lyon, S.R., Brenner, R. and Elkins, B.V. (1987). Fate of viruses in artificial wetlands. Appl Environ Microbiol. 53, pp. 731-6.

Gersberg, R.M., Rose, M.A., Robles-Sikisaka, R. and Dhar, A.K. (2006). Quantitative detection of hepatitis a virus and enteroviruses near the United States-Mexico border and correlation with levels of fecal indicator bacteria. Applied and Environmental Microbiology. 72, pp. 7438-44. doi: 10.1128/AEM.01024-06.

Gibbons, C.D., Rodriguez, R.A., Tallon, L. and Sobsey, M.D. (2010). Evaluation of positively charged alumina nanofibre cartridge filters for the primary concentration of noroviruses, adenoviruses and male-specific coliphages from seawater. Journal of Applied Microbiology. 109, pp. 635-41. doi: 10.1111/j.1365-2672.2010.04691.x.

Gibson, K.E. (2014). Viral pathogens in water: occurrence, public health impact, and available control strategies. Current Opinion in Virology. 4, pp. 50-57.

Gibson, K.E. and Schwab, K.J. (2011). Tangential-flow ultrafiltration with integrated inhibition detection for recovery of surrogates and human pathogens from large-volume source water and finished drinking water. Applied and Environmental Microbiology. 77, pp. 385-91. doi: 10.1128/AEM.01164-10.

Goddard, M.R., Bates, J. and Butler, M. (1981). Recovery of indigenous enteroviruses from raw and digested sewage sludges. Applied and Environmental Microbiology. 42, pp. 1023-8.

Gomila, M., Solis, J.J., David, Z., Ramon, C. and Lalucat, J. (2008). Comparative reductions of bacterial indicators, bacteriophage-infecting enteric bacteria and enteroviruses in wastewater tertiary treatments by lagooning and UVradiation. Water Science and Technology : a journal of the International Association on Water Pollution Research. 58, pp. 2223-33. doi: 10.2166/wst.2008.584. 
Gordon, C. and Toze, S. (2003). Influence of groundwater characteristics on the survival of enteric viruses. J Appl Microbiol. 95, pp. 536-44.

Goyal, S.M., Schaub, S.A., Wellings, F.M., Berman, D., Glass, J.S., Hurst, C.J. et al. (1984). Round robin investigation of methods for recovering human enteric viruses from sludge. Applied and Environmental Microbiology. 48, pp. 531-538.

Grabow, W.O.K. (2007). Overview of health-related water virology. Human Viruses in Water. (Bosch, A., ed.). Elsevier, Amsterdam. Amsterdam, The Netherlands. pp. 1 - 25.

Graham, J.P. and Polizzotto, M.L. (2013). Pit latrines and their impacts on groundwater quality: a systematic review. Environ Health Perspect. 121, pp. 521-30. doi: 10.1289/ehp.1206028.

Gregory, J.B., Litaker, R.W. and Noble, R.T. (2006). Rapid one-step quantitative reverse transcriptase PCR assay with competitive internal positive control for detection of enteroviruses in environmental samples. Appl Environ Microbiol. 72, pp. 3960-7. doi: 10.1128/AEM.02291-05.

Greninger, A.L., Runckel, C., Chiu, C.Y., Haggerty, T., Parsonnet, J., Ganem, D. et al. (2009). The complete genome of klassevirus - a novel picornavirus in pediatric stool. Virol J. 6, pp. 82. doi: 10.1186/1743-422X-6-82.

Griffin, D.W., Donaldson, K.A., Paul, J.H. and Rose, J.B. (2003). Pathogenic human viruses in coastal waters. Clinical Microbiology Reviews. 16, pp. 129-43.

Guardabassi, L., Dalsgaard, A. and Sobsey, M. (2003). Occurrence and survival of viruses in composted human feces. Sustainable Urban Renewal and Wastewater Treatment No 32. Denmark. Danish Environmental Protection Agency, Danish Ministry of the Environment.

Guzmán, C., Jofre, J., Montemayor, M. and Lucena, F. (2007). Occurrence and levels of indicators and selected pathogens in different sludges and biosolids. Journal of Applied Microbiology. 103, pp. 2420-9. doi: $10.1111 / \mathrm{j} .1365-2672.2007 .03487 . \mathrm{x}$.

Haas, C.N., Rose, J.B., Gerba, C. and Regli, S. (1993). Risk assessment of virus in drinking water. Risk Analysis: an Official Publication of the Society for Risk Analysis. 13, pp. 545-52.

Haas, C.N., Rose, J.B. and Gerba, C.P. (1999). Quantitative microbial risk assessment. Wiley. New York, NY, USA. pp. x, $449 \mathrm{p}$.

Hagedorn, C. (1994). Microbiological aspects of groundwater pollution due to septic tanks. Groundwater Pollution Microbiology. (Bitton, G. and Gerba, C.P., ed.). Krieger Publishing Company. Malabar, FL. pp. 181-195.

Hamza, I.A., Jurzik, L., Stang, A., Sure, K., Uberla, K. and Wilhelm, M. (2009). Detection of human viruses in rivers of a densly-populated area in Germany using a virus adsorption elution method optimized for PCR analyses. Water Research. 43, pp. 2657-2668. doi: 10.1016/j.watres.2009.03.020.

Haramoto, E. and Otagiri, M. (2013). Occurrence of Human Cosavirus in Wastewater and River Water in Japan. Food and Environmental Virology. pp. 62-66. doi: 10.1007/s12560-013-9120-6.

Haramoto, E., Katayama, H., Oguma, K. and Ohgaki, S. (2005). Application of cation-coated filter method to detection of noroviruses, enteroviruses, adenoviruses, and torque teno viruses in the Tamagawa River in Japan. Applied and Environmental Microbiology. 71, pp. 2403-11. doi: 10.1128/AEM.71.5.2403-2411.2005.

Harvala, H., Calvert, J., Van Nguyen, D., Clasper, L., Gadsby, N., Molyneaux, P. et al. (2014). Comparison of diagnostic clinical samples and environmental sampling for enterovirus and parechovirus surveillance in Scotland, 2010 to 2012. Euro Surveillance. 19, pp. 1-9.

Harvala, H. and Simmonds, P. (2009). Human parechoviruses: biology, epidemiology and clinical significance. Journal of Clinical Virology. 45, pp. 1-9. doi: 10.1016/j.jcv.2009.03.009.

Harwood, V.J., Levine, A.D., Scott, T.M., Chivukula, V., Lukasik, J.,. et al. (2005). Validity of the indicator organism 
paradigm for pathogen reduction in reclaimed water and public health protection. Applied and Environmental Microbiology. 71, pp. 3163-3170.

Hegazy, A.M., El-Salakawy, A.H., Shaban, M.M., Yehia, M.M. and AbuSalama, M.S. (2013). Eco-friendly management of enteroviruses in wastewater. Water Science. 27, pp. 19-29.

Hewitt, J., Leonard, M., Greening, G.E. and Lewis, G.D. (2011). Influence of wastewater treatment process and the population size on human virus profiles in wastewater. Water Research. 45, pp. 6267-76.

Hijnen, W.A., Beerendonk, E.F. and Medema, G.J. (2006). Inactivation credit of UV radiation for viruses, bacteria and protozoan (oo)cysts in water: a review. Water Research. 40, pp. 3-22.

Hill, V.R., Kahler, A.M., Jothikumar, N., Johnson, T.B., Hahn, D. and Cromeans, T.L. (2007). Multistate evaluation of an ultrafiltration-based procedure for simultaneous recovery of enteric microbes in 100-liter tap water samples. Appl Environ Microbiol. 73, pp. 4218-25. doi: 10.1128/AEM.02713-06.

Hill, V.R., Polaczyk, A.L., Hahn, D., Narayanan, J., Cromeans, T.L., Roberts, J.M. et al. (2005). Development of a rapid method for simultaneous recovery of diverse microbes in drinking water by ultrafiltration with sodium polyphosphate and surfactants. Applied and Environmental Microbiology. 71, pp. 6878-84. doi: 10.1128/AEM.71.11.6878-6884.2005.

Hot, D., Legeay, O., Jacques, J., Gantzer, C., Caudrelier, Y., Guyard, K. et al. (2003). Detection of somatic phages, infectious enteroviruses and enterovirus genomes as indicators of human enteric viral pollution in surface water. Water Research. 37, pp. 4703-10. doi: 10.1016/S0043-1354(03)00439-1.

Hovi, T., Roivainen, M. and Blomqvist, S. (2007). Enterovirus with special reference to poliovirus and poliomyelitis eradication. Elsevier. pp. 69-89.

Hovi, T., Shulman, L.M., van der Avoort, H., Deshpande, J., Roivainen, M. and EM, D.E.Gourvil (2012). Role of environmental poliovirus surveillance in global polio eradication and beyond. Epidemiology and Infection. 140, pp. 1-13. doi: S095026881000316X [pii] 10.1017/S095026881000316X.

Hovi, T., Stenvik, M., Partanen, H. and Kangas, A. (2001). Poliovirus surveillance by examining sewage specimens. Quantitative recovery of virus after introduction into sewerage at remote upstream location. Epidemiology and Infection. 127, pp. 101-6.

Huang, W.C., Shih, W.L., Yang, S.C., Yen, T.Y., Lee, J.T., Huang, Y.C. et al. (2014). Predicting severe enterovirus 71 infection: Age, comorbidity, and parental behavior matter. J Microbiol Immunol Infect.

Hurst, C.J. (1988). Influence of aerobic microorganisms upon virus survival in soil. Canadian Journal of Microbiology. 34, pp. 696-9.

Hurst, C.J. and Adcock, N.J. (2000). Relationship between humans and their viruses. Viral Ecology. (Hurst, C.J., ed.). Academic Press. San Diego, CA. pp. 520-549.

Hurst, C.J., Gerba, C.P. and Cech, I. (1980). Effects of environmental variables and soil characteristics on virus survival in soil. Applied and Environmental Microbiology. 40, pp. 1067-79.

Hurst, C.J. and Murphy, P.A. (1996). The transmission and prevention of infectious disease. Modeling disease transmission and its prevention by disinfection. (Hurst, C.J., ed.). Cambridge University Press. pp. 3-54.

Hurst, C.J. (1988). Fate of viruses during waste-water sludge treatment processes. Critical Reviews in Environmental Control. 18, pp. 317-345.

Husman, A.M. de Roda and Bartram, J. (2007). Global supply of virus safe drinking-water. Human Viruses in Water, Perspectives in Medical Virology. (Bosch, A., ed.). Elsevier. Amsterdam, The Netherlands. pp. 127-162.

Ibrahim, W., Ouerdani, I., Pillet, S., Aouni, M., Pozzetto, B. and Harrath, R. (2014). Direct typing of human enteroviruses from wastewater samples. Journal of Virological Methods. 207, pp. 215-9. doi: 10.1016/j.jviromet.2014.07.018. 
Ikner, L.A., Soto-Beltran, M. and Bright, K.R. (2011). New method using a positively charged microporous filter and ultrafiltration for concentration of viruses from tap water. Applied and Environmental Microbiology. 77, pp. 3500-6. doi: 10.1128/AEM.02705-10.

Imamura, T. and Oshitani, H. (2015). Global reemergence of enterovirus D68 as an important pathogen for acute respiratory infections. Reviews in Medical Virology. 25, pp. 102-114.

International Life Sciences Institute (ILSI) (2000). Revised Framework for Microbial Risk Assessment. Water- and Foodborne Pathogen Risk Assessment Workshop, May 11.12, 1999. International Life Science Institute https://www.google.co.il/url?sa=t\&amp;rct=j\&amp;q=\&amp;esrc=s\&amp;source=web\&amp;cd=1\&amp;ved=0CB0QFjAA ahUKEwiDvdCP6YLIAhULPxQKHY-jAsY\&amp;url=http\%3A\%2F\%2Fwww.epa.gov\%2Fraf\%2Ffiles\%2FILSI-RA-Framework. pdf\&amp;usg=AFQjCNHB8OFSovaGsoWlNpuJRTENYmaGxA\&amp;b.

Jacangelo, J.G. and Trussell, R.R. (2002). International report: Water and wastewater disinfection: Trends, issues and practices. Water Science and Technology: Water Supply. 2, pp. 147-157.

Jacobs, S.E., Lamson, D.M., St George, K. and Walsh, T.J. (2013). Human rhinoviruses. Clin Microbiol Rev. 26 , pp. 135-62. doi: 10.1128/CMR.00077-12.

Jin, M., Shan, J., Chen, Z., Guo, X., Shen, Z., Qiu, Z. et al. (2013). Chlorine dioxide inactivation of enterovirus 71 in water and its impact on genomic targets. Environmental Science and Technology. 47, pp. 4590-7. doi: 10.1021/es305282g.

John, D.E. and Rose, J.B. (2005). Review of factors affecting microbial survival in groundwater. Environmental Science and Technology. 1, pp. 7345-7356.

Johnson, D.C., Enriquez, C.E., Pepper, I.L., Davis, T.L., Gerba, C.P. and Rose, J.B. (1997). Survival of Giardia, Cryptosporidium, poliovirus, and Salmonella in marine waters. Water Science and Technology. 35, pp. 261-268.

Jones, M.S., Lukashov, V.V., Ganac, R.D. and Schnurr, D.P. (2007). Discovery of a novel human picornavirus in a stool sample from a pediatric patient presenting with fever of unknown origin. Journal of Clinical Microbiology. 45, pp. 2144-50. doi: 10.1128/JCM.00174-07.

Joo, S.H., F. Monaco, D., Antmann, E. and Chorath, P. (2015). Sustainable approaches for minimizing biosolids production and maximizing reuse options in sludge management: A review. J Environ Manage. 158, pp. 133-45. doi: 10.1016/j.jenvman.2015.05.014.

Jung, J.Hee, Yoo, C.Hoon, Koo, E.Seo, Kim, H.Min, Na, Y., Jheong, W.H. et al. (2011). Occurrence of norovirus and other enteric viruses in untreated groundwaters of Korea. Journal of Water and Health. 9, pp. 544-55. doi: 10.2166/wh.2011.142.

Kapoor, A., Victoria, J., Simmonds, P., Slikas, E., Chieochansin, T., Naeem, A. et al. (2008). A highly prevalent and genetically diversified Picornaviridae genus in South Asian children. Proc Natl Acad Sci U S A. 105, pp. 20482-7. doi: 10.1073/pnas.0807979105.

Kargar, M., Sadeghipour, S. and Nategh, R. (2009). Environmental surveillance of non-polio enteroviruses in Iran. Virology Journal. 6, doi: 10.1186/1743-422x-6-149.

Karim, M.R., Glenn, E.P. and Gerba, C.P. (2008). The effect of wetland vegetation on the survival of Escherichia coli, Salmonella typhimurium, bacteriophage MS-2 and polio virus. Journal of Water and Health. 6, pp. 167-75. doi: 10.2166/wh.2008.024.

Karim, M.R., Rhodes, E.R., Brinkman, N., Wymer, L. and Fout, G.S. (2009). New electropositive filter for concentrating enteroviruses and noroviruses from large volumes of water. Applied and Environmental Microbiology. 75, pp. 2393-9. doi: 10.1128/AEM.00922-08.

Katayama, H., Haramoto, E., Oguma, K., Yamashita, H., Tajima, A., Nakajima, H. et al. (2008). One-year monthly quantitative survey of noroviruses, enteroviruses, and adenoviruses in wastewater collected from six plants in Japan. Water Research. 42, pp. 1441-8. 
Katayama, H., Okuma, K., Furumai, H. and Ohgaki, S. (2004). Series of surveys for enteric viruses and indicator organisms in Tokyo Bay after an event of combined sewer overflow. Water Sci Technol. 50, pp. 259-62.

Katayama, H., Shimasaki, A. and Ohgaki, S. (2002). Development of a virus concentration method and its application to detection of enterovirus and norwalk virus from coastal seawater. Appl Environ Microbiol. 68, pp. 1033-9.

Katzenelson, E. and Biedermann, N. (1976). Disinfection of Viruses in Sewage by Ozone. Water Res. 10, pp. 629-31.

Katzenelson, E., Koerner, G., Biedermann, N., Peleg, M. and Shuval, H.I. (1979). Measurement of the inactivation kinetics of poliovirus by ozone in a fast-flow mixer. Applied and Environmental Microbiology. 37, pp. 715-8.

Keswick, B.H., Wang, D.-.S. and Gerba, C.P. (1982). The Use of Microorganisms as Groundwater Tracers: A review. Groundwater. 20, pp. 142-149.

Kew, O.M., Cochi, S.L., Jafari, H.S., Wassilak, S.G.F., Mast, E.E., Diop, O.M. et al. (2014). Possible Eradication of Wild Poliovirus Type 3 - Worldwide, 2012. MMWR. Morbidity Mortality Weekly Report. 63, pp. 1031-1033.

Kew, O.M., Mulders, M.N., Lipskaya, G.Y., de Silva, E. and Pallansch, M.A. (1995). Molecular Epidemiology of Polioviruses. Seminars in Virology. 6, pp. 401-405.

Kew, O.M., Sutter, R.W., de Gourville, E.M., Dowdle, W.R. and Pallansch, M.A. (2005). Vaccine-derived polioviruses and the endgame strategy for global polio eradication. Annual Review of Microbiology. 59, pp. 587-635. doi: 10.1146/annurev.micro.58.030603.123625.

Khan, F. (2015). Enterovirus D68: acute respiratory illness and the 2014 outbreak. Emergency Medicine Clinics of North America. 33, pp. e19-32.

Khetsuriani, N., LaMonte-Fowlkes, A., Oberst, S. and Pallansch, M.A. (2006). Enterovirus surveillance-United States, 1970-2005. MMWR. Morbidity Mortality Weekly Report. Surveillance Summaries. 55, pp. 1-20.

Kitajima, M., Iker, B.C., Pepper, I.L. and Gerba, C.P. (2014). Relative abundance and treatment reduction of viruses during wastewater treatment processes-identification of potential viral indicators. The Science of the Total Environment. 488, pp. 290-296.

Kitajima, M. and Gerba, C.P. (2015). Aichi virus 1: environmental occurrence and behavior. Pathogens. 4, pp. 256-68. doi: 10.3390/pathogens4020256.

Kitajima, M., Iker, B.C., Rachmadi, A.T., Haramoto, E. and Gerba, C.P. (2014). Quantification and genetic analysis of salivirus/klassevirus in wastewater in Arizona, USA. Food and Environmental Virology. 6, pp. 213-6. doi: 10.1007/s12560-014-9148-2.

Kitajima, M., Rachmadi, A.T., Iker, B.C., Haramoto, E., Pepper, I.L. and Gerba, C.P. (2015). Occurrence and genetic diversity of human cosavirus in influent and effluent of wastewater treatment plants in Arizona, United States. Arch Virol. 160, pp. 1775-9. doi: 10.1007/s00705-015-2435-x.

Klement, C., Kissova, R., Lengyelova, V., Stipalova, D., Sobotova, Z., Galama, J.M.D. et al. (2013). Human enterovirus surveillance in the Slovak Republic from 2001 to 2011. Epidemiology and Infection. 141, pp. 2658-2662. doi: $10.1017 /$ s0950268813000563.

Kott, Y. and Vinokur, L. (1978). Coliphages survival as viral indicator in various wastewater quality effluents. Progress in Water Technology. 10, pp. 337-346.

Kroneman, A., Vennema, H., Deforche, K., Avoort, H.v d, Penaranda, S., Oberste, M.S. et al. (2011). An automated genotyping tool for enteroviruses and noroviruses. Journal of Clinical Virology. 51, pp. 121-5. doi: 10.1016/j.jcv.2011.03.006.

Kumar, S. (2011). Composting of municipal solid waste. Crit Rev Biotechnol. 31, pp. 112-36. doi: 10.3109/07388551.2010.492207. 
Kurosaki, Y., Abe, H., Morioka, H., Hirayama, J., Ikebuchi, K., Kamo, N. et al. (2003). Pyrimidine dimer formation and oxidative damage in M13 bacteriophage inactivation by ultraviolet C irradiation. Photochemistry and Photobiology. 78, pp. 349-54.

Lang, M., Mirand, A., Savy, N., Henquell, C., Maridet, S., Perignon, R. et al. (2014). Acute flaccid paralysis following enterovirus D68 associated pneumonia, France, 2014. 19, doi: http://dxdoiorg/102807/1560-7917ES2014194420952.

La Rosa, G., Pourshaban, M., Iaconelli, M. and Muscillo, M. (2010). Quantitative real-time PCR of enteric viruses in influent and effluent samples from wastewater treatment plants in Italy. Annali dell'Istituto Superiore di Sanita. 46, pp. 266-73. doi: Doi: 10.4415/ann_10_03_07.

Lee, S.H. and Kim, S.J. (2002). Detection of infectious enteroviruses and adenoviruses in tap water in urban areas in Korea. Water Research. 36, pp. 248-56.

Lee, S.H., Lee, C., Lee, K.W., Cho, H.B. and Kim, S.J. (2005). The simultaneous detection of both enteroviruses and adenoviruses in environmental water samples including tap water with an integrated cell culture-multiplex-nested PCR procedure. Journal of Applied Microbiology. 98, pp. 1020-9. doi: 10.1111/j.1365-2672.2004.02496.x.

Le Guyader, F., Haugarreau, L., Miossec, L., Dubois, E. and Pommepuy, M. (2000). Three-year study to assess human enteric viruses in shellfish. Applied and Environmental Microbiology. 66, pp. 3241-3248.

Leland, D.S. and Ginocchio, C.C. (2007). Role of cell culture for virus detection in the age of technology. Clinical Microbiology Reviews. 20, pp. 49-78. doi: 10.1128/CMR.00002-06.

Liang, Z. and Wang, J. (2014). EV71 vaccine, an invaluable gift for children. Clinical and Translational Immunology. 3, pp. e28. doi: 10.1038/cti.2014.24.

Li, D., Shi, H.C. and Jiang, S.C. (2010). Concentration of viruses from environmental waters using nanoalumina fiber filters. Journal of Microbiological Methods. 81, pp. 33-38. doi: 10.1016/j.mimet.2010.01.018.

Lipp, E.K., Farrah, S.A. and Rose, J.B. (2001). Assessment and impact of microbial fecal pollution and human enteric pathogens in a coastal community. Marine Pollution Bulletin. 42, pp. 286-293. doi: 10.1016/s0025-326x(00)00152-1.

Lipp, E.K., Kurz, R., Vincent, R., Rodriguez-Palacios, C., Farrah, S.R. and Rose, J.B. (2001). The effects of seasonal variability and weather on microbial fecal pollution and enteric pathogens in a subtropical estuary. Estuaries. 24 , pp. 266-276.

Lipp, E.K., Lukasik, J. and Rose, J.B. (2001). Human enteric viruses and parasites in the marine environment. Methods in Microbiology. 30, pp. 559-588.

Liu, P., Hill, V.R., Hahn, D., Johnson, T.B., Pan, Y., Jothikumar, N. et al. (2012). Hollow-fiber ultrafiltration for simultaneous recovery of viruses, bacteria and parasites from reclaimed water. Journal of Microbiological Methods. 88, pp. 155-61. doi: 10.1016/j.mimet.2011.11.007.

Locas, A., Martinez, V. and Payment, P. (2010). Removal of human enteric viruses and indicator microorganisms from domestic wastewater by aerated lagoons. Canadian Journal of Microbiology. 56, pp. 188-94. doi: 10.1139/w09-124.

Lodder, W.J. and De Roda Husman, A.M. (2005). Presence of noroviruses and other enteric viruses in sewage and surface waters in The Netherlands. Applied and Environmental Microbiology. 71, pp. 1453-61. doi: 10.1128/AEM.71.3.1453-1461.2005.

Lodder, W.J., Buisman, A.M., Rutjes, S.A., Heijne, J.C., Teunis, P.F. and De Roda Husman, A.M. (2012). Feasibility of quantitative environmental surveillance in poliovirus eradication strategies. Appl Environ Microbiol. 78, pp. 3800-5. doi: AEM.07972-11 [pii] 10.1128/AEM.07972-11.

Lu, S. (2014). EV71 vaccines: a milestone in the history of global vaccine development. Emerging microbes and infections.

3, pp. e27. doi: 10.1038/emi.2014.29. 
Lusk, M., Toor, G.S. and Obreza, T. (2014). Onsite Sewage Treatment and Disposal Systems: Viruses. Series of the Soil and Water Science Department, UF/IFAS Extension.

Magri, M.E., Philippi, L.S. and Vinneras, B. (2013). Inactivation of pathogens in feces by desiccation and urea treatment for application in urine-diverting dry toilets. Applied and Environmental Microbiology. 79, pp. 2156-63. doi: 10.1128/AEM.03920-12.

Manor, Y., Blomqvist, S., Sofer, D., Alfandari, J., Halmut, T., Abramovitz, B. et al. (2007). Advanced environmental surveillance and molecular analyses indicate separate importations rather than endemic circulation of wild type 1 poliovirus in Gaza district in 2002. Applied and Environmental Microbiology. 73, pp. 5954-8. doi: AEM.02537-06 [pii] 10.1128/AEM.02537-06.

Manor, Y., Handsher, R., Halmut, T., Neuman, M., Bobrov, A., Rudich, H. et al. (1999). Detection of poliovirus circulation by environmental surveillance in the absence of clinical cases in Israel and the Palestinian authority. J Clin Microbiol. 37, pp. 1670-5.

Manor, Y., Shulman, L.M., Kaliner, E., Hindiyeh, M., Ram, D., Sofer, D. et al. (2014). Intensified environmental surveillance supporting the response to wild poliovirus type 1 silent circulation in Israel, 2013. Euro Surveill. 19, pp. 20708. doi: 20708 [pii].

Mateu, M.G. (2011). Virus engineering: functionalization and stabilization. Protein Engineering, Design and Selection. 24, pp. 53-63. doi: 10.1093/protein/gzq069.

Mattle, M.J., Crouzy, B., Brennecke, M., Wigginton, K.R., Perona, P. and Kohn, T. (2011). Impact of virus aggregation on inactivation by peracetic acid and implications for other disinfectants. Environ Sci Technol. 45, pp. 7710-7. doi: 10.1021/es201633s.

Mayer, B.K., Ryu, H. and Abbaszadegan, M. (2008). Treatability of US Environmental Protection Agency contaminant candidate list viruses: removal of coxsackievirus and echovirus using enhanced coagulation. Environmental Science and Technology. 42, pp. 6890-6896.

McCaustland, K.A., Bond, W.W., Bradley, D.W., Ebert, J.W. and Maynard, J.E. (1982). Survival of hepatitis A virus in feces after drying and storage for 1 month. J Clin Microbiol. 16, pp. 957-8.

Melnick, J.L. and Rennick, V. (1980). Infectivity titers of enterovirus as found in human stools. J Med Virol. 5, pp. 205-20.

Mena, K.D. (2007). Waterborne Viruses: Assessing the Risks. Human Viruses in Water. 17, pp. 163-175.

Mesquita, J.R., Vaz, L., Cerqueira, S., Castilho, F., Santos, R., Monteiro, S. et al. (2011). Norovirus, hepatitis A virus and enterovirus presence in shellfish from high quality harvesting areas in Portugal. Food Microbiology. 28, pp. 936-941.

Mezzanotte, V., Antonelli, M., Citterio, S. and Nurizzo, C. (2007). Wastewater disinfection alternatives: chlorine, ozone, peracetic acid, and UV light. Water Environmental Research. 79, pp. 2373-9.

Michen, B. and Graule, T. (2010). Isoelectric points of viruses. Journal of Applied Microbiology. 109, pp. 388-97. doi: 10.1111/j.1365-2672.2010.04663.x.

Midgley, C.M., Jackson, M.A., Selvarangan, R., Turabelidze, G., Obringer, E., Johnson, D. et al. (2014). Severe respiratory illness associated with enterovirus D68 - Missouri and Illinois, 2014. MMWR. 63, pp. 798-799.

Milhano, N., Bragstad, K., Pfeiffer, H.C., Vainio, K., Bjornholt, J., Kran, A.M.B. et al. (2015). Acute flaccid paralysis surveillance system in Norway detected two cases of enterovirus D68 infection. Journal of Clinical Virology. 70, pp. S59-S60.

Minor, P.D. (1992). The molecular biology of poliovaccines. J Gen Virol. 73 ( Pt 12), pp. 3065-77.

MMWR, T. (2001). Apparent global interruption of wild poliovirus type 2 trasmission. MMWR. Morbidity Mortality Weekly Report. 50, pp. 222-224. 
Mocé-Llivina, L., Lucena, F. and Jofre, J. (2005). Enteroviruses and bacteriophages in bathing waters. Applied and Environmental Microbiology. 71, pp. 6838-44. doi: 10.1128/AEM.71.11.6838-6844.2005.

Momou, K.J., Akoua-Koffi, C. and Dosso, M. (2014). Detection of Enteroviruses in Water Samples from Yopougon, Cte d'Ivoire by Cell Culture and Polymerase Chain Reaction. Food and Environmental Virology. 6, pp. 23-30. doi: 10.1007/s12560-013-9130-4.

Monpoeho, S., Maul, A., Bonnin, C., Patria, L., Ranarijaona, S., Billaudel, S. et al. (2004). Clearance of human-pathogenic viruses from sludge: study of four stabilization processes by real-time reverse transcription-PCR and cell culture. Applied and Environmental Microbiology. 70, pp. 5434-40. doi: 10.1128/AEM.70.9.5434-5440.2004.

Monpoeho, S., Maul, A., Mignotte-Cadiergues, B., Schwartzbrod, L., Billaudel, S. and Ferre, V. (2001). Best viral elution method available for quantification of enteroviruses in sludge by both cell culture and reverse transcription-PCR. Applied and Environmental Microbiology. 67, pp. 2484-8. doi: 10.1128/AEM.67.6.2484-2488.2001.

Morales-Morales, H.A., Vidal, G., Olszewski, J., Rock, C.M., Dasgupta, D., Oshima, K.H. et al. (2003). Optimization of a reusable hollow-fiber ultrafilter for simultaneous concentration of enteric bacteria, protozoa, and viruses from water. Applied and Environmental Microbiology. 69, pp. 4098-102.

Morato, J., Mir, J., Codony, F., Mas, J. and Ribas, F. (2003). Microbial response to disinfectants. Handbook of 'Water and Wastewater Microbiology. (Mara, D. and Horan, N.J., ed.). Elsivier Academic Press. California.

Mudhoo, A. and Sharma., S.K. (2011). Microwave Irradiation Technology In Waste Sludge And Wastewater Treatment Research. Critical Reviews in Environmental Science and Technology. 41, pp. 999-1066.

National Research Council (2004). Indicators for waterborne pathogens. National Academies Press.

National Research Council,. (2002). Biosolids Applied To Land: Advancing Standards And Practices. National Academy Press. Washington D.C.

Ng, T.F., Marine, R., Wang, C., Simmonds, P., Kapusinszky, B., Bodhidatta, L. et al. (2012). High variety of known and new RNA and DNA viruses of diverse origins in untreated sewage. J Virol. 86, pp. 12161-75. doi: 10.1128/JVI.00869-12.

Ngwenya, N., Ncube, E.J. and Parsons, J. (2013). Recent advances in drinking water disinfection: successes and challenges. Rev Environ Contam Toxicol. 222, pp. 111-170.

Nix, W.A., Oberste, M.S. and Pallansch, M.A. (2006). Sensitive, seminested PCR amplification of VP1 sequences for direct identification of all enterovirus serotypes from original clinical specimens. Journal of Clinical Microbiology. 44, pp. 2698-704. doi: 10.1128/JCM.00542-06.

Nocker, A. and Gerba, C. (2010). Waterborne Pathogens Enterovirus. http://waterbornepathogens.susana.org/menuviruses Last accessed July 2015.

Nuanualsuwan, S. and Cliver, D.O. (2003). Infectivity of RNA from inactivated poliovirus. Appl Environ Microbiol. 69, pp. 1629-32.

Oberste, M.S., Maher, K., Kilpatrick, D.R., Flemister, M.R., Brown, B.A. and Pallansch, M.A. (1999). Typing of human enteroviruses by partial sequencing of VP1. Journal of Clinical Microbiology. 37, pp. 1288-93.

Oberste, M.S., Maher, K., Williams, A.J., Dybdahl-Sissoko, N., Brown, B.A., Gookin, M.S. et al. (2006). Species-specific RTPCR amplification of human enteroviruses: a tool for rapid species identification of uncharacterized enteroviruses. J Gen Virol. 87, pp. 119-28. doi: 10.1099/vir.0.81179-0.

Oberste, M.S., Nix, W.A., Maher, K. and Pallansch, M.A. (2003). Improved molecular identification of enteroviruses by RTPCR and amplicon sequencing. Journal of Clinical Virology. 26, pp. 375-7.

Oberste, M.S., Maher, K., Schnurr, D., Flemister, M.R., Lovchik, J.C., Peters, H. et al. (2004). Enterovirus 68 is associated with respiratory illness and shares biological features with both the enteroviruses and the rhinoviruses. J Gen Virol. 85, pp. 
Okoh, A.I., Sibanda, T. and Gusha, S.S. (2010). Inadequately treated wastewater as a source of human enteric viruses in the environment. Int J Environ Res Public Health. 7, pp. 2620-37. doi: 10.3390/ijerph7062620.

Olszewski, J., Winona, L. and Oshima, K.H. (2005). Comparison of 2 ultrafiltration systems for the concentration of seeded viruses from environmental waters. Canadian Journal of Microbiology. 51, pp. 295-303. doi: 10.1139/w05-011.

Oragui, J.I., Curtis, T.P., Silva, S.A. and Mara, D.D. (1987). The removal of excreted bacteria and viruses in deep waste stabilization ponds. Water Science and Technology. 19, pp. 569-573.

Ottoson, J., Hansen, A., Bjorlenius, B., Norder, H. and Stenström, T.A. (2006). Removal of viruses, parasitic protozoa and microbial indicators in conventional and membrane processes in a wastewater pilot plant. Water Research. 40, pp. 1449-1457. doi: 10.1016/j.watres.2006.01.039.

Ottoson, J., Hansen, A., Westrell, T., Johansen, K., Norder, H. and Stenström, T.A. (2006). Removal of noro- and enteroviruses, Giardia cysts, Cryptosporidium oocysts, and fecal indicators at four secondary wastewater treatment plants in Sweden. Water Environmental Research. 78, pp. 828-34.

Pallansch, M., Oberste, M.S. and Whitton, J.L. (2013). Enteroviruses as agents of emerging infectious diseases. Fields Virology, Sixth Edition. (Knipe, D.M., Howley, P.M., I, C.J., Griffin, D.E., Lamb, R.A., Martin, M.A. et al., ed.). Wolters Klewer / Lippincott Williams \&amp; Wilkins. Philadelphia. pp. 490-530.

Parashar, U.D. and Glass, R.I. (2012). Chapter 190. Viral Gastroenteritis. Harrison's Principles of Internal Medicine. 18 ed. (Longo, D.L., Fauci, A.S., Kasper, D.L., Hauser, S.L., J. Jameson, L. and Loscalzo, J., ed.). McGraw-Hill. New York, NY, USA. pp. 1588-1592.

Parkin, R.T., Soller, J.A. and Olivieri, A.W. (2003). Incorporating susceptible subpopulations in microbial risk assessment: pediatric exposures to enteroviruses in river water. Journal of Exposure Analysis and Environmental Epidemiology. 13, pp. 161-8. doi: 10.1038/sj.jea.7500265.

Pavlov, D.N. (2006). Poliovirus vaccine strains in sewage and river water in South Africa. Canadian Journal of Microbiology. 52, pp. 717-723. doi: 10.1139/w06-026.

Pavlov, D.N., Van Zyl, W.B., Van Heerden, J., Grabow, W.O.K. and Ehlers, M.M. (2005). Prevalence of vaccine-derived polioviruses in sewage and river water in South Africa. Water Research. 39, pp. 3309-3319. doi: 10.1016/j.watres.2005.05.027.

Payment, P., Trudel, M. and Plante, R. (1985). Elimination of viruses and indicator bacteria at each step of treatment during preparation of drinking water at seven water treatment plants. Applied and Environmental Microbiology. 49, pp. 1418-1428.

Payment, P., Tremblay, M. and Trudel, M. (1985). Relative resistance to chlorine of poliovirus and coxsackievirus isolates from environmental sources and drinking water. Applied and Environmental Microbiology. 49, pp. 981-3.

Pellegrin, M.L., Greiner, A.D., Diamond, J., Aguinaldo, J., Padhye, L., Arabi, S. et al. (2011). Membrane Processes. Water Environment

R e s e a r c h https://www.google.co.il/url?sa=t\&amp;rct=j\&amp;q=\&amp;esrc=s\&amp;source=web\&amp;cd=1\&amp;ved=0CB0QFjAA ahUKEwi1qp7_9JPHAhXiF9sKHXIOB4E\&amp;url=http\%3A\%2F\%2Fwww.ingentaconnect.com\%2Fcontent\%2Fwef\%2Fwer \%2F2011\%2F00000083\%2F00000010\%2Fart00008\%3Fcrawler\%3Dtru. doi: 10.2175/106143011X13075599869290.

Pianetti, A., Citterio, B., Sabatini, L., Pierfelici, L., Colantoni, P. and Bruscolini, F. (2007). Techniques for the recovery of enteric viruses from artificially contaminated marine sediments. Igiene e Sanita Pubblica. 63, pp. 419-31.

Pickering, A.J., Julian, T.R., Marks, S.J., Mattioli, M.C., Boehm, A.B., Schwab, K.J. et al. (2012). Fecal contamination and diarrheal pathogens on surfaces and in soils among Tanzanian households with and without improved sanitation. Environmental Science and Technology. 46, pp. 5736-43. doi: 10.1021/es300022c. 
Plotkin, S.A. and Vidor, E. (2008). Poliovirus vaccine - inactivated. Vaccines, Fifth Edition. (Plotkin, S.A., Orenstein, W.A. and Offit, P.A., ed.). Saunders/Elsevier. Philadelphia, Pa. pp. 605-629.

Polaczyk, A.L., Narayanan, J., Cromeans, T.L., Hahn, D., Roberts, J.M., Amburgey, J.E. et al. (2008). Ultrafiltration-based techniques for rapid and simultaneous concentration of multiple microbe classes from 100-L tap water samples. Journal of Microbiological Methods. 73, pp. 92-9. doi: 10.1016/j.mimet.2008.02.014.

Popat, S.C., Yates, M.V. and Deshusses, M.A. (2010). Kinetics of inactivation of indicator pathogens during thermophilic anaerobic digestion. Water Res. 44, pp. 5965-72. doi: 10.1016/j.watres.2010.07.045.

Pourcher, A.M., Morand, P., Picard-Bonnaud, F., Billaudel, S., Monpoeho, S., Federighi, M. et al. (2005). Decrease of enteric micro-organisms from rural sewage sludge during their composting in straw mixture. Journal of Applied Microbiology. 99, pp. 528-539. doi: 10.1111/j.1365-2672.2005.02642.x.

Prim, N., Rodriguez, G., Margall, N., Del Cuerpo, M., Trallero, G. and Rabella, N. (2013). Combining cell lines to optimize isolation of human enterovirus from clinical specimens: report of 25 years of experience. Journal of Medical Virology. 85, pp. 116-20. doi: 10.1002/jmv.23426.

Pusch, D., Oh, D.Y., Wolf, S., Dumke, R., Schröter-Bobsin, U., Höhne, M. et al. (2005). Detection of enteric viruses and bacterial indicators in German environmental waters. Archives of Virology. 150, pp. 929-947.

Qiu, Y., Lee, B.E., Newmann, N., Ashbolt, N., Craik, S., Maal-Bared, R. et al. (2015). Assessment of human virus removal during municipal wastewater treatment in Edmonton, Canada. Journal of Applied Microbiology. 119, pp. 1729-1739.

Qu, X., Alvarez, P.J. and Li, Q. (2013). Applications of nanotechnology in water and wastewater treatment. Water Res. 47, pp. 3931-46. doi: 10.1016/j.watres.2012.09.058.

Racaniello, V.R. (2013). Picornaviridae: The viruses and replication. Fields Virology, Sixth Edition. (Knipe, D.M., Howley, P.M., I, C.J., Griffin, D.E., Lamb, R.A., Martin, M.A. et al., ed.). Wolters Klewer / Lippincott Williams \&amp; Wilkins. Philadelphia.

Rachmadi, A.T., Kitajima, M., Pepper, I.L. and Gerba, C.P. (2016). Enteric and indicator virus removal by surface flow wetlands. The Science of the Total Environment. 542, pp. 976-82.

Rajal, V.B., McSwain, B.S., Thompson, D.E., Leutenegger, C.M., Kildare, B.J. and Wuertz, S. (2007). Validation of hollow fiber ultrafiltration and real-time PCR using bacteriophage PP7 as surrogate for the quantification of viruses from water samples. Water Res. 41, pp. 1411-22. doi: 10.1016/j.watres.2006.12.034.

Rao, V.C., Metcalf, T.G. and Melnick, J.L. (1986). Human viruses in sediments, sludges, and soils. Bulletin of the World Health Organization. 64, pp. 1-13.

Reynolds, K.A. (2004). Integrated cell culture/PCR for detection of enteric viruses in environmental samples. Methods in Molecular Biology. 268, pp. 69-78. doi: 10.1385/1-59259-766-1:069.

Reynolds, K.A., Gerba, C.P. and Pepper, I.L. (1996). Detection of infectious enteroviruses by an integrated cell culture-PCR procedure. Applied and Environmental Microbiology. 62, pp. 1424-7.

Rhoades, R.E., Tabor-Godwin, J.M., Tsueng, G. and Feuer, R. (2011). Enterovirus infections of the central nervous system. Virology. 411, pp. 288-305. doi: 10.1016/j.virol.2010.12.014.

Rhodes, E.R., Hamilton, D.W., See, M.J. and Wymer, L. (2011). Evaluation of hollow-fiber ultrafiltration primary concentration of pathogens and secondary concentration of viruses from water. Journal of Virological Methods. 176, pp. 38-45. doi: 10.1016/j.jviromet.2011.05.031.

Rieck, C., von Münch, E. and Hoffmann, H. (2012). Technology Review of Urine-diverting dry toilets (UDDTs) - Overview of design, operation, management and costs. Deutsche Gesellschaft für Internationale Zusammenarbeit (GIZ) GmbH. (http://www.susana.org/en/resources/library/details/874 , Last accessed July 2015. pp. 1-52. 
Robinson, C.M., Jesudhasan, P.R. and Pfeiffer, J.K. (2014). Bacterial lipopolysaccharide binding enhances virion stability and promotes environmental fitness of an enteric virus. Cell Host and Microbe. 15, pp. 36-46. doi: 10.1016/j.chom.2013.12.004.

Rock, C.M., Gerba, C.P. and Pepper, I.L. (2015). Chapter 27 Recycled Water Treatment and Reuse. Environmental Microbiology. Third Edition. (Pepper, I.L., Gerba, C.P. and Gentry, T.J., ed.). Elsevier Inc. San Diego, CA. USA. pp. 623-632.

Rodríguez-Díaz, J., Querales, L., Caraballo, L., Vizzi, E., Liprandi, F., Takiff, H. et al. (2009). Detection and characterization of waterborne gastroenteritis viruses in urban sewage and sewage-polluted river waters in Caracas, Venezuela. Applied and Environmental Microbiology. 75, pp. 387-394. doi: 10.1128/AEM.02045-08.

Rodriguez, R.A., Thie, L., Gibbons, C.D. and Sobsey, M.D. (2012). Reducing the effects of environmental inhibition in quantitative real-time PCR detection of adenovirus and norovirus in recreational seawaters. Journal of Virological Methods. 181, pp. 43-50. doi: 10.1016/j.jviromet.2012.01.009.

Rose, J.B., Farrah, S.R., Harwood, V.J., Levine, A., Lukasik, J., Menendez, P. et al. (2004). Reduction of pathogens, indicator bacteria, and alternative indicators by wastewater treatment and reclamation processes. Water Science and Technology: Water Supply. Water Environmental Research Foundation (WERF), Final Report No. 00-PUM-2T.

Rose, M.A., Dhar, A.K., Brooks, H.A., Zecchini, F. and Gersberg, R.M. (2006). Quantitation of hepatitis A virus and enterovirus levels in the lagoon canals and Lido beach of Venice, Italy, using real-time RT-PCR. Water Research. 40, pp. 2387-2396. doi: 10.1016/j.watres.2006.03.030.

Rossi, S., Antonelli, M., Mezzanotte, V. and Nurizzo, C. (2007). Peracetic acid disinfection: a feasible alternative to wastewater chlorination. Water Environmental Research. 79, pp. 341-50.

Roy, D., Wong, P.K., Engelbrecht, R.S. and Chian, E.S. (1981). Mechanism of enteroviral inactivation by ozone. Applied and Environmental Microbiology. 41, pp. 718-23.

Roy, S.L., Scallan, E. and Beach, M.J. (2006). The rate of acute gastrointestinal illness in developed countries. Journal of Water and Health. 4 Suppl 2, pp. 31-69.

Ryu, W.S., Hong, J., Hwang, S., Kim, A., Kim, J. and Cheon, D.S. (2010). Enterovirus 71 infection with central nervous system involvement, South Korea. Emerging Infectious Diseases. 16, pp. 1764-1766.

Rzezutka, A. and Carducci, A. (2013). Sampling strategies for virus detection in foods, food-processing environments, water and air. Viruses in Food and Water. (Cook, N., ed.). Elsevier, Woodhead Publishing.

Rzezutka, A. and Cook, N. (2004). Survival of human enteric viruses in the environment and food. FEMS Microbiology Reviews. 28, pp. 441-53. doi: 10.1016/j.femsre.2004.02.001 S0168644504000154 [pii].

Sagik, B.P., Moore, B.E. and Sorber, C.A. (1980). Human enteric virus survival in soil following irrigation with sewage plant effluents. Research Reporting Series 1, Environmental Health Effects Research. Health Effects Research Laboratory, Office of Research and Development Available to the public through the National Technical Information Service. Cincinnati, Ohio Springfield, Va. pp. xiii, 138 p.

Schaub, S.A., Kenyon, K.F., Bledsoe, B. and Thomas, R.E. (1980). Evaluation of the overland runoff mode of land wastewater treatment for virus removal. Applied and Environmental Microbiology. 39, pp. 127-34.

Schijven, J.F. and Hassanizadeh, S.M. (2010). Removal of Viruses by Soil Passage: Overview of Modeling, Processes, and Parameters. 30, http://dx.doi.org/10.1080/10643380091184174 Last accessed July 2015. pp. 49-127.

Schijven, J.F. and Hassanizadeh, M.S. (2000). Removal of viruses by soil passage: Overview of modeling, processes, and parameters. Critical Reviews in Environmental Science and Technology. 30, Taylor \&amp; Francis. pp. 49-127.

Schwartzbrod, L. and Mathieu, C. (1986). Virus recovery from wastewater treatment plant sludges. Water Res. 20, pp. 1011-1013. 
Sedmak, G., Bina, D., Macdonald, J. and Couillard, L. (2005). Nine-year study of the occurrence of culturable viruses in source water for two drinking water treatment plants and the influent and effluent of a Wastewater Treatment Plant in Milwaukee, Wisconsin (August 1994 through July 2003). Applied and Environmental Microbiology. 71, pp. 1042-50. doi: 10.1128/AEM.71.2.1042-1050.2005.

Shulman, L.M., Manor, Y., Sofer, D. and Mendelson, E. (2012). Bioterrorism and Surveillance for Infectious Diseases Lessons from Poliovirus and Enteric Virus Surveillance. Journal of Bioterrorism and Biodefence. S4, doi: 10.4172/2157-2526.S4-004.

Shulman, L.M., Mendelson, E., Anis, E., Bassal, R., Gdalevich, M., Hindiyeh, M. et al. (2014). Laboratory challenges in response to silent introduction and sustained transmission of wild poliovirus type 1 in Israel during 2013. The Journal of Infectious Diseases. 210 Suppl 1, pp. S304-14. doi: 10.1093/infdis/jiu294 jiu294 [pii].

Shulman, L.M. (2012). Polio and its Epidemiology. Encyclopedia of Sustainability Science and Technology. (Meyers, R.A., ed.). Springer Science+Business Media, LLC. pp. 8123-8173.

Shulman, L.M., Martin, J., Sofer, D., Burns, C.C., Manor, Y., Hindiyeh, M. et al. (2015). Genetic analysis and characterization of wild poliovirus type 1 during sustained transmission in a population with $>95 \%$ vaccine coverage, Israel 2013. Clinical Infectious Diseases. 60, pp. 1057-1064. doi: 10.1093/cid/ciu1136.

Sidhu, J.P. and Toze, S.G. (2009). Human pathogens and their indicators in biosolids: a literature review. Environment International. 35, pp. 187-201.

Simmons, F.J. and Xagoraraki, I. (2011). Fate of Viruses in Wastewater Utilities. https://www.google.co.il/url?sa=t\&amp;rct=j\&amp;q=\&amp;esrc=s\&amp;source=web\&amp;cd=1\&amp;ved=0CBwQFjAA ahUKEwivuezH65PHAhXhI9sKHUrDCE8\&amp;url=http\%3A\%2F\%2Fwww.srcosmos.gr\%2Fsrcosmos\%2Fshowpub.aspx\%3 F a a \% $315183 \& a m p$; e i = J Q D D Ve - S G u H H 7 Ab Kh q P 4 B A \& $a m p$; u s g = AF Q j C N Ir 4 i O - Vt Fq1E3PH6kV4rgT3GCw\&amp; bvm=bv. pp. A-1741-1751.

Simmons, F.J. and Xagoraraki, I. (2011). Release of infectious human enteric viruses by full-scale wastewater utilities. Water Res. 45, pp. 3590-8. doi: 10.1016/j.watres.2011.04.001 S0043-1354(11)00176-X [pii].

Skraber, S., Gassilloud, B., Schwartzbrod, L. and Gantzer, C. (2004). Survival of infectious Poliovirus-1 in river water compared to the persistence of somatic coliphages, thermotolerant coliforms and Poliovirus-1 genome. Water Res. 38, pp. 2927-33. doi: 10.1016/j.watres.2004.03.041 S0043-1354(04)00190-3 [pii].

Skraber, S., Ogorzaly, L., Helmi, K., Maul, A., Hoffmann, L., Cauchie, H.M. et al. (2009). Occurrence and persistence of enteroviruses, noroviruses and F-specific RNA phages in natural wastewater biofilms. Water Res. 43, pp. 4780-9. doi: 10.1016/j.watres.2009.05.020.

Skraber, S., Schijven, J.F., Gantzer, C. and De Roda Husman, A.M. (2005). Pathogenic viruses in drinking-water biofilms: a public health risk?. Biofilms. 2, pp. 105-117.

Smith, E.M., Gerba, C.P. and Melnick, J.L. (1978). Role of sediment in the persistence of enteroviruses in the estuarine environment. Applied and Environmental Microbiology. 35, pp. 685-9.

Soares, A.C., Straub, T.M., Pepper, I.L. and Gerba, C.P. (1994). Effect of anaerobic digestion on the occurrence of enteroviruses and Giardia cysts in sewage sludge. Journal of Environmental Science and Health. Part A: Environmental Science and Engineering and Toxicology. 29, pp. 1887-1897.

Sobsey, M.D. and Meschke, J.S. (2003). Virus Survival In The Environment With Special Attention To Survival In Sewage Droplets And Other Environmental Media Of Fecal Or Respiratory Origin - Draft - August $21,2003$. http://www.unc.edu/courses/2008spring/envr/421/001/WHO_VirusSurvivalReport_21Aug2003.pdf Last accessed July 2015.

Soller, J.A. (2006). Use of microbial risk assessment to inform the national estimate of acute gastrointestinal illness attributable to microbes in drinking water. Journal of Water and Health. 4 Suppl 2, pp. 165-86. 
Song, Y.C., Kwon, S.J. and Woo, J.H. (2004). Mesophilic and thermophilic temperature co-phase anaerobic digestion compared with single-stage mesophilic- and thermophilic digestion of sewage sludge. Water Res. 38, pp. 1653-62. doi: 10.1016/j.watres.2003.12.019.

Speece, R.E., Boonyakitsombut, S., Kim, M., Azbar, N. and Ursillo, P. (2006). Overview of anaerobic treatment: thermophilic and propionate implications. Water Environmental Research. 78, pp. 460-73.

Sprenger, C., Lorenzen, G., Grunert, A., Ronghang, M., Dizer, H., Selinka, H.C. et al. (2014). Removal of indigenous coliphages and enteric viruses during riverbank filtration from highly polluted river water in Delhi (India). Journal of Water and Health. 12, pp. 332-42. doi: 10.2166/wh.2014.134.

Springthorpe, S. and Sattar, S.A. (2007). Virus removal during drinking water treatment. Human viruses in water, Perspectives in medical virology. (Bosch, A., ed.). Elsevier. Amsterdam. pp. 109-126.

Stellrecht, K.A., Lamson, D.M. and Romero, J.R. (2010). Enteroviruses and parechoviruses. Manual of Clinical Microbiology. (Versalovic, J., Carroll, K.C., Funke, G., Jorgensen, J.H., Landry, M.L. and Warnock, D.W., ed.). American Society for Microbiology. Washington, DC. pp. 1388-1399.

Stenström, T.A., Seidu, R., Ekane, N. and Zurbrügg, C. (2011). Microbial exposure and health assessments in sanitation technologies and systems. Stockholm Environment Institute (SEI) http://www.susana.org/_resources/documents/default/2-1236-microbialexposurehealthassessmentsinsanitationtechnologies systems.pdf Last accessed July 2015.

Stenström, T.A., Seidu, R., Ekane, N. and Zurbrügg, C. (2011). Microbial Exposure and Health Assessments in Sanitation Technologies and Systems. Sustainable Sanitation Alliance, EAWAG, Norwegian University of Life Sciences, Ecological Sanitation Research Programme. Stockholm, Sweden. pp. 1-165.

Stewart, J.R., Gast, R.J., Fujioka, R.S., Solo-Gabriele, H.M., Meschke, J.S., Amaral-Zettler, L.A. et al. (2008). The coastal environment and human health: microbial indicators, pathogens, sentinels and reservoirs. Environmental Health. 7 Suppl 2, pp. S3. doi: 10.1186/1476-069X-7-S2-S3.

Straub, T.M., Pepper, I.L. and Gerba, C.P. (1994). Detection of naturally occurring enteroviruses and hepatitis A virus in undigested and anaerobically digested sludge using the polymerase chain reaction. Canadian Journal of Microbiology. 40, pp. 884-8.

Sutter, R.W., Kew, O.M. and Cochi, S.L. (2008). Poliovirus vaccine - live. Vaccines, Fifth Edition. (Plotkin, S.A., Orenstein, W.A. and Offit, P.A., ed.). Saunders/Elsevier. Philadelphia, Pa. pp. 631-685.

Symonds, E.M. and Breibart, M. (2015). Affordable enteric virus detection techniques are needed to support changing paradigms in water quality management. Clean - Soil, Air, Water. 43, pp. 8-12.

Symonds, E.M., Griffin, D.W. and Breitbart, M. (2009). Eukaryotic viruses in wastewater samples from the United States. Applied and Environmental Microbiology. 75, pp. 1402-9. doi: 10.1128/AEM.01899-08.

Symonds, E.M., Verbyla, M.E., Lukasik, J.O., Kafle, R.C., Breitbart, M. and Mihelcic, J.R. (2014). A case study of enteric virus removal and insights into the associated risk of water reuse for two wastewater treatment pond systems in Bolivia. Water Research. 65, doi: 10.1016/j.watres.2014.07.032.

Tapparel, C., Siegrist, F., Petty, T.J. and Kaiser, L. (2013). Picornavirus and enterovirus diversity with associated human diseases. Infection, Genetics and Evolution. 14, pp. 282-93. doi: 10.1016/j.meegid.2012.10.016.

Templeton, M.R., Andrews, R.C. and Hofmann, R. (2008). Particle-Associated Viruses in Water: Impacts on Disinfection Processes. Critical Reviews in Environmental Science and Technology. 38, pp. 137-164. doi: 10.1080/10643380601174764.

Templeton, M.R., Andrews, R.C. and Hofmann, R. (2007). Removal of particle-associated bacteriophages by dual-media filtration at different filter cycle stages and impacts on subsequent UV disinfection. Water Res. 41, pp. 2393-406. doi: 10.1016/j.watres.2007.02.047. 
Templeton, M., Hofmann, R. and Andrews, R.C. (2004). Ultraviolet disinfection of particle-associated viruses. Chemical Water and Wastewater Treatment. (Hahn, H., Hoffman, E. and Odegaard, H., ed.). IWA Publishing. Padstow, Cornwall, UK. pp. 109-116.

Theron, J. and Cloete, T.E. (2002). Emerging waterborne infections: contributing factors, agents, and detection tools. Critical Reviews in Microbiology. 28, pp. 1-26. doi: 10.1080/1040-840291046669.

Theron, J., Walker, J.A. and Cloete, T.E. (2008). Nanotechnology and water treatment: applications and emerging opportunities. Critical Reviews in Microbiology. 34, pp. 43-69. doi: 10.1080/10408410701710442.

Tillett, T. (2013). Pit latrines and groundwater contamination: negative impacts of a popular sanitation method. Environmental Health Perspectives. 121, pp. a169. doi: 10.1289/ehp.121-a169.

USEPA (2013). Physical/Chemical Treatment Processes. https://www.google.co.il/url?sa=t\&amp;rct=j\&amp;q=\&amp;esrc=s\&amp;source=web\&amp;cd=1\&amp;ved=0CCAQFjAA ahUKEwjmzuSp3aTHAhVIuBoKHUabD1U\&amp;url=http\%3A\%2F\%2Fwater.epa.gov\%2Fscitech\%2Fwastetech\%2Fupload \%2FEmerging-Technologies-Report-2.pdf\&amp;ei=69rLVaatM8jwasa2vqgF\&amp;usg=AFQjCNEtShu.

USEPA (2006). Emerging Technologies for Biosolids Management EPA 832-R-06-005 September 2006. USEPA https://www.google.co.il/url?sa=t\&amp;rct=j\&amp;q=\&amp;esrc=s\&amp;source=web\&amp;cd=2\&amp;ved=0CCgQFjAB ahUKEwiek_y3h5HHAhWIltsKHROECkU\&amp;url=http\%3A\%2F\%2Fwater.epa.gov\%2Fscitech\%2Fwastetech\%2Fupload\% 2F2007_04_24_mtb_epa-biosolids.pdf\&amp;ei=uYrBVd7SBoit7gaTiKqoBA\&amp;usg=AFQjCNGyj-T.

USEPA (2002). Wastewater Technology Fact Sheet Aerated, Partial Mix Lagoons. USEPA https://www.google.co.il/url?sa=t\&amp;rct=j\&amp;q=\&amp;esrc=s\&amp;source=web\&amp;cd=2\&amp;ved=0CCcQFjAB a h U KEwiJ 1 I -

i7ofHAhVDqx4KHQoiDNg\&amp;url=http\%3A\%2F\%2Fwater.epa.gov\%2Fscitech\%2Fwastetech\%2Fupload\%2F2002_10_15_ mtb_apartlag.pdf\&amp;ei=Xri8VYmtLsPWeorEsMAN\&amp;usg=AFQjCNFnIJknNND6SU.

USEPA (2002). Wastewater Technology Fact Sheet Facultative Lagoons. USEPA.

USEPA (2000). Wastewater Technology Fact Sheet Oxidation Ditches. USEPA, https://www.google.co.il/url?sa=t\&amp;rct=j\&amp;q=\&amp;esrc=s\&amp;source=web\&amp;cd=1\&amp;ved=0CBwQFjAA ahUKEwi4yfT7_IHHAhXEbhQKHTLUAX8\&amp;url=http\%3A\%2F\%2Fwater.epa.gov\%2Fscitech\%2Fwastetech\%2Fupload\% 2F2002_06_28_mtb_oxidation_ditch.pdf\&amp;ei=eqK5VbikLMTdUbKoh_gH\&amp;usg=AFQjCNGgoE.

USEPA (1999). Water Efficiency Technology Fact Sheet Composting Toilets. USEPA, http://www.epa.gov/ow mitnet/m tbfact.htm

http://www.google.co.il/url?sa=t\&amp;rct=j\&amp;q=\&amp;esrc=s\&amp;source=web\&amp;cd=1\&amp;ved=0CB0QFjAA \&amp;url=http\%3A\%2F\%2Fwater.epa.gov\%2Faboutow\%2Fowm\%2Fupload\%2F2005_07_14_comp.pdf\&amp;ei=v3afVYjH BsWUUY_rt5AL\&amp;usg=AFQjCNFGKzl5e9nDMf8yn.

USEPA (1999). Wastewater Technology Fact Sheet Ozone Disinfection. USEPA EPA 832-F-99-063 September 1999.

USEPA (1999). Environmental Regulations and Technology. Control of Pathogens and Vector Attraction in Sewage Sludge. United States Environmental Protection Agency, Centre for Environmental Research. Ohio.

USEPA (1994). Land Application of Sewage Sludge - A Guide for Land Appliers on the Requirements of the Federal Standards for the Use or Disposal of Sewage Sludge, 40 CFR Part 503. USEPA EPA/831-B-93-002b; downloadable from EPA last accessed July 2015.

USEPA (1993). Constructed Wetlands for Wastewater Treatment and Wildlife Habitat. USEPA https://www.google.co.il/url?sa=t\&amp;rct=j\&amp; $\mathrm{q}=\& a m p ; \mathrm{esrc}=\mathrm{s} \& a m p ;$ source=web\&amp;cd=1\&amp;ved=0CCEQFjAA ahUKEwiuwP2K_oHHAhXHxRQKHYJJBcY\&amp;url=http\%3A\%2F\%2Fwww.epa.gov\%2Fowow\%2Fwetlands\%2Fpdf\%2FCon structedWetlands-Complete.pdf\&amp;ei=pqO5Va7VLseLU4KTlbAM\&amp;usg=AFQjCNH8C7tBjNYnJrOdJw.

USEPA (1991). Guidance Manual For Compliance With The Filtration And Disinfection Requirements For Public Water Systems Using Surface Water $\quad$ Sources. https://www.google.co.il/url?sa=t\&amp;rct=j\&amp;q=\&amp;esrc=s\&amp;source=web\&amp;cd=1\&amp;ved=0CB0QFjAA 
ahUKEwiAs6GR74nHAhXFa9sKHbKOD1Y\&amp;url=http\%3A\%2F\%2Fwater.epa.gov\%2Flawsregs\%2Frulesregs\%2Fsdwa\% 2Fswtr\%2Fupload\%2Fguidsws.pdf\&amp;ei=t8W9VcD7EsXX7Qaynb6wBQ\&amp;usg=AFQjCNEPDFchrAjUD.

USEPA (1988). Occurrence of pathogens in distribution and marketing municipal sludges EPA/600/S1-87/014. USEPA http://nepis.epa.gov/Exe/ZyNET.exe/2000TRVA.TXT?ZyActionD=ZyDocument\&amp;Client=EPA\&amp;Index=1986+Thru+ $1990 \& a m p ;$ Docs $=\& a m p ;$ Query $=\& a m p ;$ Time $=\& a m p ;$ EndTime $=\& a m p ;$ SearchMethod $=1 \& a m p ;$ TocRestrict $=$ n\& $a m p ;$ Toc $=\& a$

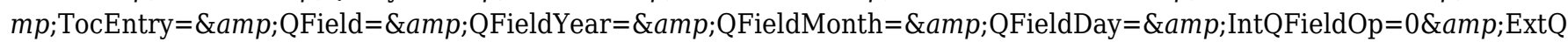
FieldOp=0\&amp;XmlQ.

USEPA (1981). Process Design Manual for Land Treatment of Municipal Wastewater EPA 625/1-81-013. USEPA.

Vasickova, P. and Kovarcik, K. (2013). Natural persistence of food and waterborne viruses. Viruses in Food and Water. (Cook, N., ed.). Elsevier, Woodhead Publishing. pp. 179-204.

Vasickova, P., Pavlik, I., Verani, M. and Carducci, A. (2010). Issues Concerning Survival of Viruwses on Surfaces. Food Environ. Virol. 2, pp. 24-34.

Verbyla, M.E. and Mihelcic, J.R. (2015). A review of virus removal in wastewater treatment pond systems. Water Research. 71, pp. 107-24.

Verheyen, J., Timmen-Wego, M., Laudien, R., Boussaad, I., Sen, S., Koc, A. et al. (2009). Detection of adenoviruses and rotaviruses in drinking water sources used in rural areas of Benin, West Africa. Applied and Environmental Microbiology. 75, pp. 2798-801.

Verma, K., Gupta, K.D. and Gupta, A.B. (2014). A review on sewage disinfection and need of improvement. Desalination and Water Treatment. pp. 1-5. doi: 10.1080/19443994.2014.967307.

Viau, E., Bibby, K., Paez-Rubio, T. and Peccia, J. (2011). Toward a consensus view on the infectious risks associated with land application of sewage sludge. Environmental Science and Technology. 45, pp. 5459-69. doi: 10.1021/es200566f.

Viau, E. and Peccia, J. (2009). Survey of wastewater indicators and human pathogen genomes in biosolids produced by class a and class B stabilization treatments. Applied and Environmental Microbiology. 75, pp. 164-74. doi: 10.1128/AEM.01331-08.

Vivier, J.C., Ehlers, M.M. and Grabow, W.O.K. (2004). Detection of enteroviruses in treated drinking water. Water Res. 38, pp. 2699-2705.

Wade, T.J., Sams, E., Brenner, K.P., Haugland, R., Chern, E., Beach, M. et al. (2010). Rapidly measured indicators of recreational water quality and swimming-associated illness at marine beaches: a prospective cohort study. Environmental Health : a Global Access Science Source. 9, pp. 66. doi: 10.1186/1476-069X-9-66.

Wang, X., Hu, X., Wang, H. and Hu, C. (2012). Synergistic effect of the sequential use of UV irradiation and chlorine to disinfect reclaimed water. Water Res. 46, pp. 1225-32. doi: 10.1016/j.watres.2011.12.027 S0043-1354(11)00799-8 [pii].

Wen, Q., Tutuka, C., Keegan, A. and Jin, B. (2009). Fate of pathogenic microorganisms and indicators in secondary activated sludge wastewater treatment plants. Journal of Environmental Management. 90, pp. 1442-1447.

Wetz, J.J., Lipp, E.K., Griffin, D.W., Lukasik, J., Wait, D., Sobsey, M.D. et al. (2004). Presence, infectivity, and stability of enteric viruses in seawater: relationship to marine water quality in the Florida Keys. Marine Pollution Bulliten. 48, pp. 698-704.

WHO,. (2015). WHO Global Action Plan to minimize poliovirus facility-associated risk after type-specific eradication of wild polioviruses and sequential cessation of oral polio vaccine use (GAPII). WHO http://www.polioeradication.org/Posteradication/Certification.aspx Last Accessed July 2015.

WHO,. (2015). Guidelines On Environmental Surveillance For Detection Of Polioviruses Working draft -March 2015. WHO, Dept of Vaccines and Biologicals; http://www.polioeradication.org/Portals/0/Document/Resources/GPLN_publications/GPLN_GuidelinesES_April2015.pdf last 
accessed 17-05-2015.

WHO,. (2014). Global Polio Eradication Initiative. Data and monitoring. Who http://www.polioeradication.org/dataandmonitoring.aspx. Last accessed July 2015.

WHO (2011). Guidelines for Drinking-water Quality 4th edition. WHO http://www.who.int/water_sanitation_health/publications/2011/dwq_guidelines/en/ Last accessed July 2015.

WHO,. (2006). WHO guidelines for the safe use of wastewater, excreta and greywater. 4, WHO (http://www.susana.org/en/resources/library/details/1004). Last Accessed July 2015.

WHO,. (2004). Polio Laboratory Manual 4th edition, 2004. WHO/IVB/04.10. WHO. doi: WHO/IVB/04.10.

WHO, UNICEF (2015). Progress on Drinking Water and Sanitation - 2015 update and MDG assessment. WHO/UNICEF http://www.who.int/water_sanitation_health/monitoring/en/: and http://weshare.unicef.org/C.aspx?VP3=SearchResult\&amp;ALID=2AM408T1QDOK last accessed July 2015.

Wigginton, K.R. and Kohn, T. (2012). Virus disinfection mechanisms: the role of virus composition, structure, and function. Current Opinion in Virology. 2, pp. 84-9. doi: 10.1016/j.coviro.2011.11.003.

Williams, J., Bahgat, M., May, E., Ford, M. and Butler, J. (1995). Mineralisation and Pathogen Removal in Gravel Bed Hydroponic Constructed Wetlands for Wastewater Treatment. Water Science and Technology. 32, pp. 49-58.

Williams, M.E. (2003). A Review of Wastewater Treatment by Reverse Osmosis. Williams Engineering Services Company, In c. , http://www.wescinc.com

https://www.google.co.il/url?sa=t\&amp;rct=j\&amp;q=\&amp;esrc=s\&amp;source=web\& $a m p ; \mathrm{cd}=1 \& a m p ; \mathrm{ved}=0 \mathrm{CB} 0 \mathrm{QFjAA}$ ahUKEwjXzuSHmpbHAhWSj9sKHXu5BQU\&amp;url=http\%3A\%2F\%2Fwww.wescinc.com\%2Ffiles\%2FRO_Apps.pdf\&amp; ei=Vz3EVZfHAZKf7gb7.

Willis, J. and Schafer, P. (2006). Advances In Thermophilic Anaerobic Digestion. Proceedings of the Water Environment Foundation. pp. 5378-5392.

Wong, K., Fong, T.T., Bibby, K. and Molina, M. (2012). Application of enteric viruses for fecal pollution source tracking in environmental waters. Environment International. 45, pp. 151-64. doi: 10.1016/j.envint.2012.02.009.

Wong, K., Onan, B.M. and Xagoraraki, I. (2010). Quantification of enteric viruses, pathogen indicators, and Salmonella bacteria in class B anaerobically digested biosolids by culture and molecular methods. Applied and Environmental Microbiology. 76, pp. 6441-8. doi: 10.1128/AEM.02685-09 AEM.02685-09 [pii].

Wyer, M.D., Fleisher, J.M., Gough, J., Kay, D. and,. (1995). An investigation into parametric relationships between enterovirus and fecal indicator organisms in the coastal waters of England and Wales. Wat Res. 29, pp. 1863-1868.

Wyn-Jones, A.P. and Sellwood, J. (1998). Review of methods for the isolation, concentration, identification and enumeration of enteroviruses. Project WW-11B. UK Water Industry Research Ltd.

Wyn-Jones, P. (2007). The detection of waterborne viruses. Elsevier. pp. 177-204.

Xagoraraki, I., Yin, Z. and Svambayev, Z. (2014). Fate of viruses in water systems. Journal of Environmental Engineering. 140, pp. 04014020.

Yahya, M.T., Straub, T.M. and Gerba, C.P. (1992). Inactivation of coliphage MS-2 and poliovirus by copper, silver, and chlorine. Can J Microbiol. 38, pp. 430-5.

Yates, M.V. (2002). Bitton G. Encyclopedia of environmental microbiology. pp. 3268-3276.

Yates, M.V. and Yates, S.R. (1988). Virus survival and transport in groundwater. Water Science and Technology. 20, pp. 301-307. 
Yates, M.V. (2002). Virus Survival in Soils. Encyclopedia of Environmental Microbiology.

Ye, X.Y., Ming, X., Zhang, Y.L., Xiao, W.Q., Huang, X.N., Cao, Y.G. et al. (2012). Real-time PCR detection of enteric viruses in source water and treated drinking water in Wuhan, China. Current Microbiology. 65, pp. 244-53. doi: 10.1007/s00284-012-0152-1.

Young, D.C. and Sharp, D.G. (1977). Poliovirus aggregates and their survival in water. Applied and Environmental Microbiology. 33, pp. 168-77.

Zhang, K. and Farahbakhsh, K. (2007). Removal of native coliphages and coliform bacteria from municipal wastewater by various wastewater treatment processes: implications to water reuse. Water Research. 41, pp. 2816-24. doi: 10.1016/j.watres.2007.03.010.

Zhang, M., Zhao, H., Yang, J., Jiang, S. and Cai, B. (2010). Detection and quantification of enteroviruses in coastal seawaters from Bohai Bay, Tianjin, China. Journal of Environmental Sciences. 22, pp. 150-154. doi: 10.1016/s1001-0742(09)60086-3.

Zhang, Q., He, X. and Yan, T. (2015). Differential Decay of Wastewater Bacteria and Change of Microbial Communities in Beach Sand and Seawater Microcosms. Environmental Science and Technology. 49, pp. 8531-40. doi: 10.1021/acs.est.5b01879.

Zheng, H., Lu, J., Zhang, Y., Yoshida, H., Guo, X., Liu, L. et al. (2013). Prevalence of Nonpolio Enteroviruses in the Sewage of Guangzhou City, China, from 2009 to 2012. Applied and Environmental Microbiology. 79, pp. 7679-7683. doi: 10.1128/aem.02058-13.

Zhu, F., Xu, W., Xia, J., Liang, Z., Liu, Y., Zhang, X. et al. (2014). Efficacy, safety, and immunogenicity of an enterovirus 71 vaccine in China. The New England Journal of Medicine. 370, pp. 818-28. doi: 10.1056/NEJMoa1304923.

Zuthi, M.F., Ngo, H.H. and Guo, W.S. (2012). Modelling bioprocesses and membrane fouling in membrane bioreactor (MBR): a review towards finding an integrated model framework. Bioresource Technology. 122, pp. 119-29. doi: 10.1016/j.biortech.2012.04.090 S0960-8524(12)00714-6 [pii]. 